\title{
Caustic Leaching of Hanford Tank S-110 Sludge
}

\author{
G. J. Lumetta \\ K. J. Carson \\ L. P. Darnell \\ L. R. Greenwood \\ F. V. Hoopes \\ R. L. Sell \\ S. I. Sinkov \\ C. Z. Soderquist \\ M. W. Urie \\ J. J. Wagner
}

October 2001

Prepared for the U.S. Department of Energy under Contract DE-AC06-76RL01830

This work is funded by the Office of Science and Technology, within the Department of Energy's Office of Environmental Management, under the Efficient Separations and Processing Crosscutting Program. 


\title{
Caustic Leaching of Hanford Tank S-110 Sludge
}

\author{
G. J. Lumetta \\ K. J. Carson \\ L. P. Darnell \\ L. R. Greenwood \\ F. V. Hoopes \\ R. L. Sell \\ S. I. Sinkov \\ C. Z. Soderquist \\ M.W. Urie \\ J. J. Wagner
}

October 2001

Prepared for

the U.S. Department of Energy

under Contract DE-AC06-76RL01830

This work is funded by the Office of Science and Technology, within the Department of Energy's Office of Environmental Management, under the Efficient Separations and Processing Crosscutting Program.

Pacific Northwest National Laboratory

Richland, Washington 99352 



\section{Summary}

This report describes the Hanford Tank S-110 sludge caustic leaching test conducted in FY 2001 at the Pacific Northwest National Laboratory. The data presented here can be used to develop the baseline and alternative flowsheets for pretreating Hanford tank sludge. The U.S. Department of Energy funded the work through the Efficient Separations and Processing Crosscutting Program (ESP; EM-50).

The S-110 sludge sample was first subjected to washing with dilute sodium hydroxide solution at ambient temperature. Following the dilute hydroxide washing, several aliquots of the washed solids were taken for leaching tests. The washed solids were subjected to leaching with 1,3 , or $5 \underline{\mathrm{M}} \mathrm{NaOH}$ at 60,80 , or $100^{\circ} \mathrm{C}$ for up to $168 \mathrm{~h}$. The leachates were sampled at $4,8,24,72$, and $168 \mathrm{~h}$. The leached solids were dried to constant mass at $105^{\circ} \mathrm{C}$ and then analyzed.

The work presented here indicates caustic leaching to be a very effective method of pretreating Hanford Tank S-110 sludge. Because of the predominance of boehmite in the water-insoluble S-110 solids, high caustic and temperature are required to sufficiently remove Al. It would also be necessary to leach for several days to realize the full benefits of caustic leaching. As expected, Al removal improves with increasing temperature, $\mathrm{NaOH}$ concentration, and leaching time. The $\mathrm{Cr}$ behavior parallels that of Al.

At a maximum of $0.5 \mathrm{wt} \% \mathrm{Cr}_{2} \mathrm{O}_{3}$ in the high-level waste form, the mass of immobilized high-level waste (IHLW) would be constrained by the Cr content of the leached S-110 solids. Nevertheless, an 80 to $90 \%$ reduction in IHLW mass from the S-110 solids should be readily achievable.

The results of this work underscore the need to continue process optimization studies. If subjected to the baseline leaching approach $\left(3 \mathrm{M} \mathrm{NaOH}, 80\right.$ to $90^{\circ} \mathrm{C}$, for $8 \mathrm{~h}$ ), only about $25 \%$ of the $\mathrm{Al}$ would be leached from the dilute hydroxide-washed S-110 solids. Clearly, this would not be sufficient to adequately reduce the IHLW mass. 



\section{Glossary}

\begin{tabular}{|c|c|}
\hline DOE & U.S. Department of Energy \\
\hline $\begin{array}{l}\text { ESP } \\
\text { ESW }\end{array}$ & $\begin{array}{l}\text { Efficient Separations and Processing Crosscutting Program } \\
\text { enhanced sludge washing }\end{array}$ \\
\hline GEA & gamma energy analysis \\
\hline $\begin{array}{l}\text { HDPE } \\
\text { HLW }\end{array}$ & $\begin{array}{l}\text { high density polyethylene } \\
\text { high-level waste }\end{array}$ \\
\hline $\begin{array}{l}\text { ICP/AES } \\
\text { IHLW } \\
\text { ILAW }\end{array}$ & $\begin{array}{l}\text { inductively coupled plasma/atomic emission spectroscopy } \\
\text { immobilized high level waste } \\
\text { immobilized low-activity waste }\end{array}$ \\
\hline $\begin{array}{l}\text { LAW } \\
\text { LLW }\end{array}$ & $\begin{array}{l}\text { low-activity waste } \\
\text { low-level waste }\end{array}$ \\
\hline $\mathrm{NRC}$ & U.S. Nuclear Regulatory Commission \\
\hline $\begin{array}{l}\text { PMP } \\
\text { PNNL } \\
\text { PP }\end{array}$ & $\begin{array}{l}\text { polymethylpentene } \\
\text { Pacific Northwest National Laboratory } \\
\text { polypropylene }\end{array}$ \\
\hline REDOX & REDOX process for Pu recovery \\
\hline TRU & transuranic elements \\
\hline $\mathrm{UV} / \mathrm{vis}$ & ultraviolet/visible \\
\hline WOL & ste Oxide Loading \\
\hline
\end{tabular}





\section{Acknowledgments}

This work was funded by the U.S. Department of Energy Office of Science and Technology through the Efficient Separations and Processing Crosscutting Program (ESP). The authors thank Jerry Harness and Jack Watson of the ESP and Phil McGinnis of the Tanks Focus Area. The authors also acknowledge Ted Pietrok and Marcus Glasper in the DOE Richland Operations Office.

The authors gratefully acknowledge W. C. Cosby and B. M. Rapko for reviewing this document. The authors also thank C. L. Blair, W. F. Bonner, P. A. Meyer, and M. Larson for their project-management support.

Pacific Northwest National Laboratory is operated by Battelle for the U.S. Department of Energy under Contract DE-AC06-76RL01830. 



\section{Contents}

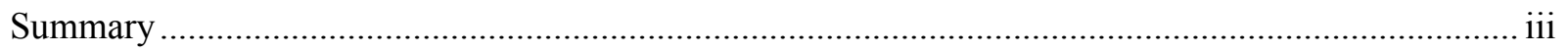

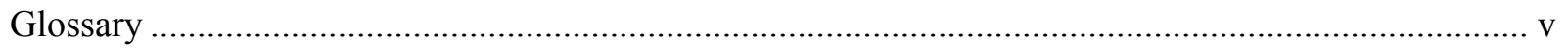

Acknowledgments................................................................................................................ vii

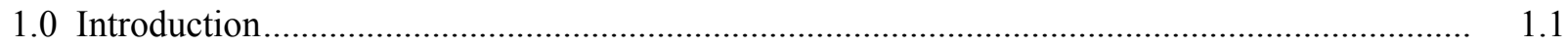

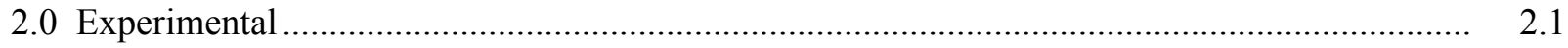

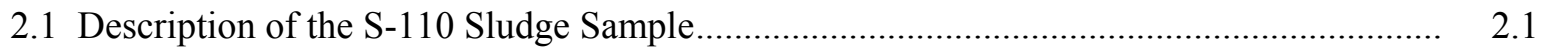

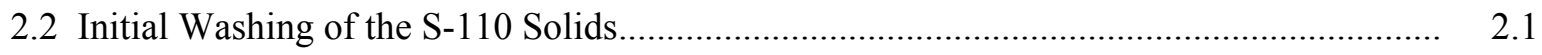

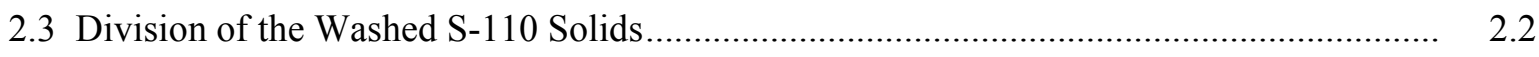

2.4 Caustic Leaching of the Washed S-110 Solids................................................................. 2.3

2.5 Determination of Hydroxide Concentration .................................................................... 2.4

2.6 Determination of Chromium(VI) Concentration .......................................................... 2.5

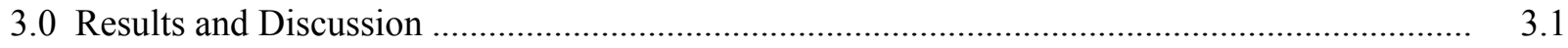

3.1 Aluminum Dissolution ...................................................................................

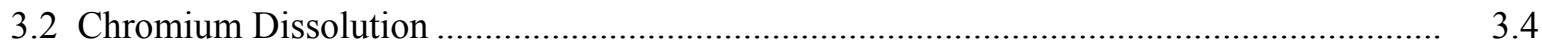

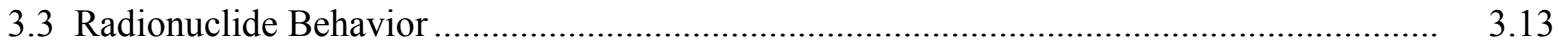

3.4 Impact of Leaching on Immobilized High-Level Waste Glass Mass .................................. $\quad 3.14$

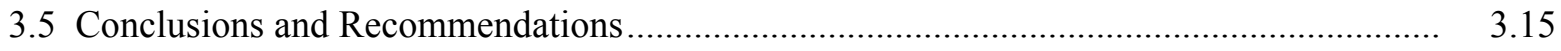

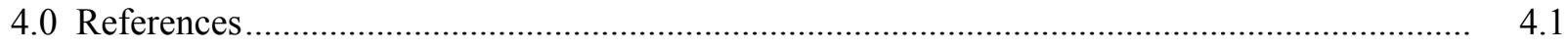

Appendix A: Solution Concentrations as a Function of Time …............................................. A.1

Appendix B: Leaching Results in Terms of Percent Component Removed ................................ B.1

Appendix C: Radionuclide Behavior ............................................................................. C.1 


\section{Figures}

3.1. Aluminum Concentration as a Function of Time During Leaching of S-110

Solids at $60^{\circ} \mathrm{C}$

3.2. Aluminum Concentration as a Function of Time During Leaching of S-110

Solids at $80^{\circ} \mathrm{C}$

3.3. Aluminum Concentration as a Function of Time During Leaching of S-110

Solids at $100^{\circ} \mathrm{C}$.

3.4. Aluminum Concentration and Removal as a Function of Time During

Leaching of S-110 Solids at $1 \mathrm{M} \mathrm{NaOH}$

3.5. Aluminum Concentration and Removal as a Function of Time During

Leaching of S-110 Solids at $3 \mathrm{M} \mathrm{NaOH}$

3.6. Aluminum Concentration and Removal as a Function of Time During Leaching of S-110 Solids at $5 \mathrm{M} \mathrm{NaOH}$.....

3.7. Chromium Concentration as a Function of Time During Leaching of S-110

Solids at $60^{\circ} \mathrm{C}$.

3.8. Chromium Concentration as a Function of Time During Leaching of S-110

Solids at $80^{\circ} \mathrm{C}$.

3.9. Chromium Concentration as a Function of Time During Leaching of S-110

Solids at $100^{\circ} \mathrm{C}$.

3.10. Chromium Concentration and Removal as a Function of Time During

Leaching of S-110 Solids at $1 \mathrm{M} \mathrm{NaOH}$

3.11. Chromium Concentration and Removal as a Function of Time During

Leaching of S-110 Solids at $3 \mathrm{M} \mathrm{NaOH}$.

3.12. Chromium Concentration and Removal as a Function of Time During

Leaching of S-110 Solids at $5 \mathrm{M} \mathrm{NaOH}$ 


\section{Tables}

2.1. Description of S-110 Sludge Composite

2.2. Composition of the Dilute Hydroxide-Washed S-110 Solids........................................... 2.2

2.3. Mass of Washed S-110 Solids in Each Leaching Aliquot .................................................... 2.3

2.4. Caustic Leaching Conditions.................................................................................. 2.4

2.5. Mass of the Leached S-110 Solids and the Mass Loss Achieved During Leaching............... $\quad 2.4$

2.6. Comparison of Measured $\mathrm{Cr}(\mathrm{VI})$ and Total Cr Concentrations ......................................... 2.5

3.1. Results of Dilute-Hydroxide Washing of the As-Received S-110 Sludge ........................... 3.1

3.2. Aluminum, Chromium, and Phosphorus Removal Achieved After One Week

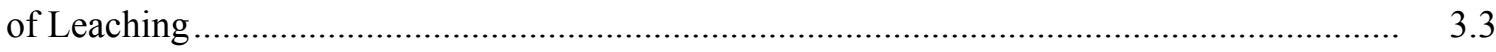

3.3. Estimated Concentrations of Waste-Derived Components in the IHLW Glass from S-110 Waste 



\subsection{Introduction}

Since 1990, the primary mission at the U.S. Department of Energy's Hanford Site has changed from producing plutonium to restoring the environment. Large volumes of high-level radioactive wastes (HLW), generated during past $\mathrm{Pu}$ production and other operations, are stored in underground tanks onsite. The current plan for remediating the Hanford tank farms consists of waste retrieval, pretreatment, treatment (immobilization), and disposal. The tank wastes will be partitioned into high-level and lowactivity fractions. The low-activity waste (LAW) will be processed to remove ${ }^{137} \mathrm{Cs}$ and ${ }^{99} \mathrm{Tc}$ (and ${ }^{90} \mathrm{Sr}$ and transuranic elements in selected cases), and then it will be immobilized in a glass matrix and disposed of by shallow burial onsite. The HLW will be immobilized in a borosilicate glass matrix; the resulting glass canisters will then be disposed of in a geologic repository (DOE/ORP 2001). Because of the expected high cost of HLW vitrification and geologic disposal, pretreatment processes will be implemented to reduce the volume of immobilized high-level waste (IHLW).

Dilute hydroxide washing is the minimum pretreatment that would be performed on Hanford tank sludges. This method simply involves mixing the sludge with dilute ( $0.1 \underline{\mathrm{M}}$ or less) $\mathrm{NaOH}$, then performing some sort of solid/liquid separation. This is meant to remove water-soluble sludge components (mainly sodium salts) from the HLW stream. Dilute hydroxide is used rather than water to maintain the ionic strength high enough that colloidal suspensions are avoided.

Caustic leaching (sometimes referred to as enhanced sludge washing or ESW) represents the baseline method for pretreating Hanford tank sludges. Caustic leaching is expected to remove a large fraction of the $\mathrm{Al}$, which is present in large quantities in Hanford tank sludges. The Al will be removed by converting aluminum oxides/hydroxides to sodium aluminate. For example, boehmite and gibbsite are dissolved according to the following equations (Weber 1982).

$$
\begin{gathered}
\mathrm{AlOOH}(\mathrm{s})+\mathrm{NaOH}(\mathrm{aq}) \rightarrow \mathrm{NaAlO}_{2}(\mathrm{aq})+\mathrm{H}_{2} \mathrm{O} \\
\mathrm{Al}(\mathrm{OH})_{3}(\mathrm{~s})+\mathrm{NaOH}(\mathrm{aq}) \rightarrow \mathrm{NaAlO}_{2}(\mathrm{aq})+2 \mathrm{H}_{2} \mathrm{O}
\end{gathered}
$$

A significant portion of the $\mathrm{P}$ is also expected to be removed from the sludge by the metathesis of water-insoluble metal phosphates to insoluble hydroxides and soluble $\mathrm{Na}_{3} \mathrm{PO}_{4}$. An example of this is shown for iron(III) phosphate in the following equation.

$$
\mathrm{FePO}_{4}(\mathrm{~s})+3 \mathrm{NaOH}(\mathrm{aq}) \rightarrow \mathrm{Fe}(\mathrm{OH})_{3}(\mathrm{~s})+\mathrm{Na}_{3} \mathrm{PO}_{4}(\mathrm{aq})
$$

Similar metathesis reactions can also occur for insoluble sulfate salts, allowing the removal of sulfate from the HLW stream.

Based on its known amphoteric behavior (Rai et al. 1987), Cr(III) was expected to be removed by caustic leaching according to the following equation:

$$
\mathrm{Cr}(\mathrm{OH})_{3}(\mathrm{~s})+\mathrm{NaOH}(\mathrm{aq}) \rightarrow \mathrm{Na}\left[\mathrm{Cr}(\mathrm{OH})_{4}\right](\mathrm{aq})
$$


However, studies conducted at the Pacific Northwest National Laboratory (PNNL) have suggested that the behavior of $\mathrm{Cr}$ in the caustic leaching process is more complex (Lumetta et al. 1997).

Results of previous studies of the baseline Hanford sludge-washing and caustic-leaching process have been reported (Lumetta and Rapko 1994; Rapko et al. 1995, Lumetta et al. 1996a and 1996b, 1997, and 1998; Temer and Villarreal 1995, 1996, and 1997). In the initial work, a standard set of test conditions was examined for each sludge. In FY 1998, the focus of the testing effort shifted to performing parametric tests on selected sludge samples (Lumetta et al. 1998). The purpose of the parametric tests is to provide data that process engineers can use to optimize process flowsheets for specific waste types. The parameters being considered are time, temperature, and caustic $(\mathrm{NaOH})$ concentration. This report describes the results of a parametric caustic-leaching tests performed on sludge from Hanford Tank $\mathrm{S}-110$. This tank contains primarily waste from the Reduction Oxidation (REDOX) process for $\mathrm{Pu}$ recovery, but also contains evaporator bottoms and a mixture of other miscellaneous wastes (Hill et al. 1995). 


\subsection{Experimental}

\subsection{Description of the S-110 Sludge Sample}

The S-110 sludge sample used was a composite of segments from two different core samples (Table 2.1). The composite sample was prepared at the Hanford 222-S Laboratory and shipped to PNNL in March 2001.

Table 2.1. Description of S-110 Sludge Composite

\begin{tabular}{|l|c|c|c|c|c||}
\hline $\begin{array}{c}\text { Sample } \\
\text { ID }^{(\mathbf{a})}\end{array}$ & $\begin{array}{c}\text { Core } \\
\text { No. }\end{array}$ & $\begin{array}{c}\text { Core } \\
\text { Date }\end{array}$ & $\begin{array}{c}\text { Tank } \\
\text { Riser }\end{array}$ & $\begin{array}{c}\text { Segment } \\
\text { No. }\end{array}$ & $\begin{array}{c}\text { Amount } \\
\text { Added, }\end{array}$ \\
\hline S98T001898 & 240 & May 1998 & 14 & 9 & 30.0 \\
\hline S98T001904 & 240 & May 1998 & 14 & 10 & 30.7 \\
\hline S98T001978 & 241 & June 1998 & 6 & 2 & 30.2 \\
\hline S98T001984 & 241 & June 1998 & 6 & 3 & 30.0 \\
\hline S98T001994 & 241 & June 1998 & 6 & 4 & 30.1 \\
\hline S98T002014 & 241 & June 1998 & 6 & 7 & 30.0 \\
\hline S98T002026 & 241 & June 1998 & 6 & 8 & 30.1 \\
\hline & \multicolumn{5}{|c|}{ Net Mass, g: } \\
\hline
\end{tabular}

\subsection{Initial Washing of the S-110 Solids}

The 211-g S-110 composite sample was transferred to a 500-mL high-density polyethylene (HDPE) bottle by a combination of scooping with a spatula and sluicing with $0.01 \mathrm{M} \mathrm{NaOH}$. The S-110 sludge was very sticky with a consistency like peanut butter. Dilute $(0.01 \mathrm{M}) \mathrm{NaOH}$ solution was added to yield a total volume of $400 \mathrm{~mL}$, and then the mixture was shaken overnight. The mixture was allowed to stand for $2 \mathrm{~h}$, after which time there was no indication of solids settling. The wash slurry was split between two centrifuge bottles and was centrifuged for $20 \mathrm{~min}$ (at $\sim 1200 \mathrm{G}$ ). The wash liquor was decanted from each centrifuge bottle and saved. The centrifuged solids were transferred back into the $500-\mathrm{mL}$ bottle, and the process was repeated. The third and final wash was conducted in the centrifuge bottles. Dilute $(0.01 \mathrm{M})$ $\mathrm{NaOH}$ solution was added to each centrifuge bottle containing the centrifuged solids to yield a total volume of $\sim 175 \mathrm{~mL}$ in each bottle. The bottles were shaken overnight and then centrifuged. The wash liquor was decanted and combined with the previous wash liquors. The total mass of the combined wash solution was $764.7 \mathrm{~g}$.

The washed solids were transferred to a 1-L HDPE bottle by slurrying with deionized water. The slurry was made to $\sim 1 \mathrm{~L}$ with deionized water. The mass of this slurry was $976.6 \mathrm{~g}$. The slurry was mixed with a magnetic stirrer, and two 2-g aliquots were taken for analysis. Two additional $0.5-\mathrm{mL}$ aliquots of the washed solids slurry were taken for potential solids characterization. The two 2-g aliquots were dried to constant weight at $105^{\circ} \mathrm{C}$ to determine the solids composition of the slurry. The slurry contained $7.72 \mathrm{wt} \%$ solids, which translated to a total of $74.96 \mathrm{~g}$ of washed solids. The two dried aliquots of washed solids were analyzed by inductively coupled plasma-atomic emission spectroscopy (ICP-AES), gamma energy analysis (GEA), and for total alpha and total beta activity (Table 2.2). 
Table 2.2. Composition of the Dilute Hydroxide-Washed S-110 Solids

\begin{tabular}{|c|c|}
\hline Component & Concentration, $\mu \mathrm{g} / \mathrm{g}$ \\
\hline $\mathrm{Al}$ & 325000 \\
\hline B & [135] \\
\hline $\mathrm{Ba}$ & [110] \\
\hline $\mathrm{Bi}$ & 1365 \\
\hline $\mathrm{Ca}$ & [1200] \\
\hline $\mathrm{Cd}$ & {$[60]$} \\
\hline $\mathrm{Cr}$ & 23050 \\
\hline $\mathrm{Cu}$ & {$[82]$} \\
\hline $\mathrm{Fe}$ & 14150 \\
\hline $\mathrm{La}$ & [160] \\
\hline $\mathrm{Mg}$ & [380] \\
\hline $\mathrm{Mn}$ & 5305 \\
\hline $\mathrm{Na}$ & 30000 \\
\hline $\mathrm{Nd}$ & [345] \\
\hline $\mathrm{P}$ & 1415 \\
\hline $\mathrm{Pb}$ & [595] \\
\hline $\mathrm{Si}$ & [5500] \\
\hline $\mathrm{Sr}$ & 1240 \\
\hline $\mathrm{Ti}$ & {$[58]$} \\
\hline $\mathrm{U}$ & [23500] \\
\hline $\mathrm{Zn}$ & [225] \\
\hline $\mathrm{Zr}$ & [135] \\
\hline Component & Concentration, $\mu \mathrm{Ci} / \mathrm{g}$ \\
\hline Total Alpha $^{(\mathrm{b})}$ & $1.8 \mathrm{E}+00$ \\
\hline Total Beta & $1.4 \mathrm{E}+03$ \\
\hline${ }^{137} \mathrm{Cs}^{(\mathrm{b})}$ & $3.1 \mathrm{E}+01$ \\
\hline
\end{tabular}

(a) Experimental uncertainties are 15\%, except for values given in brackets. Values given in brackets are within 10 times the detection limit, and the uncertainties for these values are greater than $15 \%$.

(b) The process blank indicated relatively high total alpha $(0.35 \mu \mathrm{Ci} / \mathrm{g})$ and ${ }^{137} \mathrm{Cs}(7.61 \mu \mathrm{Ci} / \mathrm{g})$ concentrations. So the reported values should be used with some caution.

\subsection{Division of the Washed S-110 Solids}

After having stood for 2 to 3 weeks, it was impossible to adequately stir the slurry of washed solids with the magnetic stirrer. A mechanical stirrer was used instead to homogenize the slurry. Nine aliquots, 
nominally $15 \mathrm{~g}$ each, were transferred to $125-\mathrm{mL}$ polypropylene (PP) bottles using a large (23-mL capacity) disposable polyethylene pipette. Table 2.3 lists the bottle labels, the mass of each aliquot, and the amount of solids in each aliquot, based on $7.72 \mathrm{wt} \%$ solids in the slurry.

Table 2.3. Mass of Washed S-110 Solids in Each Leaching Aliquot

\begin{tabular}{|c|c|c|}
\hline Bottle ID & Mass Slurry, $\mathbf{g}$ & Mass Solids, $\mathbf{g}$ \\
\hline S110-60-1 & 15.4 & 1.189 \\
\hline S110-60-3 & 15.2 & 1.173 \\
\hline S110-60-5 & 15.0 & 1.158 \\
\hline S110-80-1 & 15.1 & 1.166 \\
\hline S110-80-3 & 15.0 & 1.158 \\
\hline S110-80-5 & 15.1 & 1.166 \\
\hline S110-100-1 & 15.0 & 1.158 \\
\hline S110-100-3 & 15.2 & 1.173 \\
\hline S110-100-5 & 15.1 & 1.166 \\
\hline
\end{tabular}

\subsection{Caustic Leaching of the Washed S-110 Solids}

Table 2.4 summarizes the leaching conditions for each aliquot of washed S-110 solids. A slight excess $(0.1 \mathrm{M})$ of $\mathrm{NaOH}$ was added to each reaction vessel to compensate for hydroxide ion consumed in chemical reactions. The aluminum heating block was preheated to the desired temperature. Sodium hydroxide solution $(10 \mathrm{M})$ was added to each aliquot of washed S-110 solids in the following amounts: $11.0 \mathrm{~mL}$ to yield $1 \mathrm{M} \mathrm{NaOH}, 31.0 \mathrm{~mL}$ to yield $3 \mathrm{M} \mathrm{NaOH}$, and $51 \mathrm{~mL}$ to yield $5 \mathrm{M} \mathrm{NaOH}$. The leaching mixtures were then diluted to $100 \mathrm{~mL}$ with deionized water. The ratio of $\sim 80 \mathrm{~mL}$ solution per gram of washed S-110 solids was chosen so as to avoid Al solubility limits in any of the test samples.

It was discovered that the 125-mL HDPE bottles containing the nine aliquots would not fit in the aluminum heating block when at temperature. For this reason, it was necessary to transfer the leaching slurries to 125-mL polymethylpentene (PMP) bottles. In all cases, the transfer of the slurry was essentially quantitative, with $\geq 99.8 \%$ of the slurry transferred.

The liquid level was marked on each reaction vessel, and each vessel was closed with a cap equipped with a tube-condenser. The leaching mixtures were mixed at temperature with a magnetic stirrer.

Evaporation was minimal during the course of the experiment; occasionally, deionized water was added to bring the liquid level up to its original position. The leachates were sampled at intervals of 4, 8, 24, 72, and $168 \mathrm{~h}$. For each sampling, the stirrer was stopped, and the solids were settled at temperature. The transfer pipette and the syringe filter assembly $(0.45-\mu \mathrm{m}$ nylon membrane $)$ were preheated by inserting in a boiling water bath. These were then used to filter $\sim 1 \mathrm{~mL}$ of the leachate solution. A $0.5-\mathrm{mL}$ aliquot of the filtered solution was immediately acidified with $15 \mathrm{~mL}$ of $0.3 \mathrm{M} \mathrm{HNO}_{3}$. The remaining filtered solution was added back to the reaction vessel, and the leaching was continued. After $168 \mathrm{~h}$, additional samples were taken for titrimetric (diluted into deionized water) analysis and $\mathrm{Cr}(\mathrm{VI})$ analysis by $\mathrm{UV}$ spectrophotometry (diluted into $0.1 \mathrm{M} \mathrm{NaOH}$ ). 
At the conclusion of the test, the reaction vessels were centrifuged for $5 \min (\sim 1200 \mathrm{G})$ immediately after removing from the heating block. The leachate was decanted and saved. The leached solids were washed thrice with $30-\mathrm{mL}$ portions of $0.01 \mathrm{M} \mathrm{NaOH}$ and then were dried at $105^{\circ} \mathrm{C}$. Table 2.5 gives the weights of the leached solids and the weight reductions achieved after leaching for $168 \mathrm{~h}$.

Table 2.4. Caustic Leaching Conditions

\begin{tabular}{||c|c|c||c||}
\cline { 3 - 3 } \multicolumn{1}{c|}{} & \multicolumn{2}{c|}{$[\mathbf{N a O H}], \mathbf{M}$} & \multicolumn{1}{c||}{} \\
\hline Bottle ID & Target & Measured & Temperature, ${ }^{\circ} \mathbf{C}$ \\
\hline S110-60-1 & 1 & 1.0 & 60 \\
\hline S110-60-3 & 3 & 2.8 & 60 \\
\hline S110-60-5 & 5 & 4.8 & 60 \\
\hline S110-80-1 & 1 & 0.9 & 80 \\
\hline S110-80-3 & 3 & 2.7 & 80 \\
\hline S110-80-5 & 5 & 4.6 & 80 \\
\hline S110-100-1 & 1 & 0.8 & 100 \\
\hline S110-100-3 & 3 & 2.7 & 100 \\
\hline S110-100-5 & 5 & 4.6 & 100 \\
\hline \hline
\end{tabular}

Table 2.5. Mass of the Leached S- 110 Solids and the Mass Loss Achieved During Leaching

\begin{tabular}{|c|c|c|}
\hline Bottle ID & Mass of Leached Solids, g & Mass Loss, \% \\
\hline S110-60-1 & 0.799 & 33 \\
\hline S110-60-3 & 0.671 & 43 \\
\hline S110-60-5 & 0.598 & 48 \\
\hline S110-80-1 & 0.428 & 63 \\
\hline S110-80-3 & 0.207 & 82 \\
\hline S110-80-5 & 0.143 & 88 \\
\hline S110-100-1 & 0.210 & 82 \\
\hline S110-100-3 & 0.107 & 91 \\
\hline S110-100-5 & 0.099 & 92 \\
\hline
\end{tabular}

\subsection{Determination of Hydroxide Concentration}

The free hydroxide concentration in the S-110 caustic leaching solutions was determined by titration with standard $\mathrm{HCl}$. Initially, aliquots of the leaching solutions were diluted with deionized water and titrated directly with $\mathrm{HCl}$. This gave very erratic results, which was believed to be caused by varying amounts of carbonate in the samples. Accordingly, $\mathrm{Ca}\left(\mathrm{NO}_{3}\right)_{2}$ was added to precipitate $\mathrm{CaCO}_{3}$ before performing the titration. Aliquots of the leaching solution $(0.5 \mathrm{~mL}$ for $1 \mathrm{M} \mathrm{NaOH}, 0.15 \mathrm{~mL}$ for $3 \mathrm{M}$ $\mathrm{NaOH}$, or $0.1 \mathrm{~mL}$ for $5 \mathrm{M} \mathrm{NaOH}$ ) were diluted into $10 \mathrm{~mL}$ of deionized water. To these analyte solutions was added $0.1 \mathrm{~mL}$ of $2 \mathrm{M} \mathrm{Ca}\left(\mathrm{NO}_{3}\right)_{2}$. The resulting solutions were then titrated with $0.1 \mathrm{M} \mathrm{HCl}$. The titration was conducted using a Mettler DL-21 automatic titrator equipped with a combination Ross ${ }^{\circledR}$ Electrode (ATI Orion, Boston, Massachusetts). Table 2.4 presents the measured free hydroxide concentrations. 


\subsection{Determination of Chromium(VI) Concentration}

The $\mathrm{CrO}_{4}{ }^{2-}$ concentration in the leaching solutions (after 1 week of leaching) was determined by ultraviolet/visible (UV/vis) spectrophotometry. A calibration curve was generated by measuring the spectra of standard $\mathrm{CrO}_{4}{ }^{2-}$ solutions (in $0.1 \mathrm{M} \mathrm{NaOH}$ ). The absorption at $372 \mathrm{~nm}$ was used. The leaching solutions were diluted with $0.1 \mathrm{M} \mathrm{NaOH}$ as needed, and the absorption was measured at $372 \mathrm{~nm}$. The $\mathrm{CrO}_{4}{ }^{2-}$ concentrations were calculated from the measured absorbance and the calibration curve. Table 2.6 compares the measured $\mathrm{CrO}_{4}{ }^{2-}$ values to the total $\mathrm{Cr}$ concentrations determined by ICP-AES. In all cases, the $\mathrm{Cr}(\mathrm{VI})$ and total $\mathrm{Cr}$ concentrations were the same within experimental uncertainty, although the total $\mathrm{Cr}$ concentrations were consistently greater than the $\mathrm{Cr}(\mathrm{VI})$ concentrations, which might suggest that some Cr(III) was present.

Table 2.6. Comparison of Measured $\mathrm{Cr}(\mathrm{VI})$ and Total Cr Concentrations

\begin{tabular}{||c|c|c||}
\cline { 2 - 3 } \multicolumn{1}{c|}{} & \multicolumn{2}{c|}{ Concentration, $\boldsymbol{\mu g} / \mathbf{g}$} \\
\hline Solution & Cr(VI) & Total $\mathbf{~ r ~}$ \\
\hline $1 \mathrm{M} \mathrm{NaOH}$ at $60^{\circ} \mathrm{C}$ & 144 & 154 \\
\hline $3 \mathrm{M} \mathrm{NaOH}$ at $60^{\circ} \mathrm{C}$ & 190 & 199 \\
\hline $5 \mathrm{M} \mathrm{NaOH}$ at $60^{\circ} \mathrm{C}$ & 207 & 217 \\
\hline $1 \mathrm{M} \mathrm{NaOH}$ at $80^{\circ} \mathrm{C}$ & 226 & 237 \\
\hline $3 \mathrm{M} \mathrm{NaOH}$ at $80^{\circ} \mathrm{C}$ & 236 & 251 \\
\hline $5 \mathrm{M} \mathrm{NaOH}$ at $80^{\circ} \mathrm{C}$ & 241 & 234 \\
\hline $1 \mathrm{M} \mathrm{NaOH}$ at $100^{\circ} \mathrm{C}$ & 258 & 265 \\
\hline $3 \mathrm{M} \mathrm{NaOH}$ at $100^{\circ} \mathrm{C}$ & 256 & 265 \\
\hline $5 \mathrm{M} \mathrm{NaOH}$ at $100^{\circ} \mathrm{C}$ & 245 & 255 \\
\hline
\end{tabular}





\subsection{Results and Discussion}

Table 3.1 presents the behavior of the various S-110 sludge components during washing of the asreceived $\mathrm{S}-110$ sludge sample with $0.01 \mathrm{M} \mathrm{NaOH}$. Besides $\mathrm{Na}, \mathrm{Al}$ is the dominant element present in the S-110 sludge. Dilute hydroxide washing is ineffectual at removing Al with only $4 \%$ reporting to the washing solution. Likewise, $\mathrm{Cr}$ removal is poor with only $17 \%$ of the total $\mathrm{Cr}$ removed by dilute hydroxide washing. In contrast, $\sim 70 \%$ of the $\mathrm{P}$ is removed by dilute hydroxide washing, suggesting that most of the $\mathrm{P}$ is present in the S-110 sludge as water-soluble phosphate salts. As expected, Na is largely removed by dilute hydroxide washing.

Appendix A presents the concentrations of the various S-110 sludge components in the leaching solutions as a function of time, as well as the concentrations in the final washing solutions. Appendix B presents detailed results of the S-110 leaching test in terms of the concentration and mass of each component in the 1) leaching solution (after one week), 2) post-leach washing solution, and 3) the leached solids. Also presented in Appendix B is the concentration of each component in the water-washed solids calculated by summing the mass of each component in the leaching and washing solutions and the residual solids then dividing by the amount of washed solids used in the test. The concentrations determined in this manner are compared to those obtained by direct analysis of the washed solids. Mass recoveries obtained were generally within $15 \%$ for the major sludge components (i.e., $\mathrm{Al}, \mathrm{Cr}, \mathrm{Fe}, \mathrm{Mn}, \mathrm{P}$, and Sr). Uranium was also a significant component of the sludge. The mass balance for $U$ was generally low (but within 20\%), probably because of the relative insensitivity of ICP-AES to U analysis.

Table 3.2 summarizes the removal achieved for the important sludge components $\mathrm{Al}, \mathrm{Cr}$, and $\mathrm{P}$ by leaching the washed S-110 solids with $\mathrm{NaOH}$ for one week. The removal of these elements parallels the mass losses listed in Table 2.4. That is, the removals of $\mathrm{Al}, \mathrm{Cr}$, and $\mathrm{P}$ increase with increasing temperature or increasing $\mathrm{NaOH}$ concentration. A more detailed discussion of $\mathrm{Al}$ and $\mathrm{Cr}$ dissolution is given in the following sections. ${ }^{(a)}$

Table 3.1. Results of Dilute-Hydroxide Washing of the As-Received S-110 Sludge

\begin{tabular}{|c|c|c|c|c|c|c|}
\hline & \multicolumn{2}{|c|}{ Initial Washing Solution } & \multicolumn{2}{|c|}{ Washed Solids } & & \\
\hline & $\begin{array}{l}\text { Solution } \\
\text { Mass, } \mathrm{g}\end{array}$ & 764.7 & $\begin{array}{c}\text { Solids } \\
\text { Mass, } \mathbf{g}\end{array}$ & 74.96 & & \\
\hline Component & Conc. $\mu \mathrm{g} / \mathrm{g}$ & Mass, $\mu \mathrm{g}$ & Conc. $\mu \mathrm{g} / \mathrm{g}$ & Mass, $\mu \mathrm{g}$ & Total Mass, $\mu \mathrm{g}$ & Removed, \% \\
\hline \multicolumn{7}{|l|}{$\mathrm{Ag}$} \\
\hline $\mathrm{Al}$ & 1410 & 1077863 & 325000 & 24362000 & 25439863 & $4 \%$ \\
\hline \multicolumn{7}{|l|}{ As } \\
\hline $\mathrm{B}$ & & & {$[135]$} & [10120] & 10120 & (b) \\
\hline $\mathrm{Ba}$ & & & {$[110]$} & 8246 & 8246 & (b) \\
\hline \multicolumn{7}{|l|}{$\mathrm{Be}$} \\
\hline $\mathrm{Bi}$ & & & 1365 & 102320 & 102320 & (b) \\
\hline $\mathrm{Ca}$ & & & [1200] & [89952] & 89952 & (b) \\
\hline
\end{tabular}

(a) A detailed discussion of phosphorus removal is not presented because the removal of this element is relatively independent of hydroxide concentration and temperature under the conditions examined, and its concentration in the S-110 solids is not great enough to cause concern. 
Table 3.1 (Contd)

\begin{tabular}{|c|c|c|c|c|c|c|}
\hline & \multicolumn{2}{|c|}{ Initial Washing Solution } & \multicolumn{2}{|c|}{ "Washed Solids } & & \\
\hline & \multirow{2}{*}{$\begin{array}{c}\begin{array}{c}\text { Solution } \\
\text { Mass, } \mathrm{g}\end{array} \\
\text { Conc. } \mu \mathrm{g} / \mathrm{g} \\
\end{array}$} & \multirow{2}{*}{$\begin{array}{c}764.7 \\
\text { Mass, } \mu \mathrm{g}\end{array}$} & \multirow{2}{*}{$\begin{array}{c}\begin{array}{c}\text { Solids } \\
\text { Mass, } \mathrm{g}\end{array} \\
\text { Conc. } \mu \mathrm{g} / \mathrm{g}\end{array}$} & \multirow{2}{*}{$\begin{array}{c}74.96 \\
\text { Mass, } \mu \mathrm{g}\end{array}$} & & \\
\hline Component & & & & & Total Mass, $\mu \mathrm{g}$ & Removed, \% \\
\hline $\mathrm{Cd}$ & & & [60] & [4498] & 4498 & (b) \\
\hline \multicolumn{7}{|l|}{$\mathrm{Ce}$} \\
\hline \multicolumn{7}{|l|}{ Co } \\
\hline $\mathrm{Cr}$ & 448 & 342294 & 23050 & 1727828 & 2070122 & $17 \%$ \\
\hline $\mathrm{Cu}$ & & & {$[82]$} & [6147] & 6147 & (b) \\
\hline \multicolumn{7}{|l|}{ Dy } \\
\hline \multicolumn{7}{|l|}{$\mathrm{Eu}$} \\
\hline $\mathrm{Fe}$ & {$[0.6]$} & 452 & 14150 & 1060684 & 1061136 & $0.04 \%$ \\
\hline K & [124] & 94677 & N/A & N/A & N/A & N/A \\
\hline $\mathrm{La}$ & & & {$[160]$} & [11994] & 11994 & (b) \\
\hline \multicolumn{7}{|l|}{$\mathrm{Li}$} \\
\hline $\mathrm{Mg}$ & & & {$[380]$} & [28485] & 28485 & (b) \\
\hline $\mathrm{Mn}$ & & & 5305 & 397663 & 397663 & (b) \\
\hline Mo & 5 & 3671 & & & 3761 & $100 \%$ \\
\hline $\mathrm{Na}$ & 27381 & 20938214 & 30000 & 2248800 & 23187014 & $91 \%{ }^{(\mathrm{c})}$ \\
\hline $\mathrm{Nd}$ & & & {$[345]$} & [25861] & 25861 & (b) \\
\hline $\mathrm{Ni}$ & & & $\mathrm{N} / \mathrm{A}$ & $\mathrm{N} / \mathrm{A}$ & $\mathrm{N} / \mathrm{A}$ & $\mathrm{N} / \mathrm{A}$ \\
\hline $\mathrm{P}$ & 356 & 272379 & 1415 & [106068] & 378447 & $72 \%$ \\
\hline $\mathrm{Pb}$ & & & [595] & [44601] & 44601 & (b) \\
\hline \multicolumn{7}{|l|}{$\mathrm{Pd}$} \\
\hline \multicolumn{7}{|l|}{$\mathrm{Rh}$} \\
\hline \multicolumn{7}{|l|}{$\mathrm{Ru}$} \\
\hline \multicolumn{7}{|l|}{$\mathrm{Sb}$} \\
\hline \multicolumn{7}{|l|}{$\mathrm{Se}$} \\
\hline $\mathrm{Si}$ & 28 & 21594 & [5500] & [412280] & 433874 & $5 \%$ \\
\hline \multicolumn{7}{|l|}{$\mathrm{Sn}$} \\
\hline $\mathrm{Sr}$ & & & 1240 & 92950 & 92950 & (b) \\
\hline \multicolumn{7}{|l|}{$\mathrm{Te}$} \\
\hline \multicolumn{7}{|l|}{ Th } \\
\hline $\mathrm{Ti}$ & & & [58] & [4348] & 4348 & (b) \\
\hline \multicolumn{7}{|l|}{$\mathrm{Tl}$} \\
\hline $\mathrm{U}$ & & & [23500] & 1761560 & 1761560 & (b) \\
\hline \multicolumn{7}{|l|}{$\mathrm{W}$} \\
\hline \multicolumn{7}{|l|}{$\mathrm{Y}$} \\
\hline $\mathrm{Zn}$ & & & [225] & [16866] & 16866 & (b) \\
\hline $\mathrm{Zr}$ & & & [135] & 10120 & 10120 & (b) \\
\hline
\end{tabular}

(a) Analyte was below detection limit if left blank. Experimental uncertainties are 15\%, except for values given in brackets. Values given in brackets are within 10 times the detection limit and the uncertainties for these values are greater than $15 \%$.

(b) No detectable removal.

(c) Not corrected for $\mathrm{Na}$ added as $\mathrm{NaOH}$ in washing solution. 
Table 3.2. Aluminum, Chromium, and Phosphorus Removal Achieved After One Week of Leaching

\begin{tabular}{|r|c|c|c|c||}
\cline { 3 - 5 } \multicolumn{2}{c|}{} & \multicolumn{4}{c|}{ Removed, \% } \\
\hline \hline $\mathbf{T},{ }^{\circ} \mathbf{C}$ & {$[\mathbf{N a O H}], \mathbf{M}$} & $\mathbf{A l}$ & $\mathbf{C r}$ & $\mathbf{P}$ \\
\hline 60 & 1.0 & 39 & 49 & 90 \\
\hline 60 & 2.8 & 47 & 70 & 92 \\
\hline 60 & 4.8 & 50 & 81 & 94 \\
\hline 80 & 0.9 & 69 & 78 & 92 \\
\hline 80 & 2.7 & 91 & 89 & 97 \\
\hline 80 & 4.6 & 96 & 90 & 99 \\
\hline 100 & 0.8 & 91 & 87 & 83 \\
\hline 100 & 2.7 & 100 & 91 & 95 \\
\hline 100 & 4.5 & 100 & 93 & 99 \\
\hline
\end{tabular}

\subsection{Aluminum Dissolution}

Figures 3.1, 3.2, and 3.3 illustrate the $\mathrm{Al}$ dissolution at 60,80 , and $100^{\circ} \mathrm{C}$, respectively. At $60^{\circ} \mathrm{C}$, the dissolution of Al was similar at the three hydroxide concentrations examined. There was a fairly rapid (within $8 \mathrm{~h}$ ) rise in $\mathrm{Al}$ concentration to about $700 \mu \mathrm{g} / \mathrm{g}$, followed by a gradual increase to about $1,800 \mu \mathrm{g} / \mathrm{g}$ after $168 \mathrm{~h}$ of leaching. The $\mathrm{Al}$ concentration did not appear to reach a steady value after $168 \mathrm{~h}$ of leaching at $60^{\circ} \mathrm{C}$. The initial rapid rise in $\mathrm{Al}$ concentration was probably due to dissolution of gibbsite. The more gradual increase in $\mathrm{Al}$ concentration beyond $8 \mathrm{~h}$ can be attributed to dissolution of boehmite, which is known to dissolve more slowly than gibbsite. X-ray diffraction analysis of the waterwashed S-110 solids indicated that the crystalline forms of Al in the solids consisted of 10 to $20 \%$ gibbsite and 80 to $90 \%$ boehmite.

At $80^{\circ} \mathrm{C}$, Al dissolution was similar in 3 and $5 \mathrm{M} \mathrm{NaOH}$, but $\mathrm{Al}$ dissolved to a lesser extent in $1 \mathrm{M} \mathrm{NaOH}$. It is not clear whether the $\mathrm{Al}$ concentration reached a constant value after $168 \mathrm{~h}$ of leaching at $80^{\circ} \mathrm{C}$. On the other hand, a constant $\mathrm{Al}$ concentration was reached after leaching for $72 \mathrm{~h}$ at $100^{\circ} \mathrm{C}$ in 3 and $5 \mathrm{M} \mathrm{NaOH}$. Aluminum dissolution was somewhat slower for $1 \mathrm{M} \mathrm{NaOH}$ at $100^{\circ} \mathrm{C}$, but reached the same end state (approximately $4000 \mu \mathrm{g} / \mathrm{g}$ ) as the 3 and $5 \mathrm{M}$ cases after leaching for $168 \mathrm{~h}$.

Figures 3.4, 3.5, and 3.6 illustrate the $\mathrm{Al}$ dissolution at 1, 3, and $5 \mathrm{M} \mathrm{NaOH}$, respectively. The data are presented in terms of both the $\mathrm{Al}$ concentration and the percentage of $\mathrm{Al}$ removed as a function of time. These figures clearly illustrate increased Al dissolution with increasing temperature. They also indicate that various conditions can be chosen to reach the same level of Al removal. For example, leaching the S-110 sludge with $1 \mathrm{M} \mathrm{NaOH}$ at $100^{\circ} \mathrm{C}$ for 1 week removes approximately the same amount of $\mathrm{Al}$ as leaching with $3 \mathrm{M} \mathrm{NaOH}$ at $100^{\circ} \mathrm{C}$ for 3 days. One striking feature of these data is that, in terms of $\mathrm{Al}$ dissolution, there is no significant advantage in using $5 \mathrm{M} \mathrm{NaOH}$ instead of $3 \mathrm{M} \mathrm{NaOH}$. However, there may be an advantage in using $5 \mathrm{M} \mathrm{NaOH}$ in terms of solution stability. 
The Al solubilities with respect to Gibbsite in 1,3 , and $5 \mathrm{M} \mathrm{NaOH}$ at $25^{\circ} \mathrm{C}$ are approximately 1818 , 5885 , and $11445 \mu \mathrm{g} / \mathrm{g}$ solution, respectively. ${ }^{(a)}$ Based on this, only the leachates obtained by leaching with $1 \mathrm{M} \mathrm{NaOH}$ at 80 and $100^{\circ} \mathrm{C}$ would be supersaturated when allowed to cool to $25^{\circ} \mathrm{C}$. However, the $\mathrm{Al}$ solubility in $1 \mathrm{M} \mathrm{NaOH}$ at $60^{\circ} \mathrm{C}$ is approximately $4675 \mu \mathrm{g} / \mathrm{g}$ solution. As the Al solubility increases with increasing temperature and $\mathrm{NaOH}$ concentration, this can be viewed as the minimum solubility for the leaching solutions at temperature. Comparison of this value to the measured Al concentrations confirms that in no case was $\mathrm{Al}$ removal limited by the $\mathrm{Al}$ concentration.

\subsection{Chromium Dissolution}

Figures 3.7, 3.8, and 3.9 illustrate the $\mathrm{Cr}$ dissolution at 60,80 , and $100{ }^{\circ} \mathrm{C}$, respectively. Unlike the $\mathrm{Al}$ behavior, increased hydroxide concentration led to higher $\mathrm{Cr}$ concentrations at $60^{\circ} \mathrm{C}$. But similar to the $\mathrm{Al}$ behavior, the $\mathrm{Cr}$ concentration did not appear to reach a steady value after $168 \mathrm{~h}$ of leaching at 60 ${ }^{\circ} \mathrm{C}$. At $80^{\circ} \mathrm{C}$, Cr dissolution was similar in 3 and $5 \mathrm{M} \mathrm{NaOH}$; $\mathrm{Cr}$ dissolution in $1 \mathrm{M} \mathrm{NaOH}$ was slower but reached essentially the same final concentration (approximately $225 \mu \mathrm{g} / \mathrm{g}$ ) after leaching for $168 \mathrm{~h}$. The Cr behavior at $100^{\circ} \mathrm{C}$ was similar to that at $80^{\circ} \mathrm{C}$ except that dissolution was somewhat more rapid.

Figures 3.10, 3.11, and 3.12 illustrate the $\mathrm{Cr}$ dissolution at 1, 3, and $5 \mathrm{M} \mathrm{NaOH}$, respectively. The data are presented in terms of both the $\mathrm{Cr}$ concentration and the percentage of $\mathrm{Cr}$ removed as a function of time. These figures clearly illustrate more rapid $\mathrm{Cr}$ dissolution with increasing temperature, but the data also suggest that the same level of $\mathrm{Cr}$ removal would probably be reached for all hydroxide concentrations and temperature if sufficient time were allowed.

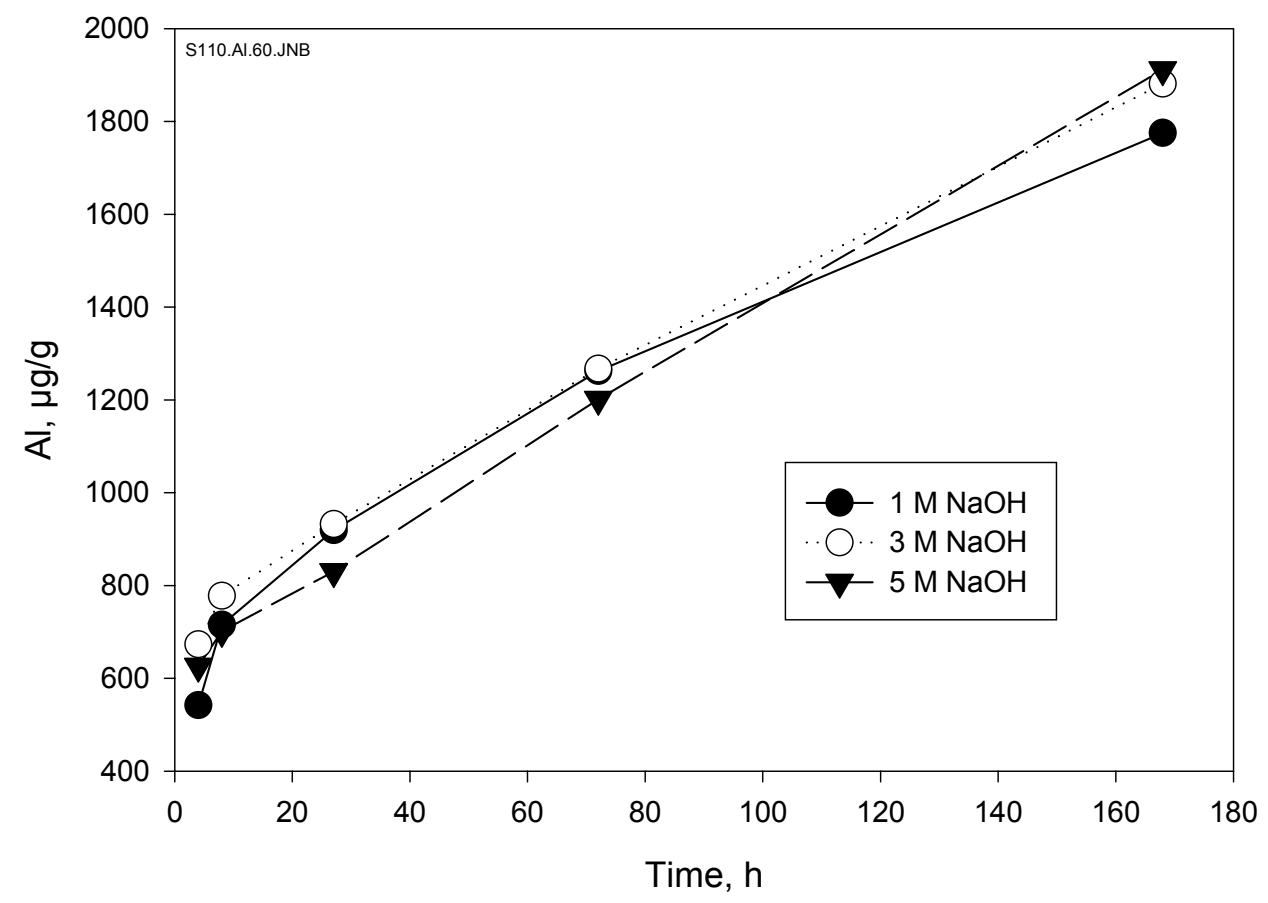

Figure 3.1. Aluminum Concentration as a Function of Time During Leaching of S- 110 Solids at $60^{\circ} \mathrm{C}$

(a) AR Felmy, Pacific Northwest National Laboratory, personal communication, 2001. 


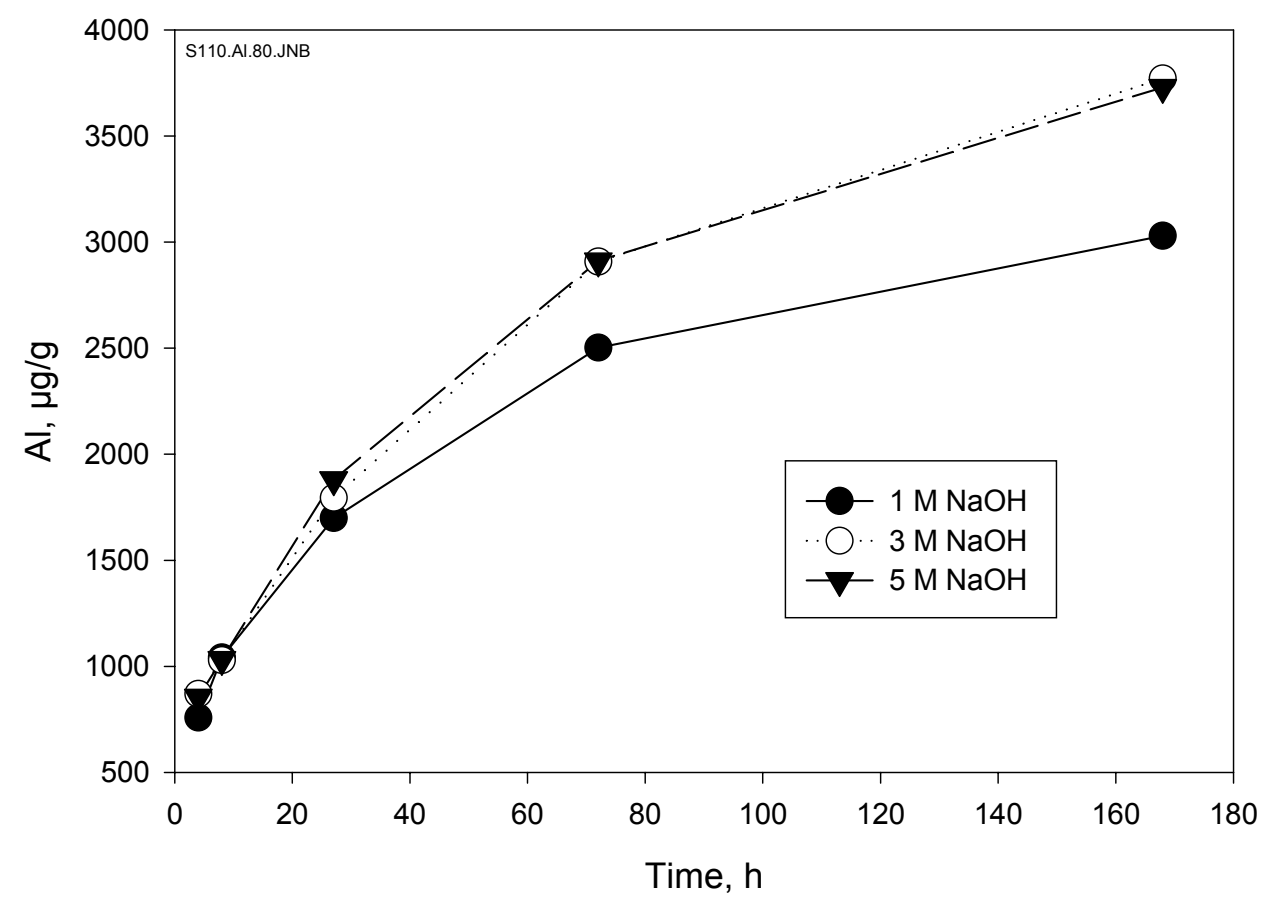

Figure 3.2. Aluminum Concentration as a Function of Time During Leaching of S-110 Solids at $80^{\circ} \mathrm{C}$

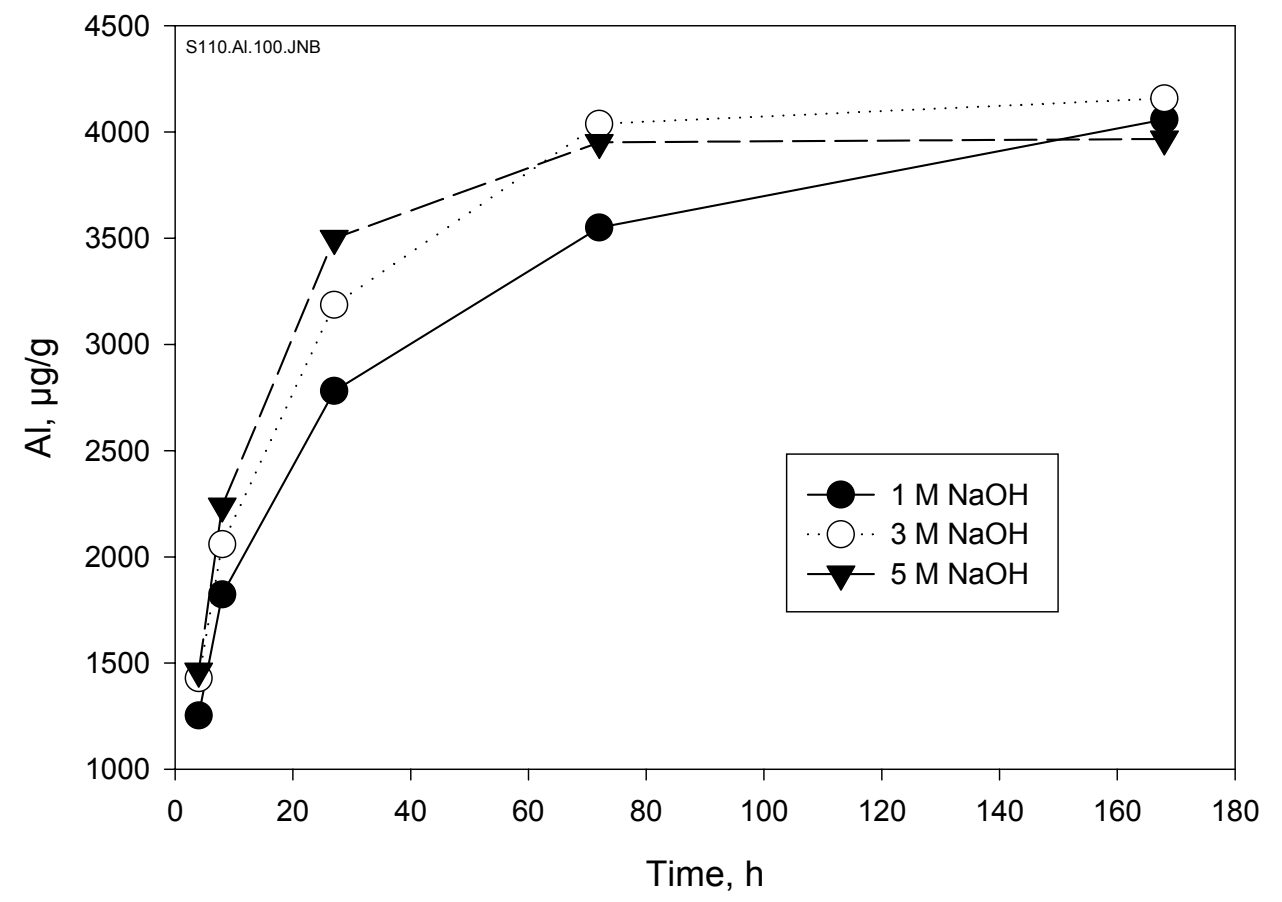

Figure 3.3. Aluminum Concentration as a Function of Time During Leaching of S-110 Solids at $100^{\circ} \mathrm{C}$ 


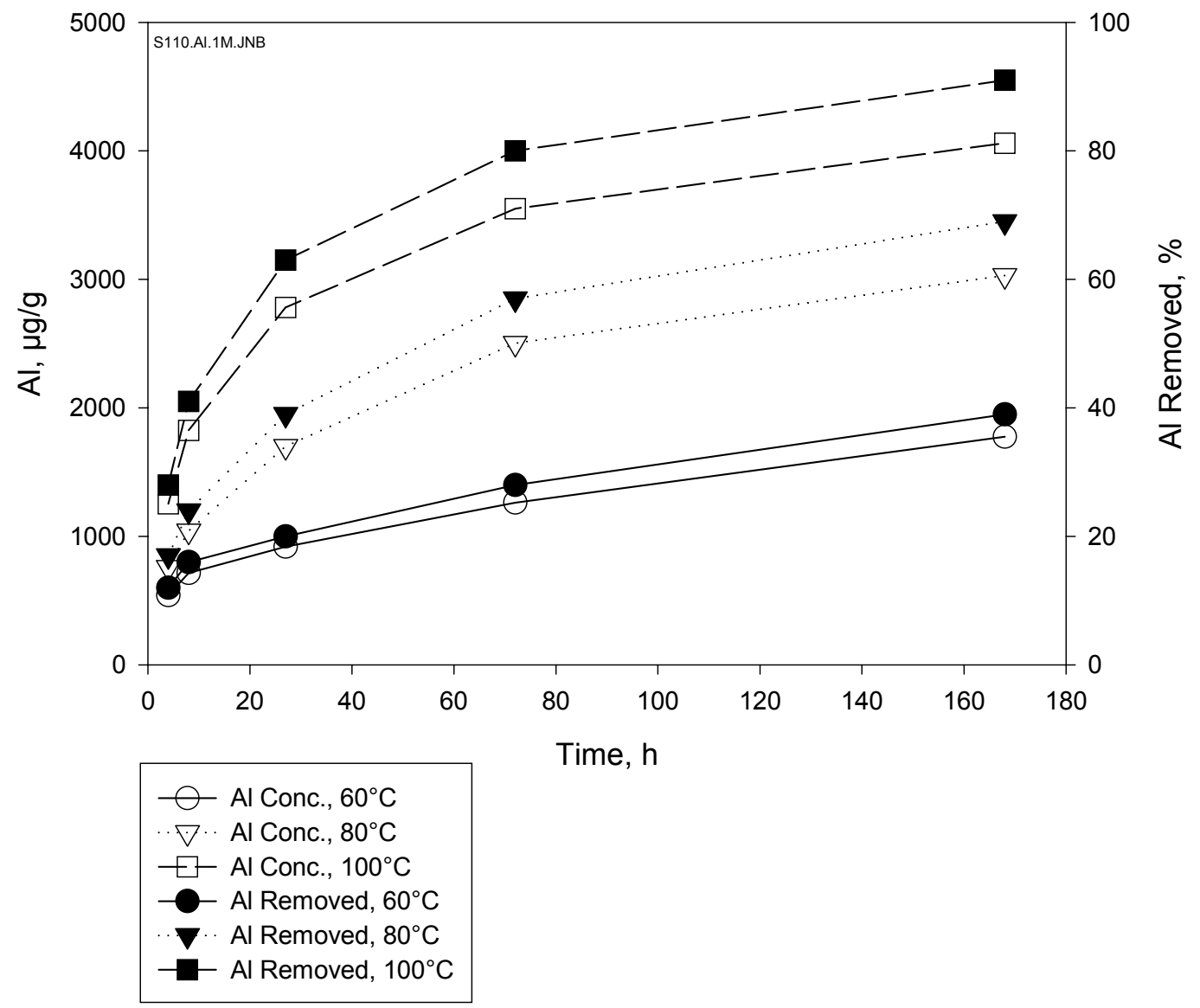

Figure 3.4. Aluminum Concentration and Removal as a Function of Time During Leaching of S-110 Solids at $1 \mathrm{M} \mathrm{NaOH}$ 


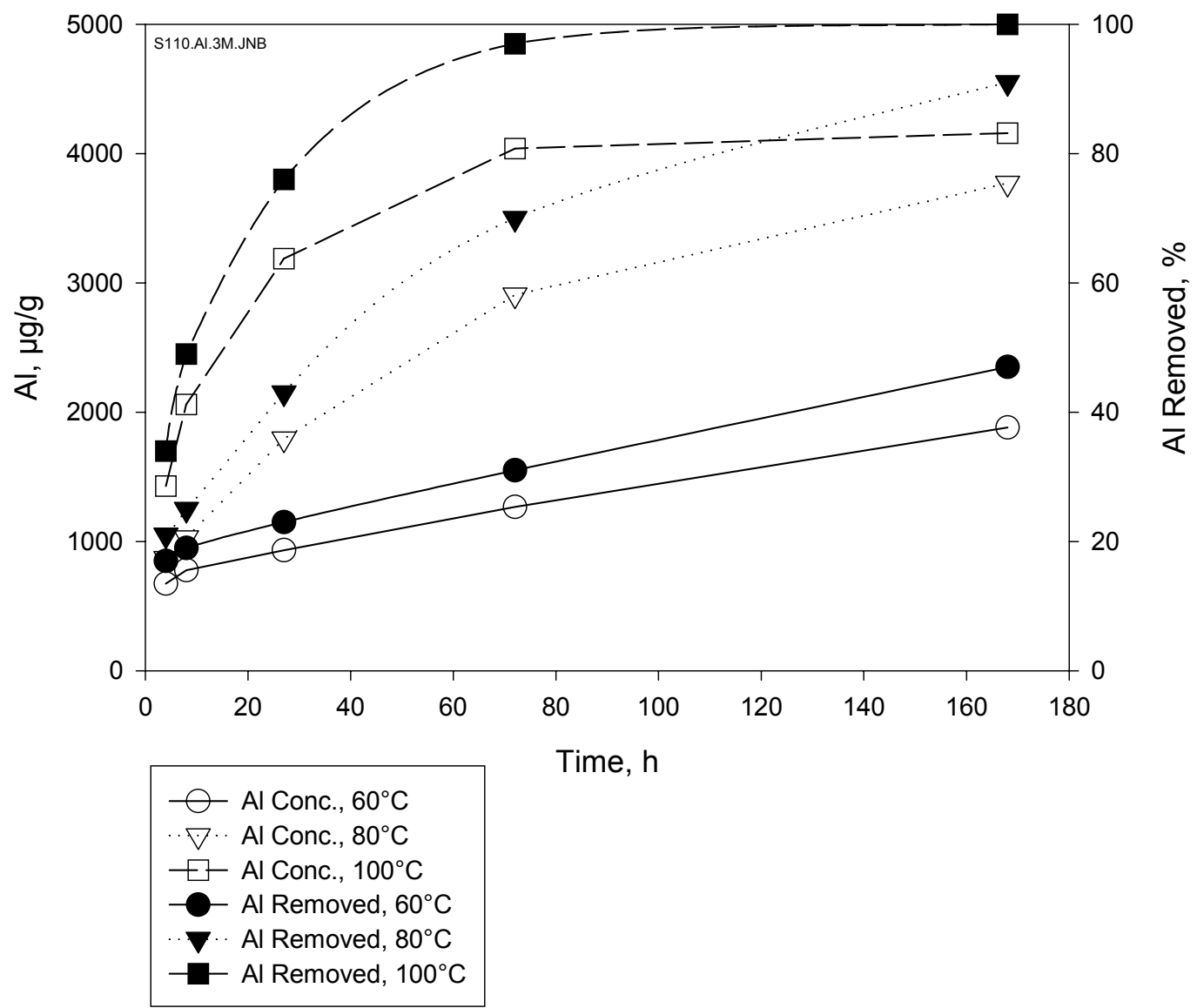

Figure 3.5. Aluminum Concentration and Removal as a Function of Time During Leaching of S-110 Solids at $3 \mathrm{M} \mathrm{NaOH}$ 


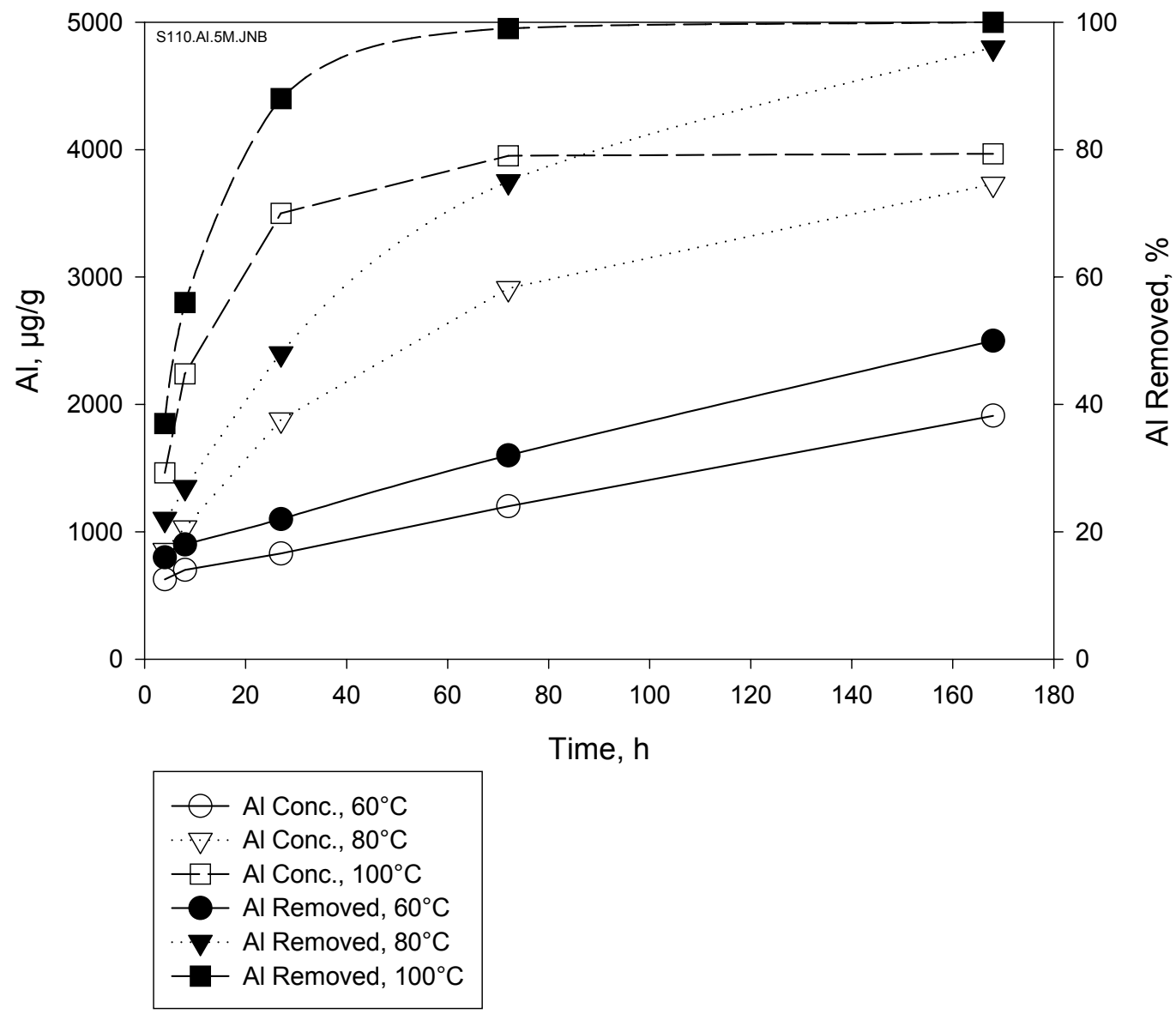

Figure 3.6. Aluminum Concentration and Removal as a Function of Time During Leaching of S-110 Solids at $5 \mathrm{M} \mathrm{NaOH}$ 


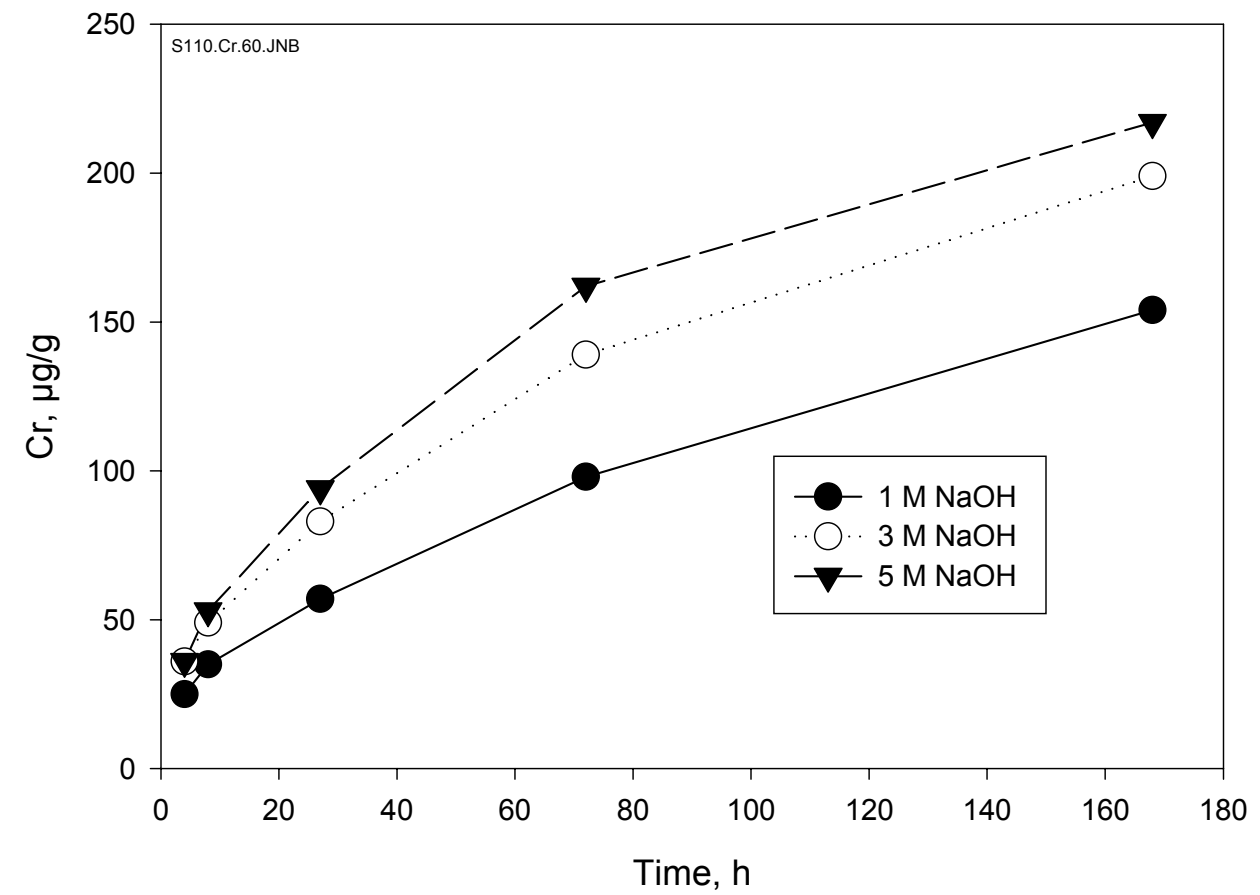

Figure 3.7. Chromium Concentration as a Function of Time During Leaching of S- 110 Solids at $60^{\circ} \mathrm{C}$

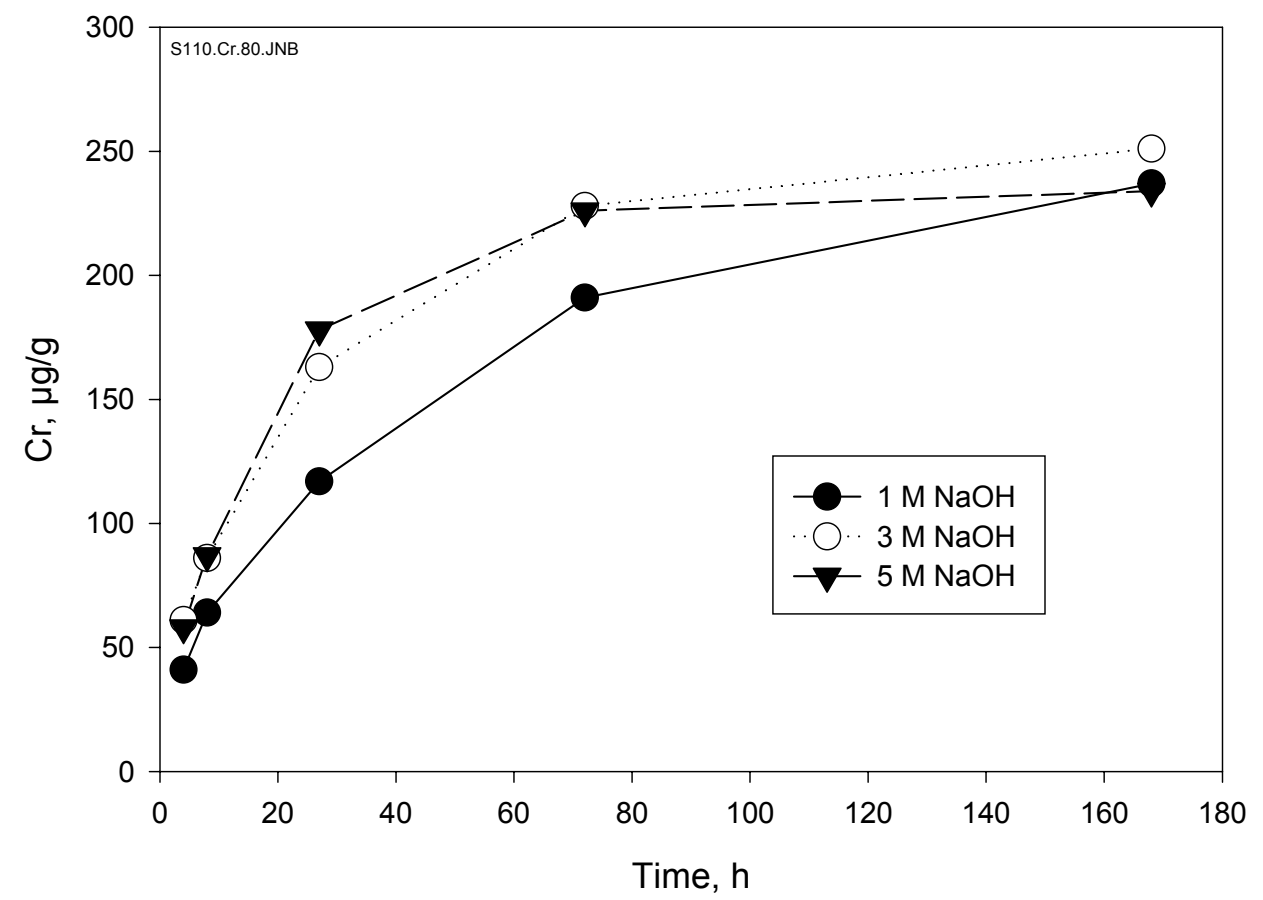

Figure 3.8. Chromium Concentration as a Function of Time During Leaching of S-1 10 Solids at $80^{\circ} \mathrm{C}$ 


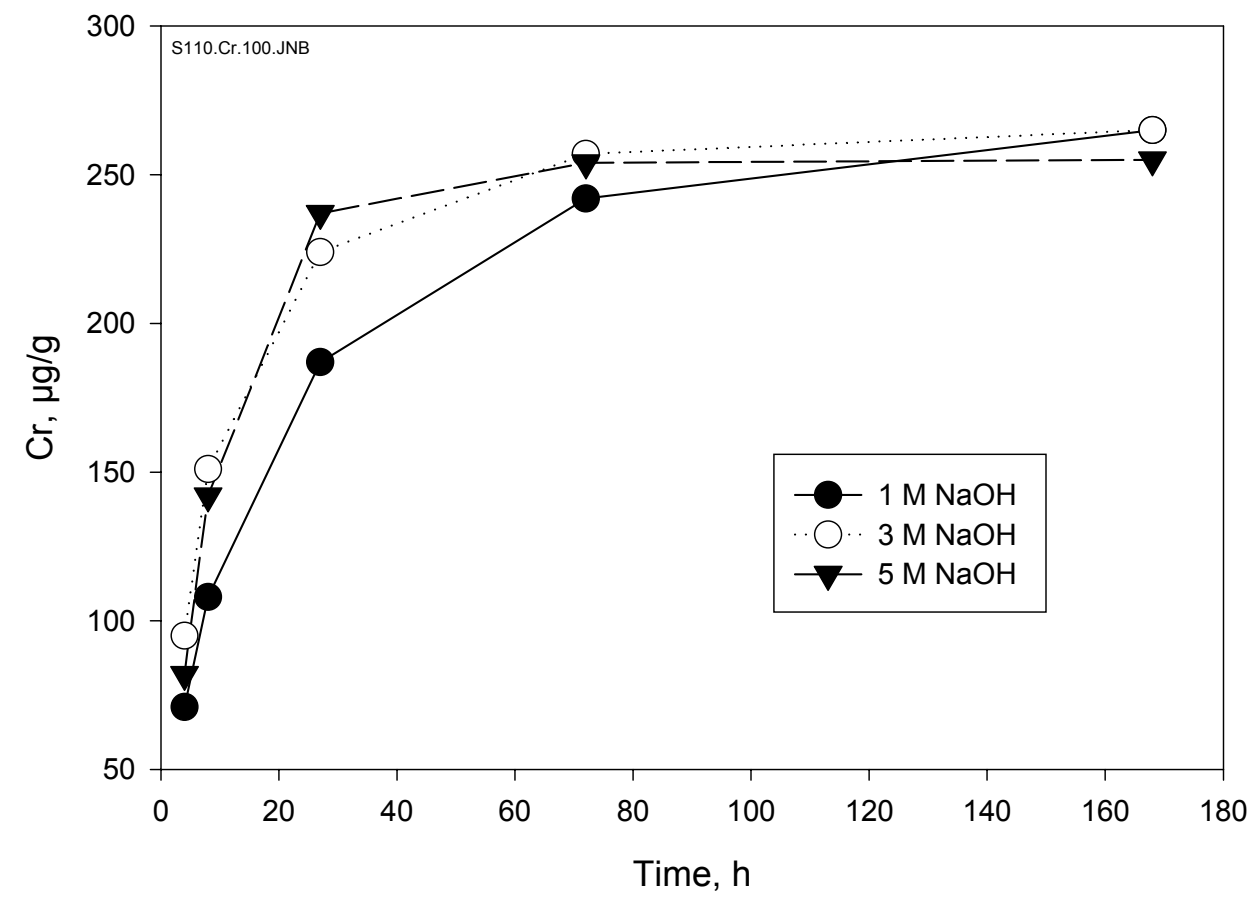

Figure 3.9. Chromium Concentration as a Function of Time During Leaching of S- 110 Solids at $100^{\circ} \mathrm{C}$ 


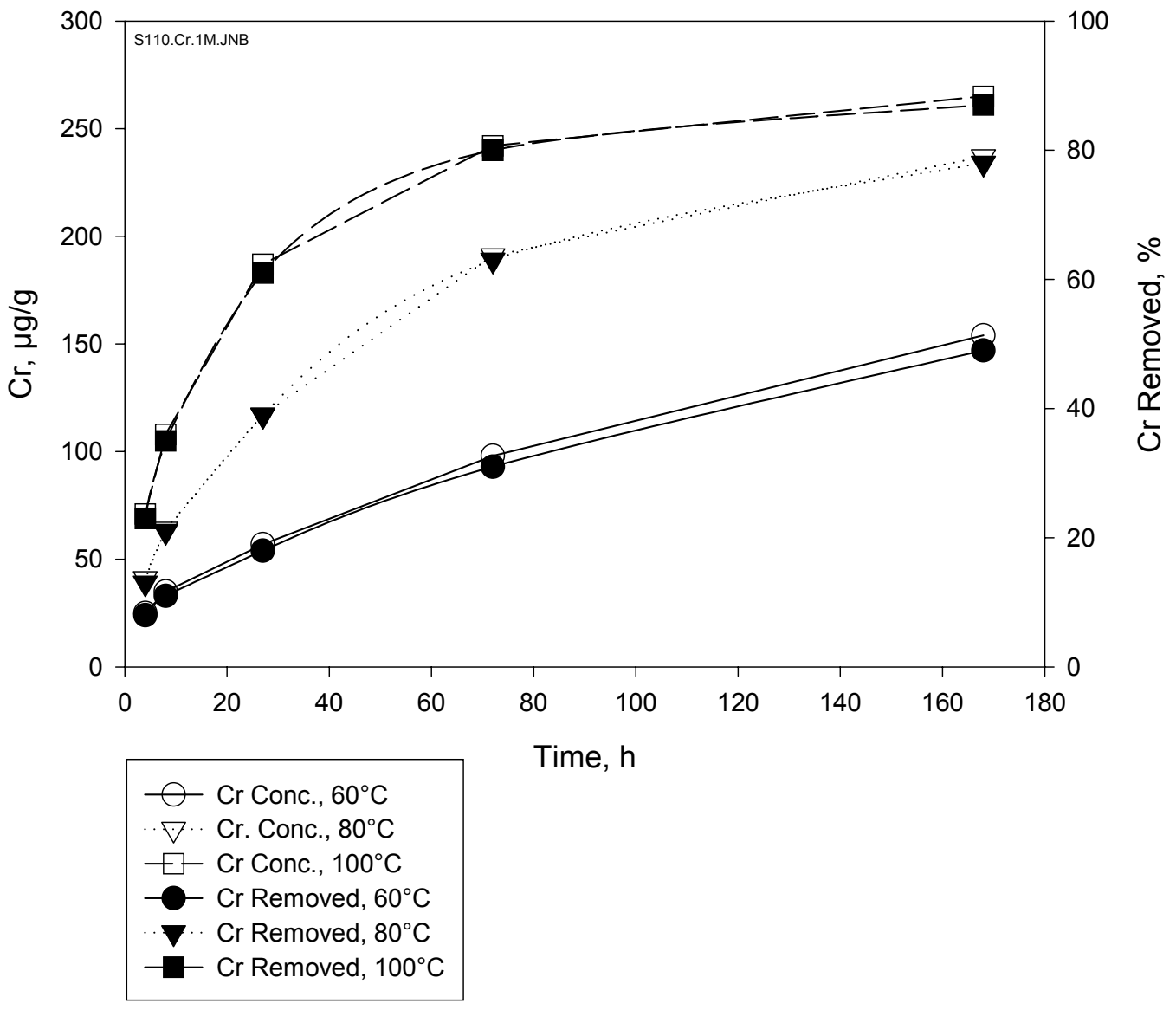

Figure 3.10. Chromium Concentration and Removal as a Function of Time During Leaching of S-110 Solids at $1 \mathrm{M} \mathrm{NaOH}$ 


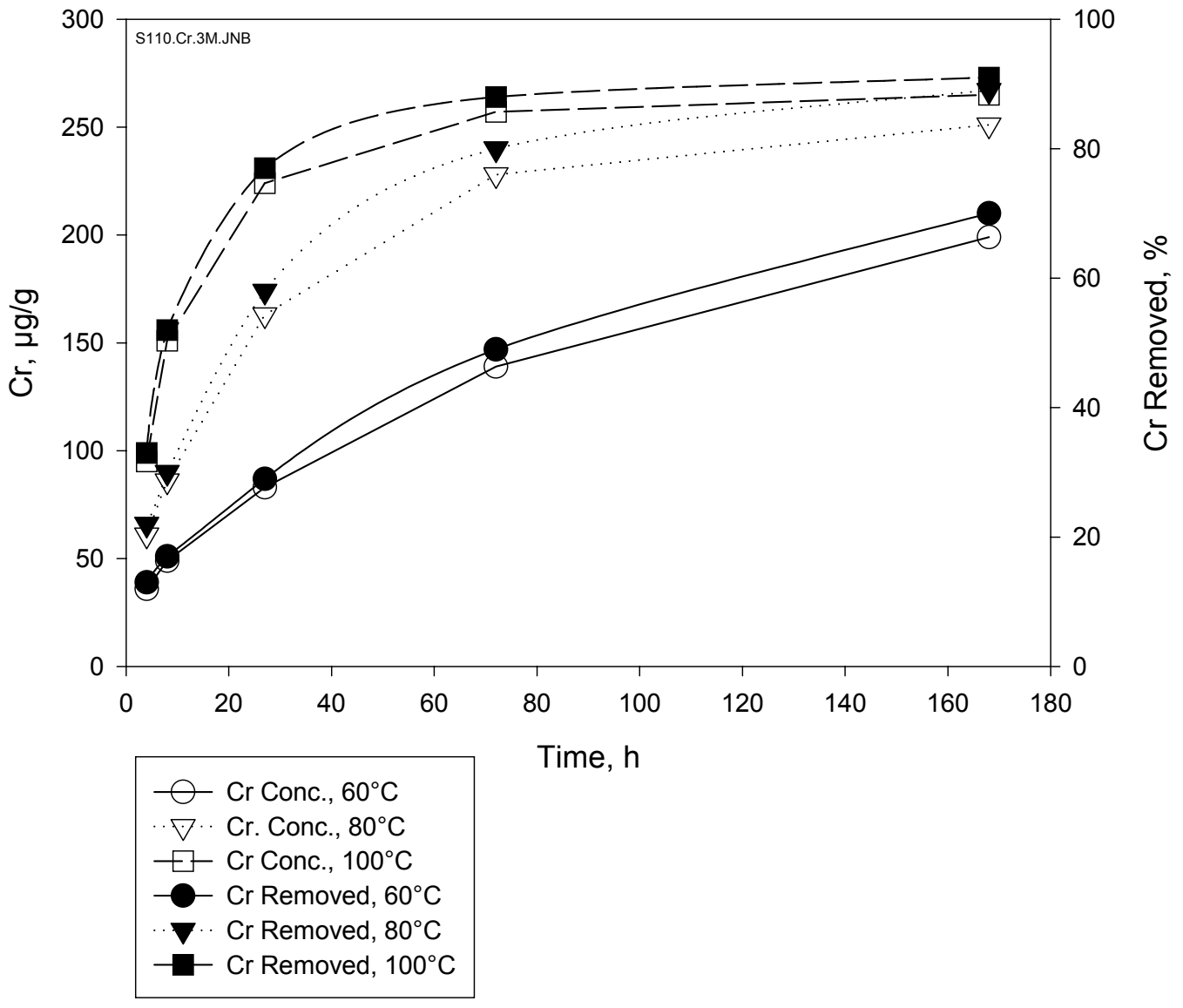

Figure 3.11. Chromium Concentration and Removal as a Function of Time During Leaching of S-110 Solids at $3 \mathrm{M} \mathrm{NaOH}$ 


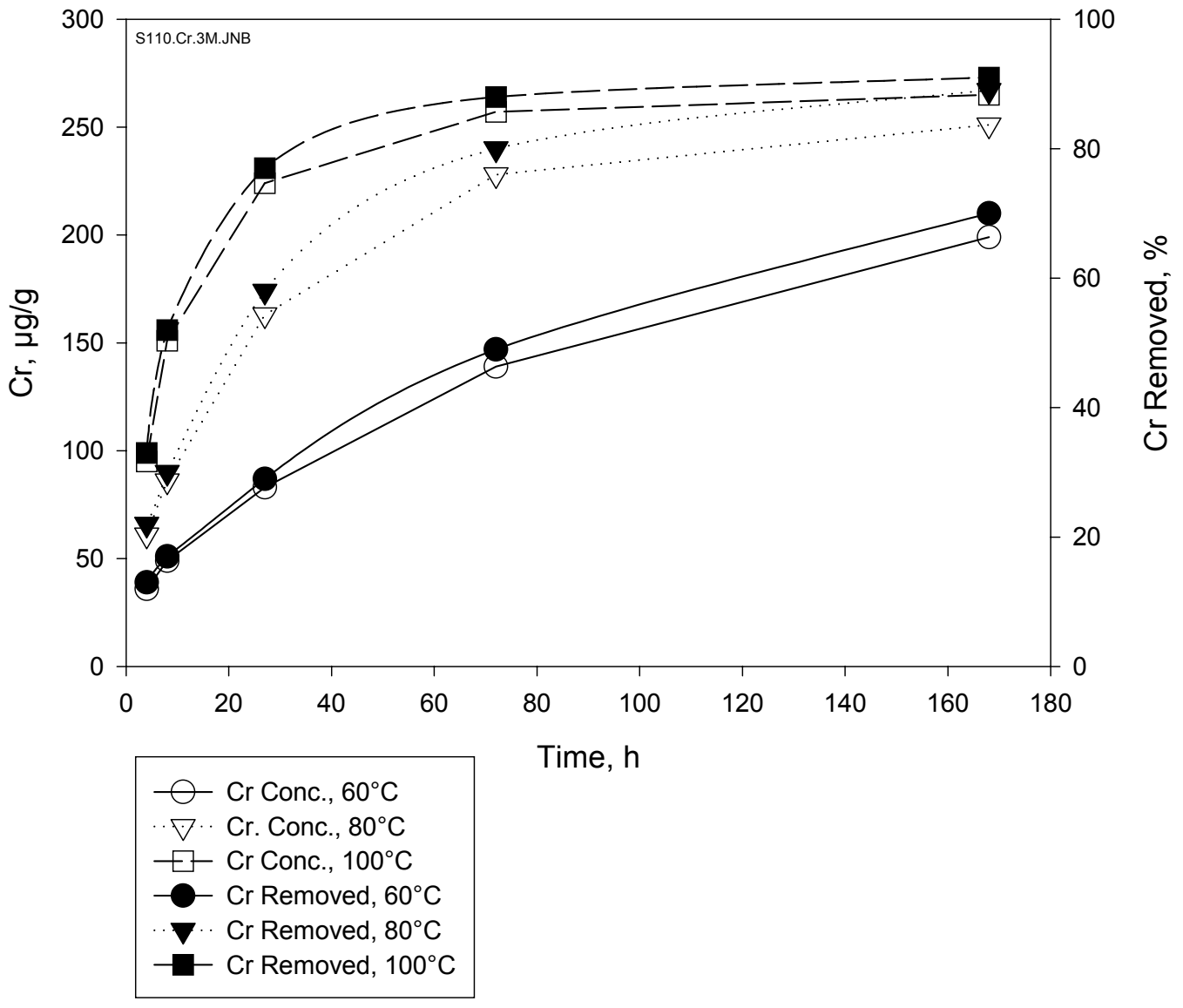

Figure 3.12. Chromium Concentration and Removal as a Function of Time During Leaching of S-110 Solids at $5 \mathrm{M} \mathrm{NaOH}$

\subsection{Radionuclide Behavior}

Appendix C summarizes the behavior of the radionuclides in the S-110 caustic leaching tests. Under all conditions examined, greater than $90 \%$ of the ${ }^{137} \mathrm{Cs}$ reported to the leaching solution. There was no significant effect of temperature upon the ${ }^{137} \mathrm{Cs}$ behavior, but increasing $\mathrm{NaOH}$ concentration led to increased ${ }^{137} \mathrm{Cs}$ removal from the S-110 solids. As expected, the lanthanide and actinide isotopes were largely insoluble in the highly alkaline leaching solutions.

The highest transuranic (TRU) concentration in the leachate was $\sim 3.5 \times 10^{-4} \mu \mathrm{Ci} / \mathrm{g}$ (e.g., for leaching with $5 \mathrm{M} \mathrm{NaOH}$ at 60 or $100^{\circ} \mathrm{C}$ ). To assess whether this would lead to an immobilized low-activity waste (ILAW) form exceeding the $10 \mathrm{nCi}$ TRU/g limit for Class A LLW (10 CFR 61. 1988. U.S. Nuclear Regulatory Commission, "Licensing Requirements for Land Disposal of Radioactive Waste." U.S. Code of Federal Regulations), we considered a $1 \mathrm{M} \mathrm{NaOH}$ leaching solution with a TRU concentration of $3.5 \mathrm{x}$ $10^{-4} \mu \mathrm{Ci} / \mathrm{g}$ as a limiting case. Assuming that the ILAW form contains $20 \mathrm{wt} \% \mathrm{Na}_{2} \mathrm{O}$, the resulting TRU concentration would be $2.4 \mathrm{nCi} / \mathrm{g}$. Thus, it appears the leaching solutions would not exceed the TRU criteria for LAW. 
A similar analysis can be done for ${ }^{137} \mathrm{Cs}$. In this case, the highest concentration was approximately $0.43 \mu \mathrm{Ci} / \mathrm{g}$. Assuming that the ILAW form contains $20 \mathrm{wt} \% \mathrm{Na}_{2} \mathrm{O}$ and has a density of $2.7 \mathrm{MT} / \mathrm{m}^{3}$, immobilization of a $1 \mathrm{M} \mathrm{NaOH}$ leachate containing $0.43 \mu \mathrm{Ci} / \mathrm{g}{ }^{137} \mathrm{Cs}$ would lead to a waste form with 8 $\mathrm{Ci} / \mathrm{m}^{3}$. This exceeds the U.S. Nuclear Regulatory Commission (NRC) Class A limit of $1 \mathrm{Ci}^{137} \mathrm{Cs} / \mathrm{m}^{3}$ (but is well within the Class B limit of $44 \mathrm{Ci}^{137} \mathrm{Cs} / \mathrm{m}^{3}$ ). Thus, if the ILAW waste form is to meet Class A criteria, the ${ }^{137} \mathrm{Cs}$ must be removed from the leaching solutions.

\subsection{Impact of Leaching on Immobilized High-Level Waste Glass Mass}

To illustrate the effects of caustic leaching on the production of IHLW glass, Table 3.3 shows the concentration of waste oxides in the dilute hydroxide-washed S-110 solids and in the leached S-110 solids. For the sake of discussion, the table also shows the concentrations of waste-derived components that would result from vitrifying these solids at $25 \mathrm{wt} \%$ waste oxide loading (WOL), excluding oxides of $\mathrm{Na}$ and Si. Two cases are presented-leaching with $3 \mathrm{M} \mathrm{NaOH}$ at $80^{\circ} \mathrm{C}$ and at $100^{\circ} \mathrm{C}$ for 1 week. The oxide concentrations in the washed and leached solids were determined by converting the elemental concentrations listed in Tables 2.2 (washed solids), B.5, and B.8 (leached solids) to the corresponding oxide concentrations. The oxide concentrations in the IHLW were determined according to the following formula:

$$
\left[\mathrm{C}_{\mathrm{x}}\right]_{\mathrm{IHLW}}=\mathrm{WOL} \bullet\left(\frac{\mathrm{C}_{\mathrm{x}}}{\sum_{\mathrm{i}} \mathrm{C}_{\mathrm{i}}}\right)
$$

where $\left[\mathrm{C}_{\mathrm{x}}\right]_{\mathrm{IHLW}}$ is the concentration of component $\mathrm{x}$ oxide $(\mathrm{wt} \%)$ in the IHLW, $\mathrm{C}_{\mathrm{x}}$ is the concentration of component $x$ oxide in the washed or leached solids, and $\sum \mathrm{C}_{\mathrm{i}}$ is the sum of the concentration of all the component oxides in the washed or leached solids (excluding $\mathrm{Na}_{2} \mathrm{O}$ and $\mathrm{SiO}_{2}$ ).

Assuming upper limits of 15, 0.5, and $3.0 \mathrm{wt} \%$ for $\mathrm{Al}, \mathrm{Cr}$, and $\mathrm{P}$ oxides, respectively, in the IHLW, a $25 \mathrm{wt} \%$ WOL could not be achieved for the dilute-hydroxide washed S-110 solids. Both $\mathrm{Al}$ and $\mathrm{Cr}$ exceed the assumed upper limits. Leaching with $3 \mathrm{M} \mathrm{NaOH}$ for 1 week at 80 or $100^{\circ} \mathrm{C}$ would remove enough $\mathrm{Al}$ so that $\mathrm{Al}$ is not a limiting component. However, even after leaching for 1 week at $100^{\circ} \mathrm{C}$, $\mathrm{Cr}_{2} \mathrm{O}_{3}$ would still exceed the assumed $0.5 \mathrm{wt} \%$ limit.

The mass $\left(\mathrm{W}_{\text {IHLW }}\right)$ of IHLW glass produced from $1 \mathrm{~g}$ of the washed solids can be calculated as follows:

$$
\mathrm{W}_{\text {IHLW }}=100 \bullet \frac{\sum_{\mathrm{i}} \mathrm{C}_{\mathrm{i}}}{\mathrm{WOL}}
$$

Likewise, the mass of IHLW glass produced from the leached solids derived from $1 \mathrm{~g}$ of washed solids can be determined as follows: 


$$
\mathrm{W}_{\mathrm{IHLW}}=100 \bullet \frac{\mathrm{W}_{\mathrm{L}}}{\mathrm{W}_{\mathrm{W}}} \cdot \frac{\sum_{\mathrm{i}} \mathrm{C}_{\mathrm{i}}}{\mathrm{WOL}}
$$

where $\mathrm{W}_{\mathrm{L}}$ is the weight of the leached solids obtained by leaching $\mathrm{W}_{\mathrm{W}}$ grams of washed solids. In the case considered here, $\mathrm{W}_{\mathrm{L}}=0.207 \mathrm{~g}$ and $\mathrm{W}_{\mathrm{W}}=1.158 \mathrm{~g}$ for the $3 \mathrm{M} / 80^{\circ} \mathrm{C}$ test and $\mathrm{W}_{\mathrm{L}}=0.107 \mathrm{~g}$ and $\mathrm{W}_{\mathrm{W}}=1.173 \mathrm{~g}$ for the $3 \mathrm{M} / 100^{\circ} \mathrm{C}$ test. Setting the upper limit for $\mathrm{Cr}_{2} \mathrm{O}_{3}$ in the IHLW as $0.5 \mathrm{wt} \%$, it can be derived from Equation 3.1 that the maximum WOL achievable for the washed S-110 solids would be $10.6 \mathrm{wt} \%$. At this WOL, application of Equation 3.2 indicates that $6.74 \mathrm{~g} \mathrm{IHLW}$ would be produced per gram of washed S-110 solids. Likewise, setting the upper limit for $\mathrm{Cr}_{2} \mathrm{O}_{3}$ in the IHLW as $0.5 \mathrm{wt} \%$, the maximum WOL that could be achieved for the leached $\left(3 \mathrm{M} \mathrm{NaOH}\right.$ at $\left.80^{\circ} \mathrm{C}\right) \mathrm{S}-110$ solids would be $15.1 \mathrm{wt} \%$. At this WOL, application of Equation 3.3 indicates that $0.84 \mathrm{~g}$ IHLW would be produced per gram of washed S-101 solids. Thus, a reduction in IHLW of $88 \%$ could be achieved by leaching the $\mathrm{S}-101$ solids with $3 \mathrm{M} \mathrm{NaOH}$ for 1 week at $80^{\circ} \mathrm{C}$. Interestingly, applying an upper limit of $0.5 \mathrm{wt} \% \mathrm{Cr}_{2} \mathrm{O}_{3}$ in the IHLW would result in a maximum WOL of only $9.2 \%$ for the residue remaining after leaching the S-1 10 solids with $3 \mathrm{M} \mathrm{NaOH}$ at $100^{\circ} \mathrm{C}$ for 1 week. Because of this, only a marginal improvement $(90 \%$ reduction in IHLW) would be achieved by leaching at $100^{\circ} \mathrm{C}$ versus $80^{\circ} \mathrm{C}$.

\subsection{Conclusions and Recommendations}

The work presented here indicates caustic leaching to be a very effective method of pretreating Hanford Tank S-110 sludge. Because of the predominance of boehmite in the water-insoluble S-110 solids, high caustic and temperature are required to sufficiently remove Al. It would also be necessary to leach for several days to realize the full benefits of caustic leaching. Leaching at $60^{\circ} \mathrm{C}$ only removed $\sim 50 \%$ of the $\mathrm{Al}$ even after leaching with $5 \mathrm{M} \mathrm{NaOH}$ for 1 week. Increasing the temperature led to significant improvements in $\mathrm{Al}$ removal. The best $\mathrm{Al}$ removal was obtained by leaching with $5 \mathrm{M} \mathrm{NaOH}$ at $100^{\circ} \mathrm{C}$ for 1 week; this led to nearly quantitative removal of $\mathrm{Al}$ from the $\mathrm{S}-110$ solids. However, the benefit in using $5 \mathrm{M} \mathrm{NaOH}$ instead of $3 \mathrm{M} \mathrm{NaOH}$ is marginal. The $\mathrm{Cr}$ behavior parallels that of $\mathrm{Al}$, with increasing removal obtained with increasing $[\mathrm{NaOH}]$, temperature, or leaching time.

At a maximum of $0.5 \mathrm{wt} \% \mathrm{Cr}_{2} \mathrm{O}_{3}$ in the HLW form, the mass of IHLW would be constrained by the Cr content of the leached S-110 solids. Nevertheless, an 80 to $90 \%$ reduction in IHLW mass from the S-110 solids should be readily achievable.

The results of this work underscore the need to continue process optimization studies. If subjected to the baseline leaching approach $\left(3 \mathrm{M} \mathrm{NaOH}, 80\right.$ to $90^{\circ} \mathrm{C}$, for $8 \mathrm{~h}$ ), only about $25 \%$ of the $\mathrm{Al}$ would be leached from the dilute hydroxide-washed S-110 solids. Clearly, this would not be sufficient to adequately reduce the IHLW mass. 
Table 3.3. Estimated Concentrations of Waste-Derived Components in the IHLW Glass from S-110 Waste

\begin{tabular}{|c|c|c|}
\hline \multirow[b]{2}{*}{ Component } & \multicolumn{2}{|c|}{ Washed Solids } \\
\hline & g oxide/g solids & Conc. in IHLW, $\mathrm{wt}^{(\mathrm{a})}$ \\
\hline $\mathrm{Al}_{2} \mathrm{O}_{3}$ & 0.6143 & 21.5 \\
\hline $\mathrm{BaO}$ & 0.0001 & 0.00 \\
\hline $\mathrm{Bi}_{2} \mathrm{O}_{3}$ & 0.0015 & 0.05 \\
\hline $\mathrm{CaO}$ & 0.0017 & 0.1 \\
\hline $\mathrm{Cr}_{2} \mathrm{O}_{3}$ & 0.0337 & 1.2 \\
\hline $\mathrm{Fe}_{2} \mathrm{O}_{3}$ & 0.0202 & 0.7 \\
\hline $\mathrm{MgO}$ & 0.0006 & 0.0 \\
\hline $\mathrm{MnO}_{2}$ & 0.0084 & 0.3 \\
\hline $\mathrm{P}_{2} \mathrm{O}_{5}$ & 0.0032 & 0.1 \\
\hline $\mathrm{SrO}$ & 0.0015 & 0.05 \\
\hline $\mathrm{UO}_{3}$ & 0.0282 & 1.0 \\
\hline $\mathrm{ZnO}$ & 0.0003 & 0.01 \\
\hline \multirow{2}{*}{$\mathrm{ZrO}_{2}$} & 0.0002 & 0.01 \\
\hline & \multicolumn{2}{|c|}{ Leached Solids (3 M NaOH/80 $\left.{ }^{\circ} \mathrm{C} / 168 \mathrm{~h}\right)$} \\
\hline Component & g oxide/g solids & Conc. in IHLW, wt\% (a) $^{(\mathbf{a})}$ \\
\hline $\mathrm{Al}_{2} \mathrm{O}_{3}$ & 0.3644 & 12.8 \\
\hline $\mathrm{BaO}$ & 0.0009 & 0.03 \\
\hline $\mathrm{Bi}_{2} \mathrm{O}_{3}$ & 0.0051 & 0.18 \\
\hline $\mathrm{CaO}$ & 0.0085 & 0.3 \\
\hline $\mathrm{Cr}_{2} \mathrm{O}_{3}$ & 0.0236 & 0.8 \\
\hline $\mathrm{Fe}_{2} \mathrm{O}_{3}$ & 0.1089 & 3.8 \\
\hline $\mathrm{MgO}$ & 0.0032 & 0.1 \\
\hline $\mathrm{MnO}_{2}$ & 0.0476 & 1.7 \\
\hline $\mathrm{P}_{2} \mathrm{O}_{5}$ & 0.0007 & 0.0 \\
\hline $\mathrm{SrO}$ & 0.0088 & 0.31 \\
\hline $\mathrm{UO}_{3}$ & 0.1380 & 4.8 \\
\hline $\mathrm{ZnO}$ & 0.0007 & 0.02 \\
\hline \multirow[t]{2}{*}{$\mathrm{ZrO}_{2}$} & 0.0013 & 0.04 \\
\hline & \multicolumn{2}{|c|}{ Leached Solids $\left(3 \mathrm{M} \mathrm{NaOH} / 100^{\circ} \mathrm{C} / 168 \mathrm{~h}\right)$} \\
\hline Component & g oxide/g solids & Conc. in IHLW, wt\% (a) $^{(\mathrm{a})}$ \\
\hline $\mathrm{Al}_{2} \mathrm{O}_{3}$ & 0.0248 & 0.9 \\
\hline $\mathrm{BaO}$ & 0.0018 & 0.07 \\
\hline $\mathrm{Bi}_{2} \mathrm{O}_{3}$ & 0.0092 & 0.34 \\
\hline $\mathrm{CaO}$ & 0.0167 & 0.6 \\
\hline $\mathrm{Cr}_{2} \mathrm{O}_{3}$ & 0.0363 & 1.4 \\
\hline $\mathrm{Fe}_{2} \mathrm{O}_{3}$ & 0.2000 & 7.5 \\
\hline $\mathrm{MgO}$ & 0.0062 & 0.2 \\
\hline $\mathrm{MnO}_{2}$ & 0.0909 & 3.4 \\
\hline $\mathrm{P}_{2} \mathrm{O}_{5}$ & 0.0018 & 0.1 \\
\hline $\mathrm{SrO}$ & 0.0172 & 0.64 \\
\hline $\mathrm{UO}_{3}$ & 0.2618 & 9.8 \\
\hline $\mathrm{ZnO}$ & 0.0009 & 0.03 \\
\hline $\mathrm{ZrO}_{2}$ & 0.0023 & 0.09 \\
\hline
\end{tabular}




\subsection{References}

10 CFR 61. 1988. U.S. Nuclear Regulatory Commission, "Licensing Requirements for Land Disposal of Radioactive Waste." U.S. Code of Federal Regulations.

Hill, J. G., G. S. Anderson, and B. C. Simpson. 1995. The Sort on Radioactive Waste Type Model: A Method to Sort Single-Shell Tanks into Characteristic Groups, PNL-9814 Rev. 2, Pacific Northwest National Laboratory, Richland, Washington.

Lumetta, G. J. and B. M. Rapko. 1994. Washing and Alkaline Leaching of Hanford Tank Sludges: A Status Report, PNL-10078, Pacific Northwest National Laboratory, Richland, Washington.

Lumetta, G. J., B. M. Rapko, M. J. Wagner, J. Liu, and Y. L. Chen. 1996a. Washing and Caustic Leaching of Hanford Tank Sludges: Results of FY 1996 Studies, PNNL-11278, Rev. 1, Pacific Northwest National Laboratory, Richland, Washington.

Lumetta, G. J., M. J. Wagner, F. V. Hoopes, R. T. Steele. 1996b. Washing and Caustic Leaching of Hanford Tank C-106 Sludge, PNNL-11381, Pacific Northwest National Laboratory, Richland, Washington.

Lumetta, G. J., I. E. Burgeson, M. J. Wagner, J. Liu, and Y. L. Chen. 1997. Washing and Caustic Leaching of Hanford Tank Sludges: Results of FY 1997 Studies, PNNL-11636, Pacific Northwest National Laboratory, Richland, Washington.

Lumetta, G. J., B. M. Rapko, J. Liu, D. J. Temer, and R. D. Hunt. 1998. Washing and Caustic Leaching of Hanford Tank Sludges: Results of FY 1998 Studies, PNNL-12026, Pacific Northwest National Laboratory, Richland, Washington.

Rai, D., M. Sass, and D. A. Moore. 1987. "Chromium(III) Hydrolysis Constants and Solubility of Chromium(III) Hydroxide.” Inorg. Chem., 26: 345-349.

Rapko, B. M, G. J. Lumetta, and M. J. Wagner. 1995. Washing and Caustic Leaching of Hanford Tank Sludges: Results of FY 1995 Studies, PNL-10712, Pacific Northwest Laboratory, Richland, Washington.

Temer, D. J. and R. Villarreal. 1995. Sludge Washing and Alkaline Leaching Tests on Actual Hanford Tank Sludge: A Status Report, LAUR-95-2070, Los Alamos National Laboratory, Los Alamos, New Mexico.

Temer, D. J. and R. Villarreal. 1996. Sludge Washing and Alkaline Leaching Tests on Actual Hanford Tank Sludge: FY 1996 Results, LAUR-96-2839, Los Alamos National Laboratory, Los Alamos, New Mexico.

Temer, D. J., and R. Villerreal. 1997. Sludge Washing and Alkaline Leaching Tests on Actual Hanford Tank Sludge: FY 1997 Results, LAUR-97-2889, Los Alamos National Laboratory, Los Alamos, New Mexico.

U.S. Department of Energy/Office or River Protection (DOE/ORP). 2001. River Protection Project - 
Project Management Plan, DOE/ORP-2000-06, Richland, Washington.

http://www.hanford.gov/orp/documents/orp-2000-06/index.html\#P572_20332

Weber, E. J. 1982. Aluminum Hydroxide Dissolution in Synthetic Sludges, DP-1617, Savannah River Laboratory, Aiken, South Carolina. 


\section{Appendix A}

Solution Concentrations as a Function of Time 



\section{Appendix A: Solution Concentrations as a Function of Time}

Table A.1. Component Concentrations As a Function of Time For Leaching of S-110 Solids With $1 \mathrm{M} \mathrm{NaOH}$ at $60^{\circ} \mathrm{C}$

\begin{tabular}{|c|c|c|c|c|c|c|c|}
\hline \multirow{3}{*}{$\begin{array}{l}\text { Time, h: } \\
\text { Ag }\end{array}$} & \multicolumn{7}{|c|}{ Concentration, $\mu \mathrm{g} / \mathrm{g}^{(\mathrm{a})}$} \\
\hline & 4 & 8 & 24 & 72 & 168 & 168 & Final Wash \\
\hline & & & & & & & \\
\hline $\mathrm{Al}$ & 542 & 715 & 919 & 1262 & 1811 & 1739 & 178 \\
\hline As & & & & & & & \\
\hline B & & & & & & & \\
\hline $\mathrm{Ba}$ & & & & & & & \\
\hline $\mathrm{Be}$ & & & & & & & \\
\hline $\mathrm{Bi}$ & & & & & & & \\
\hline $\mathrm{Ca}$ & [12] & [11] & [9] & [11] & [10] & {$[10]$} & [6] \\
\hline $\mathrm{Cd}$ & & & & & & & \\
\hline $\mathrm{Ce}$ & & & & & & & \\
\hline Co & & & & & & & \\
\hline $\mathrm{Cr}$ & 25 & 35 & 57 & 98 & 157 & 151 & 16 \\
\hline $\mathrm{Cu}$ & & & & & & & \\
\hline Dy & & & & & & & \\
\hline $\mathrm{Eu}$ & & & & & & & \\
\hline $\mathrm{Fe}$ & [1] & [1] & [1] & [1] & [1] & [2] & [0] \\
\hline $\mathrm{K}$ & & & & & & & \\
\hline $\mathrm{La}$ & & & & & & & \\
\hline $\mathrm{Li}$ & & & & & & & \\
\hline $\mathrm{Mg}$ & & & & & & & \\
\hline Mn & & & & & & & \\
\hline Mo & & & & & & & \\
\hline $\mathrm{Na}$ & 24855 & 25056 & 24870 & 25040 & 25942 & 24872 & 2950 \\
\hline $\mathrm{Nd}$ & & & & & & & \\
\hline $\mathrm{Ni}$ & [1] & [1] & [1] & [1] & [1] & [1] & [1] \\
\hline $\mathrm{P}$ & [13] & [14] & [15] & [15] & [16] & [16] & [3] \\
\hline $\mathrm{Pb}$ & & & & & & & \\
\hline $\mathrm{Pd}$ & & & & & & & \\
\hline $\mathrm{Rh}$ & & & & & & & \\
\hline $\mathrm{Ru}$ & & & & & & & \\
\hline $\mathrm{Sb}$ & & & & & & & \\
\hline $\mathrm{Se}$ & & & & & & & \\
\hline $\mathrm{Si}$ & [47] & [48] & [46] & [44] & [42] & [41] & [20] \\
\hline Sn & & & & & & & \\
\hline $\mathrm{Sr}$ & & & & & & & \\
\hline $\mathrm{Te}$ & & & & & & & \\
\hline Th & & & & & & & \\
\hline $\mathrm{Ti}$ & & & & & & & \\
\hline $\mathrm{Tl}$ & & & & & & & \\
\hline $\mathrm{U}$ & & & & & & & \\
\hline V & & & & & & & \\
\hline W & & & & & & & \\
\hline Y & & & & & & & \\
\hline $\mathrm{Zn}$ & & & & & & & \\
\hline $\mathrm{Zr}$ & & & & & & & \\
\hline
\end{tabular}


Table A.2. Component Concentrations As a Function of Time For Leaching of S-110 Solids With $3 \mathrm{M} \mathrm{NaOH}$ at $60^{\circ} \mathrm{C}$

\begin{tabular}{|c|c|c|c|c|c|c|c|}
\hline \multirow[b]{2}{*}{ Time, h: } & \multicolumn{7}{|c|}{ Concentration, $\mu \mathrm{g} / \mathrm{g}^{(\mathrm{a})}$} \\
\hline & 4 & 8 & 24 & 72 & 168 & 168 & Final Wash \\
\hline \multicolumn{8}{|l|}{$\mathrm{Ag}$} \\
\hline $\mathrm{Al}$ & 673 & 778 & 932 & 1267 & 1892 & 1870 & 139 \\
\hline \multicolumn{8}{|l|}{ As } \\
\hline \multicolumn{8}{|l|}{$\mathrm{B}$} \\
\hline \multicolumn{8}{|l|}{$\mathrm{Ba}$} \\
\hline \multicolumn{8}{|l|}{$\mathrm{Be}$} \\
\hline \multicolumn{8}{|l|}{$\mathrm{Bi}$} \\
\hline $\mathrm{Ca}$ & [9] & [9] & [11] & [11] & [10] & [9] & [6] \\
\hline \multicolumn{8}{|l|}{$\mathrm{Cd}$} \\
\hline \multicolumn{8}{|l|}{$\mathrm{Ce}$} \\
\hline \multicolumn{8}{|l|}{ Co } \\
\hline $\mathrm{Cr}$ & 36 & 49 & 83 & 139 & 200 & 198 & 15 \\
\hline \multicolumn{8}{|l|}{$\mathrm{Cu}$} \\
\hline \multicolumn{8}{|l|}{ Dy } \\
\hline \multicolumn{8}{|l|}{$\mathrm{Eu}$} \\
\hline $\mathrm{Fe}$ & [3] & [3] & [4] & [4] & [6] & [6] & [0] \\
\hline \multicolumn{8}{|l|}{ K } \\
\hline \multicolumn{8}{|l|}{$\mathrm{La}$} \\
\hline \multirow{2}{*}{\multicolumn{8}{|c|}{$\begin{array}{l}\mathrm{Li} \\
\mathrm{Mg}\end{array}$}} \\
\hline \multirow{2}{*}{\multicolumn{8}{|c|}{$\begin{array}{l}\mathrm{Mg} \\
\mathrm{Mn}\end{array}$}} \\
\hline & & & & & & & \\
\hline \multicolumn{8}{|l|}{ Mo } \\
\hline $\mathrm{Na}$ & 60354 & 64166 & 66551 & 65173 & 65867 & 65144 & 5040 \\
\hline \multicolumn{8}{|l|}{$\mathrm{Nd}$} \\
\hline $\mathrm{Ni}$ & {$[1]$} & [1] & [1] & {$[1]$} & [1] & [1] & [1] \\
\hline $\mathrm{P}$ & [16] & [15] & [15] & [15] & [15] & [16] & [2] \\
\hline $\mathrm{Pb}$ & {$[4]$} & [3] & [3] & {$[4]$} & [4] & [4] & \\
\hline \multicolumn{8}{|l|}{$\mathrm{Pd}$} \\
\hline \multicolumn{8}{|l|}{$\mathrm{Rh}$} \\
\hline $\mathrm{Ru}$ & & & & & & & \\
\hline $\mathrm{Sb}$ & & & & & & & \\
\hline $\mathrm{Se}$ & & & & & & & \\
\hline $\mathrm{Si}$ & [58] & [61] & [66] & [64] & [65] & [64] & [22] \\
\hline $\mathrm{Sn}$ & & & & & & & \\
\hline $\mathrm{Sr}$ & & & & & & & \\
\hline $\mathrm{Te}$ & & & & & & & \\
\hline Th & & & & & & & \\
\hline $\mathrm{Ti}$ & & & & & & & \\
\hline $\mathrm{Tl}$ & & & & & & & \\
\hline $\mathrm{U}$ & & & & & & & \\
\hline V & & & & & & & \\
\hline W & & & & & & & \\
\hline Y & & & & & & & \\
\hline $\mathrm{Zn}$ & {$[1]$} & [2] & [2] & {$[2]$} & [2] & {$[2]$} & \\
\hline $\mathrm{Zr}$ & 2 & 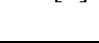 & & {$[-1$} & {$[-1$} & $L^{2}$ & \\
\hline
\end{tabular}


Table A.3. Component Concentrations As a Function of Time For Leaching of S-110 Solids With $5 \mathrm{M} \mathrm{NaOH}$ at $60^{\circ} \mathrm{C}$

\begin{tabular}{|c|c|c|c|c|c|c|c|}
\hline \multirow[b]{2}{*}{ Time, h: } & \multicolumn{7}{|c|}{ Concentration, $\mu \mathrm{g} / \mathrm{g}^{(\mathrm{a})}$} \\
\hline & 4 & 8 & 24 & 72 & 168 & 168 & Final Wash \\
\hline \multicolumn{8}{|l|}{$\mathrm{Ag}$} \\
\hline $\mathrm{Al}$ & 626 & 701 & 830 & 1201 & 1926 & 1896 & 203 \\
\hline \multicolumn{8}{|l|}{ As } \\
\hline \multicolumn{8}{|l|}{$\mathrm{B}$} \\
\hline \multicolumn{8}{|l|}{$\mathrm{Ba}$} \\
\hline \multicolumn{8}{|l|}{$\mathrm{Be}$} \\
\hline \multicolumn{8}{|l|}{$\mathrm{Bi}$} \\
\hline $\mathrm{Ca}$ & [8] & [11] & [10] & [10] & [12] & [11] & [5] \\
\hline \multicolumn{8}{|l|}{$\mathrm{Cd}$} \\
\hline \multicolumn{8}{|l|}{$\mathrm{Ce}$} \\
\hline \multicolumn{8}{|l|}{ Co } \\
\hline $\mathrm{Cr}$ & 36 & 53 & 94 & 162 & 220 & 215 & 23 \\
\hline \multicolumn{8}{|l|}{$\mathrm{Cu}$} \\
\hline \multicolumn{8}{|l|}{ Dy } \\
\hline \multicolumn{8}{|l|}{$\mathrm{Eu}$} \\
\hline $\mathrm{Fe}$ & [4] & [6] & [7] & [14] & [19] & [16] & \\
\hline K & [54] & [124] & [79] & [68] & & [64] & \\
\hline \multicolumn{8}{|l|}{$\mathrm{La}$} \\
\hline \multicolumn{8}{|c|}{$\mathrm{Li}$} \\
\hline \multicolumn{8}{|l|}{$\mathrm{Mg}$} \\
\hline \multicolumn{8}{|l|}{$\mathrm{Mn}$} \\
\hline \multicolumn{8}{|l|}{ Mo } \\
\hline $\mathrm{Na}$ & 88464 & 95649 & 94341 & 97723 & 97460 & 98280 & 10609 \\
\hline \multicolumn{8}{|l|}{$\mathrm{Nd}$} \\
\hline $\mathrm{Ni}$ & {$[1]$} & [2] & [2] & {$[3]$} & [1] & [1] & [1] \\
\hline $\mathrm{P}$ & [15] & [19] & [17] & [17] & [16] & [17] & [2] \\
\hline $\mathrm{Pb}$ & {$[4]$} & [6] & [6] & {$[6]$} & [4] & [5] & \\
\hline \multicolumn{8}{|l|}{$\mathrm{Pd}$} \\
\hline \multicolumn{8}{|l|}{$\mathrm{Rh}$} \\
\hline $\mathrm{Ru}$ & & & & & & & \\
\hline $\mathrm{Sb}$ & & & & & & & \\
\hline $\mathrm{Se}$ & & & & & & & \\
\hline $\mathrm{Si}$ & [51] & [62] & [61] & [63] & [66] & [64] & [24] \\
\hline $\mathrm{Sn}$ & & & & & & & \\
\hline $\mathrm{Sr}$ & & & & & & & \\
\hline $\mathrm{Te}$ & & & & & & & \\
\hline Th & & & & & & & \\
\hline $\mathrm{Ti}$ & & & & & & & \\
\hline $\mathrm{Tl}$ & & & & & & & \\
\hline $\mathrm{U}$ & & [75] & [57] & & & & \\
\hline V & & & & & & & \\
\hline W & & & & & & & \\
\hline Y & & & & & & & \\
\hline $\mathrm{Zn}$ & {$[1]$} & [2] & [3] & {$[2]$} & [3] & [2] & \\
\hline $\mathrm{Zr}$ & 2 & 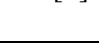 & 2. & & & $L^{2}$ & \\
\hline
\end{tabular}


Table A.4. Component Concentrations As a Function of Time For Leaching of S-110 Solids With $1 \mathrm{M} \mathrm{NaOH}$ at $80^{\circ} \mathrm{C}$

\begin{tabular}{|c|c|c|c|c|c|c|c|}
\hline \multirow[b]{2}{*}{ Time, h: } & \multicolumn{7}{|c|}{ Concentration, $\mu \mathrm{g} / \mathrm{g}^{(\mathrm{a})}$} \\
\hline & 4 & 8 & 24 & 72 & 168 & 168 & Final Wash \\
\hline \multicolumn{8}{|l|}{$\mathrm{Ag}$} \\
\hline $\mathrm{Al}$ & 758 & 1042 & 1699 & 2502 & 3003 & 3056 & 137 \\
\hline \multicolumn{8}{|l|}{ As } \\
\hline \multicolumn{8}{|l|}{ B } \\
\hline \multirow{2}{*}{\multicolumn{8}{|c|}{$\begin{array}{l}\mathrm{Ba} \\
\mathrm{Be}\end{array}$}} \\
\hline & & & & & & & \\
\hline \multicolumn{8}{|l|}{$\mathrm{Bi}$} \\
\hline $\mathrm{Ca}$ & [10] & [11] & [12] & [10] & [9] & [10] & {$[0]$} \\
\hline \multicolumn{8}{|l|}{$\mathrm{Cd}$} \\
\hline \multicolumn{8}{|l|}{$\mathrm{Ce}$} \\
\hline \multicolumn{8}{|l|}{ Co } \\
\hline $\mathrm{Cr}$ & [41] & 64 & 117 & 191 & 234 & 241 & 11 \\
\hline \multicolumn{8}{|l|}{$\mathrm{Cu}$} \\
\hline \multicolumn{8}{|l|}{ Dy } \\
\hline \multicolumn{8}{|l|}{$\mathrm{Eu}$} \\
\hline $\mathrm{Fe}$ & [1] & [1] & [4] & [2] & [2] & [2] & [1] \\
\hline \multicolumn{8}{|c|}{$\mathrm{K}$} \\
\hline \multicolumn{8}{|l|}{$\mathrm{La}$} \\
\hline \multicolumn{8}{|l|}{$\mathrm{Li}$} \\
\hline \multicolumn{8}{|l|}{$\mathrm{Mg}$} \\
\hline \multirow{2}{*}{\multicolumn{8}{|c|}{$\mathrm{Mn}$}} \\
\hline & & & & & & & \\
\hline $\mathrm{Na}$ & 20253 & 22867 & 23620 & 23158 & 22657 & 23084 & 1538 \\
\hline \multicolumn{8}{|l|}{$\mathrm{Nd}$} \\
\hline $\mathrm{Ni}$ & [1] & {$[1]$} & [2] & [1] & [1] & [1] & \\
\hline $\mathrm{P}$ & [12] & [15] & [19] & [16] & [16] & [17] & [2] \\
\hline \multicolumn{8}{|c|}{ [3] } \\
\hline \multirow{2}{*}{\multicolumn{8}{|c|}{$\begin{array}{l}\mathrm{Pd} \\
\mathrm{Rh}\end{array}$}} \\
\hline & & & & & & & \\
\hline $\mathrm{Ru}$ & & & & & & & \\
\hline $\mathrm{Sb}$ & & & & & & & \\
\hline $\mathrm{Se}$ & & & & & & & \\
\hline $\mathrm{Si}$ & [39] & [47] & [45] & [41] & [35] & [36] & [13] \\
\hline Sn & & & & & & & \\
\hline $\mathrm{Sr}$ & & & & & & & \\
\hline $\mathrm{Te}$ & & & & & & & \\
\hline Th & & & & & & & \\
\hline $\mathrm{Ti}$ & & & & & & & \\
\hline $\mathrm{Tl}$ & & & & & & & \\
\hline $\mathrm{U}$ & & & & & & & \\
\hline $\mathrm{V}$ & & & & & & & \\
\hline W & & & & & & & \\
\hline Y & & & & & & & \\
\hline $\mathrm{Zn}$ & & & [2] & {$[1]$} & [1] & [1] & \\
\hline $\mathrm{Zr}$ & & & & & & & \\
\hline
\end{tabular}


Table A.5. Component Concentrations As a Function of Time For Leaching of S-110 Solids With $3 \mathrm{M} \mathrm{NaOH}$ at $80^{\circ} \mathrm{C}$

Concentration, $\mu \mathrm{g} / \mathrm{g}^{(\mathrm{a})}$

\begin{tabular}{|c|c|c|c|c|c|c|c|}
\hline & & & & & & & \\
\hline Time, h: & 4 & 8 & 24 & 72 & 168 & 168 & Final Wash \\
\hline $\mathrm{Al}$ & 870 & 1029 & 1794 & 2907 & 3757 & 3786 & 186 \\
\hline As & & & & & & & \\
\hline B & & & & & & & \\
\hline $\mathrm{Ba}$ & & & & & & & \\
\hline $\mathrm{Be}$ & & & & & & & \\
\hline $\mathrm{Bi}$ & [6] & [7] & [7] & [7] & [7] & [15] & \\
\hline $\mathrm{Ca}$ & [11] & [12] & [10] & [12] & [11] & [14] & \\
\hline $\mathrm{Cd}$ & & & & & & & \\
\hline $\mathrm{Ce}$ & & & & & & & \\
\hline Co & & & & & & & \\
\hline $\mathrm{Cr}$ & 61 & 86 & 163 & 228 & 252 & 250 & 12 \\
\hline $\mathrm{Cu}$ & & & & & & & \\
\hline Dy & & & & & & & \\
\hline $\mathrm{Eu}$ & & & & & & & \\
\hline $\mathrm{Fe}$ & [4] & [4] & 7 & 11 & 9 & 16 & {$[0.5]$} \\
\hline $\mathrm{K}$ & [94] & [122] & [68] & [87] & [74] & [53] & \\
\hline $\mathrm{La}$ & & & & & & & \\
\hline $\mathrm{Li}$ & [1] & [1] & & & & & \\
\hline $\mathrm{Mg}$ & & & & & & & \\
\hline $\mathrm{Mn}$ & & & & & & & \\
\hline Mo & & & & & & & \\
\hline $\mathrm{Na}$ & 58860 & 57233 & 62592 & 60966 & 62258 & 62423 & 3681 \\
\hline $\mathrm{Nd}$ & & [3] & & & & & \\
\hline $\mathrm{Ni}$ & [1] & [1] & [1] & [1] & [1] & [4] & \\
\hline $\mathrm{P}$ & {$[16]$} & [16] & [16] & [18] & [18] & [25] & \\
\hline $\mathrm{Pb}$ & [4] & {$[5]$} & [4] & [5] & [5] & [4] & \\
\hline $\mathrm{Pd}$ & & & & & & & \\
\hline $\mathrm{Rh}$ & & & & & & & \\
\hline $\mathrm{Ru}$ & & & & & & & \\
\hline $\mathrm{Sb}$ & & & & & & & \\
\hline $\mathrm{Se}$ & & & & & & & \\
\hline $\mathrm{Si}$ & [65] & [65] & [65] & [65] & [66] & [65] & [14] \\
\hline Sn & & & & & & & \\
\hline $\mathrm{Sr}$ & & & & & & {$[0.5]$} & \\
\hline $\mathrm{Te}$ & & & & & & & \\
\hline Th & & & & & & & \\
\hline $\mathrm{Ti}$ & & & & & & & \\
\hline $\mathrm{Tl}$ & & & & & & & \\
\hline $\mathrm{U}$ & & [65] & & & & & \\
\hline V & & & & & & & \\
\hline W & & & & & & & \\
\hline Y & & & & & & & \\
\hline $\mathrm{Zn}$ & [2] & [2] & [2] & [2] & [2] & [2] & \\
\hline $\mathrm{Zr}$ & {$[-]$} & {$[-]$} & {$[-1$} & {$[-\pi$} & & {$[-]$} & \\
\hline
\end{tabular}


Table A.6. Component Concentrations As a Function of Time For Leaching of S-110 Solids With $5 \mathrm{M} \mathrm{NaOH}$ at $80^{\circ} \mathrm{C}$

Concentration, $\mu \mathrm{g} / \mathrm{g}^{(\mathrm{a})}$

\begin{tabular}{|c|c|c|c|c|c|c|c|}
\hline \multirow[b]{2}{*}{ Time, h: } & \\
\hline & 4 & 8 & 24 & 72 & 168 & 168 & Final Wash \\
\hline $\mathrm{Ag}$ & & & & & & & \\
\hline $\mathrm{Al}$ & 855 & 1032 & 1880 & 2911 & 3788 & 3670 & 178 \\
\hline As & & & & & & & \\
\hline B & & & & & & & [1] \\
\hline $\mathrm{Ba}$ & & & & & & & \\
\hline $\mathrm{Be}$ & & & & & & & \\
\hline $\mathrm{Bi}$ & [12] & [14] & [11] & [10] & [11] & [10] & \\
\hline $\mathrm{Ca}$ & [13] & [20] & [14] & [11] & [11] & {$[10]$} & [5] \\
\hline $\mathrm{Cd}$ & & & {$[0.5]$} & & {$[0.5]$} & {$[0.5]$} & \\
\hline $\mathrm{Ce}$ & & & & & & & \\
\hline Co & & & & & & & \\
\hline $\mathrm{Cr}$ & 58 & 87 & 178 & 214 & 239 & 230 & 11 \\
\hline $\mathrm{Cu}$ & & & & & & & \\
\hline Dy & & & & & & & \\
\hline Eu & & & & & & & \\
\hline $\mathrm{Fe}$ & 7 & 15 & 17 & 21 & 16 & 15 & \\
\hline $\mathrm{K}$ & [89] & & [92] & & [76] & [71] & \\
\hline $\mathrm{La}$ & & & & & & & \\
\hline $\mathrm{Li}$ & & & & & & & \\
\hline $\mathrm{Mg}$ & & & & & & & \\
\hline $\mathrm{Mn}$ & & & & & & & \\
\hline Mo & & & & & & & \\
\hline $\mathrm{Na}$ & 93933 & 88678 & 95900 & 93104 & 95229 & 89978 & 4953 \\
\hline $\mathrm{Nd}$ & & & [3] & & & & \\
\hline $\mathrm{Ni}$ & [3] & [4] & [2] & [2] & [1] & [1] & [1] \\
\hline $\mathrm{P}$ & [17] & [22] & [18] & [16] & [17] & [17] & \\
\hline $\mathrm{Pb}$ & [5] & [3] & [5] & [4] & [5] & [5] & \\
\hline $\mathrm{Pd}$ & & & & & & & \\
\hline $\mathrm{Rh}$ & & & & & & & \\
\hline $\mathrm{Ru}$ & & & & & & & \\
\hline $\mathrm{Sb}$ & & & & & & & \\
\hline $\mathrm{Se}$ & & & & & & & \\
\hline $\mathrm{Si}$ & [62] & [60] & [65] & [60] & [62] & [59] & [20] \\
\hline $\mathrm{Sn}$ & & & & & & & \\
\hline $\mathrm{Sr}$ & & & & [1] & [1] & [1] & \\
\hline $\mathrm{Te}$ & & & & & & & \\
\hline Th & & & & & & & \\
\hline $\mathrm{Ti}$ & & & & & & & \\
\hline $\mathrm{Tl}$ & & & & & & & \\
\hline $\mathrm{U}$ & & & [54] & & & & \\
\hline V & & & & & & & \\
\hline W & & & & & & & \\
\hline Y & & & & & & & \\
\hline $\mathrm{Zn}$ & [2] & [2] & [2] & [2] & [2] & [2] & \\
\hline $\mathrm{Zr}$ & & & & & & & \\
\hline
\end{tabular}


Table A.7. Component Concentrations As a Function of Time For Leaching of S-110 Solids With $1 \mathrm{M} \mathrm{NaOH}$ at $100^{\circ} \mathrm{C}$

\begin{tabular}{|c|c|c|c|c|c|c|c|}
\hline \multirow{3}{*}{$\begin{array}{l}\text { Time, h: } \\
\text { Ag }\end{array}$} & \multicolumn{7}{|c|}{ Concentration, $\mu \mathrm{g} / \mathrm{g}^{(\mathrm{a})}$} \\
\hline & \multirow{3}{*}{$\begin{array}{r}4 \\
1253\end{array}$} & \multirow[t]{2}{*}{8} & \multirow[t]{2}{*}{24} & \multirow[t]{2}{*}{72} & \multirow[t]{2}{*}{168} & \multirow[t]{2}{*}{168} & \multirow[t]{2}{*}{ Final Wash } \\
\hline & & & & & & & \\
\hline $\mathrm{Al}$ & & 1823 & 2781 & 3550 & 4087 & 4031 & 139 \\
\hline \multicolumn{8}{|l|}{ As } \\
\hline \multirow{2}{*}{\multicolumn{8}{|c|}{ B }} \\
\hline & & & & & & & \\
\hline \multicolumn{8}{|l|}{$\begin{array}{l}\mathrm{Da} \\
\mathrm{Be}\end{array}$} \\
\hline $\mathrm{Bi}$ & & [3] & [3] & [3] & [3] & [3] & {$[0]$} \\
\hline $\mathrm{Ca}$ & [11] & [11] & [13] & [9] & [11] & [9] & [5] \\
\hline \multicolumn{8}{|l|}{$\mathrm{Cd}$} \\
\hline \multicolumn{8}{|l|}{$\mathrm{Ce}$} \\
\hline \multicolumn{8}{|l|}{ Co } \\
\hline $\mathrm{Cr}$ & 71 & 108 & 187 & 242 & 268 & 263 & 9 \\
\hline \multicolumn{8}{|l|}{$\mathrm{Cu}$} \\
\hline \multirow{2}{*}{\multicolumn{8}{|c|}{ Dy }} \\
\hline $\mathrm{Eu}$ & & & & & & & \\
\hline $\mathrm{Fe}$ & [1] & [2] & [3] & [3] & [2] & [2] & \\
\hline \multicolumn{8}{|l|}{$\mathrm{K}$} \\
\hline \multicolumn{8}{|l|}{$\mathrm{La}$} \\
\hline \multicolumn{8}{|l|}{$\mathrm{Li}$} \\
\hline \multicolumn{8}{|l|}{$\mathrm{Mg}$} \\
\hline $\mathrm{Mn}$ & & & & & & & \\
\hline Mo & & & & & & & \\
\hline $\mathrm{Na}$ & 22078 & 22217 & 22577 & 22443 & 23002 & 22626 & 1544 \\
\hline $\mathrm{Nd}$ & & & & & & & \\
\hline $\mathrm{Ni}$ & [1] & [1] & [1] & {$[1]$} & [1] & [1] & [1] \\
\hline$P$ & [14] & {$[15]$} & [16] & [15] & {$[15]$} & {$[15]$} & \\
\hline $\mathrm{Pb}$ & & & [3] & & & [3] & \\
\hline Pd & & & & & & & \\
\hline $\mathrm{Rh}$ & & & & & & & \\
\hline $\mathrm{Ru}$ & & & & & & & \\
\hline $\mathrm{Sb}$ & & & & & & & \\
\hline $\mathrm{Se}$ & & & & & & & \\
\hline $\mathrm{Si}$ & [44] & [40] & {$[38]$} & [35] & [33] & [31] & [18] \\
\hline $\mathrm{Sn}$ & & & & & & & \\
\hline $\mathrm{Sr}$ & & & & & & & \\
\hline $\mathrm{Te}$ & & & & & & & \\
\hline Th & & & & & & & \\
\hline $\mathrm{Ti}$ & & & & & & & \\
\hline $\mathrm{Tl}$ & & & & & & & \\
\hline U & & & & & & & \\
\hline V & & & & & & & \\
\hline W & & & & & & & \\
\hline Y & & & & & & & \\
\hline $\mathrm{Zn}$ & [0] & [1] & [2] & [1] & [2] & [2] & {$[0]$} \\
\hline $\mathrm{Zr}$ & & & & & & & \\
\hline
\end{tabular}

(a) Analyte was below detection limit if left blank. Experimental uncertainties are 15\%, except for values given in brackets. Values given in brackets are within 10 times the detection limit and the uncertainties for these values are greater than $15 \%$. 
Table A.8. Component Concentrations As a Function of Time For Leaching of S-110 Solids With $3 \mathrm{M} \mathrm{NaOH}$ at $100^{\circ} \mathrm{C}$

Concentration, $\mu \mathrm{g} / \mathrm{g}^{(\mathrm{a})}$

\begin{tabular}{|c|c|c|c|c|c|c|c|}
\hline \multirow{2}{*}{ Time, h: } & & & & & & & \\
\hline & 4 & 8 & 24 & 72 & 168 & 168 & Final Wash \\
\hline $\begin{array}{l}\mathrm{Ag} \\
\mathrm{Al}\end{array}$ & 1428 & 2059 & 3186 & 4038 & 4167 & 4150 & 138 \\
\hline As & & & & & & & \\
\hline B & & & & & & & {$[0.2]$} \\
\hline $\mathrm{Ba}$ & & & & & & & \\
\hline $\mathrm{Be}$ & & & & & & & \\
\hline $\mathrm{Bi}$ & [7] & [7] & [8] & [8] & [8] & [7] & \\
\hline $\mathrm{Ca}$ & [10] & [11] & [12] & [11] & [10] & [9] & [6] \\
\hline $\mathrm{Cd}$ & & & & & & & \\
\hline $\mathrm{Ce}$ & & & & & & & \\
\hline Co & & & & & & & \\
\hline $\mathrm{Cr}$ & 95 & 151 & 224 & 257 & 266 & 263 & 9 \\
\hline $\mathrm{Cu}$ & & & & & & & \\
\hline Dy & & & & & & & \\
\hline $\mathrm{Eu}$ & & & & & & & \\
\hline $\mathrm{Fe}$ & [6] & 9 & 13 & 10 & 8 & 8 & \\
\hline K & [60] & [67] & [73] & [65] & [73] & [57] & \\
\hline $\mathrm{La}$ & & & & & & & \\
\hline $\mathrm{Li}$ & [1] & & & & & & \\
\hline $\mathrm{Mg}$ & & & & & & & \\
\hline $\mathrm{Mn}$ & & & & & & & \\
\hline Mo & & & & & & & \\
\hline $\mathrm{Na}$ & 57912 & 57804 & 58413 & 59718 & 60536 & 59519 & 2458 \\
\hline $\mathrm{Nd}$ & & & & & [3] & & \\
\hline $\mathrm{Ni}$ & [2] & [1] & [2] & [2] & [1] & [1] & [1] \\
\hline$P$ & [16] & [16] & [18] & [18] & [19] & [17] & \\
\hline $\mathrm{Pb}$ & [5] & [5] & [6] & [6] & [6] & [5] & \\
\hline$P d$ & & & & & & & \\
\hline $\mathrm{Rh}$ & & & & & & & \\
\hline $\mathrm{Ru}$ & & & & & & & \\
\hline $\mathrm{Sb}$ & & & & & & & \\
\hline $\mathrm{Se}$ & & & & & & & \\
\hline $\mathrm{Si}$ & [63] & [64] & [64] & [65] & [65] & [62] & [20] \\
\hline $\mathrm{Sn}$ & & & & & & & \\
\hline $\mathrm{Sr}$ & & & & [1] & [1] & {$[0.5]$} & \\
\hline $\mathrm{Te}$ & & & & & & & \\
\hline Th & & & & & & & \\
\hline $\mathrm{Ti}$ & & & & & & & \\
\hline $\mathrm{Tl}$ & & & & & & & \\
\hline $\mathrm{U}$ & & & & & & & \\
\hline V & & & & & & & \\
\hline W & & & & & & & \\
\hline Y & & & & & & & \\
\hline $\mathrm{Zn}$ & [2] & [2] & [2] & [2] & [3] & {$[2]$} & \\
\hline $\mathrm{Zr}$ & & & & & & & \\
\hline
\end{tabular}


Table A.9. Component Concentrations As a Function of Time For Leaching of S-110 Solids With $5 \mathrm{M} \mathrm{NaOH}$ at $100^{\circ} \mathrm{C}$

Concentration, $\mu \mathrm{g} / \mathrm{g}^{(\mathrm{a})}$

\begin{tabular}{|c|c|c|c|c|c|c|c|}
\hline & & & & & & & \\
\hline Time, h: & 4 & 8 & 24 & 72 & 168 & 168 & Final Wash \\
\hline $\begin{array}{l}\mathrm{Ag} \\
\mathrm{Al}\end{array}$ & 1462 & 2239 & 3499 & 3951 & 3891 & 4043 & 134 \\
\hline As & & & & & & & \\
\hline B & [5] & & & & & & [2] \\
\hline $\mathrm{Ba}$ & {$[0.3]$} & {$[0.3]$} & {$[0.2]$} & {$[0.3]$} & {$[0.3]$} & {$[0.2]$} & \\
\hline $\mathrm{Be}$ & & & & & & & \\
\hline $\mathrm{Bi}$ & [8] & [9] & [11] & [11] & [10] & [11] & \\
\hline $\mathrm{Ca}$ & [12] & [12] & [12] & [12] & {$[10]$} & {$[10]$} & [6] \\
\hline $\mathrm{Cd}$ & & & & & & {$[0.5]$} & \\
\hline $\mathrm{Ce}$ & & & & & & & \\
\hline Co & & & & & & & \\
\hline $\mathrm{Cr}$ & 82 & 142 & 237 & 254 & 252 & 259 & 9 \\
\hline $\mathrm{Cu}$ & & & & & & & \\
\hline Dy & & & & & & & \\
\hline $\mathrm{Eu}$ & & & & & & & \\
\hline $\mathrm{Fe}$ & [11] & [19] & [28] & [20] & {$[16]$} & [17] & \\
\hline K & [60] & [61] & [54] & & & [86] & \\
\hline $\mathrm{La}$ & & & & & & & \\
\hline $\mathrm{Li}$ & & & [1] & & & [1] & \\
\hline $\mathrm{Mg}$ & & & & & & & \\
\hline $\mathrm{Mn}$ & [3] & & & & & & \\
\hline Mo & & & & & & & \\
\hline $\mathrm{Na}$ & 88862 & 91087 & 95312 & 96808 & 95866 & 100544 & 3757 \\
\hline $\mathrm{Nd}$ & & & & & & [3] & \\
\hline $\mathrm{Ni}$ & [2] & [3] & [2] & [2] & [2] & [2] & [1] \\
\hline$P$ & [15] & [16] & [17] & [18] & [17] & [19] & \\
\hline $\mathrm{Pb}$ & [5] & [5] & [6] & [6] & [6] & [7] & \\
\hline $\mathrm{Pd}$ & & & & & & & \\
\hline $\mathrm{Rh}$ & & & & & & & \\
\hline $\mathrm{Ru}$ & & & & & & & \\
\hline $\mathrm{Sb}$ & & & & & & & \\
\hline $\mathrm{Se}$ & & & & & & & \\
\hline $\mathrm{Si}$ & [63] & [61] & [63] & [63] & [64] & [65] & [22] \\
\hline $\mathrm{Sn}$ & & & & & & & \\
\hline $\mathrm{Sr}$ & & & [1] & [1] & [1] & [1] & \\
\hline $\mathrm{Te}$ & & & & & & & \\
\hline Th & & & & & & & \\
\hline $\mathrm{Ti}$ & & & & & & & \\
\hline $\mathrm{Tl}$ & & & & & & & \\
\hline $\mathrm{U}$ & & & & & & [55] & \\
\hline V & & & & & & & \\
\hline W & & & & & & & \\
\hline Y & & & & & & & \\
\hline $\mathrm{Zn}$ & [2] & [2] & [2] & [3] & [3] & [3] & \\
\hline
\end{tabular}





\section{Appendix B}

\section{Leaching Results in Terms of Percent Component Removed}





\section{Appendix B: Leaching Results in Terms of Percent Component Removed}

Table B.1. Results of Leaching S- 110 Sludge With $1 \mathrm{M} \mathrm{NaOH}$ At $60^{\circ} \mathrm{C}$

\begin{tabular}{|c|c|c|c|c|c|c|c|c|c|c|c|}
\hline \multirow[b]{3}{*}{ Component } & \multicolumn{2}{|c|}{ Leaching Solution } & \multicolumn{2}{|c|}{ Washing Solution } & \multicolumn{2}{|c|}{ Leached Solids } & \multirow[b]{3}{*}{$\begin{array}{l}\text { Total } \\
\text { Mass, } \mu \mathrm{g}\end{array}$} & \multirow[b]{3}{*}{ Removed, \% } & \multirow[b]{3}{*}{$\begin{array}{l}\text { Calc. Conc. In } \\
\text { Washed Solids, } \mu \mathrm{g} / \mathrm{g}\end{array}$} & \multirow[b]{3}{*}{$\begin{array}{l}\text { Measured Conc. In } \\
\text { Washed Solids, } \mu \mathrm{g} / \mathrm{g}\end{array}$} & \multirow[b]{3}{*}{ Recovery \% } \\
\hline & Solution Mass, g: & 87.77 & Solution Mass, g: & 90.98 & Solids Mass, g: & 0.799 & & & & & \\
\hline & Conc., $\mu \mathrm{g} / \mathrm{g}$ & \multirow{2}{*}{ Mass, $\mu \mathrm{g}$} & \multirow{2}{*}{ Conc., $\mu \mathrm{g} / \mathrm{g}$} & \multirow{2}{*}{ Mass, $\mu \mathrm{g}$} & \multirow{2}{*}{ Conc., $\mu \mathrm{g} / \mathrm{g}$} & \multirow{2}{*}{ Mass, $\mu \mathrm{g}$} & & & & & \\
\hline $\mathrm{Ag}$ & & & & & & & & & & & \\
\hline $\mathrm{Al}$ & 1775 & 155819 & 178 & 16167 & 331800 & 265108 & 437094 & $39 \%$ & 367615 & 325000 & $113 \%$ \\
\hline As & & & & & [270] & {$[216]$} & [216] & (a) & [181] & & \\
\hline B & & & & & [76] & [61] & [61] & (a) & [51] & [135] & $38 \%$ \\
\hline $\mathrm{Ba}$ & & & & & 233 & 186 & 186 & (a) & 156 & [110] & $142 \%$ \\
\hline $\mathrm{Be}$ & & & & & & & & & & & \\
\hline $\mathrm{Bi}$ & & & & & 1865 & 1490 & 1490 & (a) & 1253 & 1365 & $92 \%$ \\
\hline $\mathrm{Ca}$ & [10] & [887] & [6] & [549] & [1420] & [1135] & [2571] & $56 \%$ & [2162] & [1200] & $180 \%$ \\
\hline $\mathrm{Cd}$ & & & & & [96] & [76] & {$[76]$} & (a) & {$[64]$} & {$[60]$} & $107 \%$ \\
\hline $\mathrm{Ce}$ & & & & & [215] & [172] & [172] & (a) & [144] & & \\
\hline Co & & & & & & & & & & & \\
\hline $\mathrm{Cr}$ & 154 & 13520 & 16 & 1418 & 19458 & 15547 & 30486 & $49 \%$ & 25640 & 23050 & $111 \%$ \\
\hline $\mathrm{Cu}$ & & & & & & & & & & {$[82]$} & $0 \%$ \\
\hline Dy & & & & & & & & & & & \\
\hline $\mathrm{Eu}$ & & & & & & & & & & & \\
\hline $\mathrm{Fe}$ & [2] & [137] & & & 21780 & 17402 & 17539 & $1 \%$ & 14751 & 14150 & $104 \%$ \\
\hline $\mathrm{K}$ & & & & & N/A & N/A & N/A & N/A & N/A & N/A & N/A \\
\hline $\mathrm{La}$ & & & & & [240] & [192] & [192] & (a) & {$[161]$} & [160] & $101 \%$ \\
\hline $\mathrm{Li}$ & & & & & [43] & [34] & [34] & (a) & [29] & & \\
\hline $\mathrm{Mg}$ & & & & & [480] & [384] & [384] & (a) & [323] & [380] & $85 \%$ \\
\hline $\mathrm{Mn}$ & & & & & 8305 & 6636 & 6636 & (a) & 5581 & 5305 & $105 \%$ \\
\hline Mo & & & & & & & & & & & \\
\hline $\mathrm{Na}$ & 25407 & 2229993 & 2950 & 268428 & 14250 & 11386 & 2509806 & N/A & N/A & N/A & N/A \\
\hline $\mathrm{Nd}$ & & & & & [260] & {$[208]$} & [208] & (a) & {$[175]$} & [345] & $51 \%$ \\
\hline $\mathrm{Ni}$ & [1] & {$[100]$} & [1] & [61] & $\mathrm{N} / \mathrm{A}$ & $\mathrm{N} / \mathrm{A}$ & N/A & N/A & N/A & $\mathrm{N} / \mathrm{A}$ & N/A \\
\hline $\mathrm{P}$ & [16] & [1423] & [3] & [305] & [250] & {$[200]$} & [1928] & $90 \%$ & {$[1621]$} & 1415 & $115 \%$ \\
\hline $\mathrm{Pb}$ & & & & & [465] & [372] & {$[372]$} & (a) & {$[312]$} & [595] & $53 \%$ \\
\hline $\mathrm{Pd}$ & & & & & & & & & & & \\
\hline $\mathrm{Rh}$ & & & & & & & & & & & \\
\hline $\mathrm{Ru}$ & & & & & & & & & & & \\
\hline $\mathrm{Sb}$ & & & & & & & & & & & \\
\hline $\mathrm{Se}$ & & & & & & & & & & & \\
\hline $\mathrm{Si}$ & [41] & {$[3620]$} & [20] & [1830] & [5120] & [4091] & [9541] & $57 \%$ & [8025] & {$[5500]$} & $146 \%$ \\
\hline Sn & & & & & & & & & & & \\
\hline $\mathrm{Sr}$ & & & & & 2090 & 1670 & 1670 & (a) & 1404 & 1240 & $113 \%$ \\
\hline $\mathrm{Te}$ & & & & & & & & & & & \\
\hline Th & & & & & & & & & & & \\
\hline $\mathrm{Ti}$ & & & & & [68] & [54] & [54] & (a) & [46] & [58] & $79 \%$ \\
\hline $\mathrm{Tl}$ & & & & & & & & & & & \\
\hline $\mathrm{U}$ & & & & & 30700 & 24529 & 24529 & (a) & 20630 & [23500] & $88 \%$ \\
\hline V & & & & & & & & & & & \\
\hline W & & & & & & & & & & & \\
\hline Y & & & & & [56] & [45] & [45] & (a) & [38] & & \\
\hline $\mathrm{Zn}$ & & & & & [270] & [216] & [216] & (a) & [181] & [225] & $81 \%$ \\
\hline $\mathrm{Zr}$ & & & & & [245] & {$[196]$} & [196] & (a) & {$[165]$} & {$[135]$} & $122 \%$ \\
\hline
\end{tabular}


Table B.2. Results of Leaching S-110 Sludge With $3 \mathrm{M} \mathrm{NaOH}$ At $60^{\circ} \mathrm{C}$

\begin{tabular}{|c|c|c|c|c|c|c|c|c|c|c|c|}
\hline \multirow[b]{3}{*}{ Component } & \multicolumn{2}{|c|}{ Leaching Solution } & \multicolumn{2}{|c|}{ Washing Solution } & \multicolumn{2}{|c|}{ Leached Solids } & \multirow[b]{3}{*}{$\begin{array}{l}\text { Total } \\
\text { Mass, } \mu \mathrm{g}\end{array}$} & \multirow[b]{3}{*}{ Removed, \% } & \multirow[b]{3}{*}{$\begin{array}{l}\text { Calc. Conc. In } \\
\text { Washed Solids, } \mu \mathrm{g} / \mathrm{g}\end{array}$} & \multirow[b]{3}{*}{$\begin{array}{l}\text { Measured Conc. In } \\
\text { Washed Solids, } \mu \mathrm{g} / \mathrm{g}\end{array}$} & \multirow[b]{3}{*}{ Recovery \% } \\
\hline & Solution Mass, g: & 98.066 & Solution Mass, g: & 90.345 & Solids Mass, g: & 0.671 & & & & & \\
\hline & \multirow{2}{*}{ Conc., $\mu \mathrm{g} / \mathrm{g}$} & \multirow{2}{*}{ Mass, $\mu \mathrm{g}$} & Conc., $\mu \mathrm{g} / \mathrm{g}$ & \multirow{2}{*}{ Mass, $\mu \mathrm{g}$} & \multirow{2}{*}{ Conc., $\mu \mathrm{g} / \mathrm{g}$} & \multirow{2}{*}{ Mass, $\mu \mathrm{g}$} & & & & & \\
\hline $\mathrm{Ag}$ & & & & & & & & & & & \\
\hline $\mathrm{Al}$ & 1881 & 184459 & 139 & 12549 & 334800 & 224651 & 421659 & $47 \%$ & 359470 & 325000 & $111 \%$ \\
\hline As & & & & & [290] & {$[195]$} & [195] & (a) & {$[166]$} & & \\
\hline B & & & & & {$[66]$} & [44] & [44] & (a) & {$[38]$} & [135] & $28 \%$ \\
\hline $\mathrm{Ba}$ & & & & & 263 & 176 & 176 & (a) & 150 & [110] & $137 \%$ \\
\hline $\mathrm{Be}$ & & & & & & & & & & & \\
\hline $\mathrm{Bi}$ & & & & & 1590 & 1067 & 1067 & (a) & 910 & 1365 & $67 \%$ \\
\hline $\mathrm{Ca}$ & & & [6] & [520] & [1670] & [1121] & [1641] & $32 \%$ & [1399] & {$[1200]$} & $117 \%$ \\
\hline $\mathrm{Cd}$ & & & & & [98] & [66] & {$[66]$} & (a) & {$[56]$} & {$[60]$} & $93 \%$ \\
\hline $\mathrm{Ce}$ & & & & & [240] & [161] & [161] & (a) & {$[137]$} & & \\
\hline Co & & & & & [50] & [34] & {$[34]$} & (a) & [29] & & \\
\hline $\mathrm{Cr}$ & 199 & 19547 & 15 & 1349 & 13158 & 8829 & 29725 & $70 \%$ & 25341 & 23050 & $110 \%$ \\
\hline $\mathrm{Cu}$ & & & & & 943 & 633 & 633 & (a) & 539 & {$[82]$} & $658 \%$ \\
\hline Dy & & & & & & & & & & & \\
\hline $\mathrm{Eu}$ & & & & & & & & & & & \\
\hline $\mathrm{Fe}$ & [6] & [629] & & & 25030 & 16795 & 17425 & $4 \%$ & 14855 & 14150 & $105 \%$ \\
\hline $\mathrm{K}$ & & & & & N/A & $\mathrm{N} / \mathrm{A}$ & N/A & $\mathrm{N} / \mathrm{A}$ & $\mathrm{N} / \mathrm{A}$ & $\mathrm{N} / \mathrm{A}$ & N/A \\
\hline $\mathrm{La}$ & & & & & {$[260]$} & [174] & [174] & (a) & [149] & [160] & $93 \%$ \\
\hline $\mathrm{Li}$ & & & & & [40] & [27] & {$[27]$} & (a) & [23] & & \\
\hline $\mathrm{Mg}$ & & & & & [570] & [382] & [382] & (a) & {$[326]$} & [380] & $86 \%$ \\
\hline $\mathrm{Mn}$ & & & & & 9420 & 6321 & 6321 & (a) & 5389 & 5305 & $102 \%$ \\
\hline Mo & & & & & [47] & [32] & [32] & (a) & [27] & & \\
\hline $\mathrm{Na}$ & 65506 & 6423897 & 5040 & 455309 & 4000 & 2684 & 6881890 & N/A & N/A & N/A & N/A \\
\hline $\mathrm{Nd}$ & & & & & [280] & [188] & [188] & (a) & {$[160]$} & [345] & $46 \%$ \\
\hline $\mathrm{Ni}$ & [1] & [105] & [1] & [56] & N/A & N/A & N/A & N/A & N/A & N/A & N/A \\
\hline $\mathrm{P}$ & {$[15]$} & [1506] & [2] & [183] & {$[210]$} & [141] & [1830] & $92 \%$ & {$[1560]$} & 1415 & $110 \%$ \\
\hline $\mathrm{Pb}$ & [4] & {$[367]$} & & & {$[380]$} & [255] & {$[622]$} & $59 \%$ & {$[530]$} & [595] & $89 \%$ \\
\hline $\mathrm{Pd}$ & & & & & & & & & & & \\
\hline $\mathrm{Rh}$ & & & & & & & & & & & \\
\hline $\mathrm{Ru}$ & & & & & & & & & & & \\
\hline $\mathrm{Sb}$ & & & & & & & & & & & \\
\hline $\mathrm{Se}$ & & & & & & & & & & & \\
\hline $\mathrm{Si}$ & [64] & [6294] & {$[22]$} & [1967] & [2300] & {$[1543]$} & [9805] & $84 \%$ & [8358] & {$[5500]$} & $152 \%$ \\
\hline Sn & & & & & & & & & & & \\
\hline $\mathrm{Sr}$ & & & & & 2360 & 1584 & 1584 & (a) & 1350 & 1240 & $109 \%$ \\
\hline $\mathrm{Te}$ & & & & & & & & & & & \\
\hline Th & & & & & & & & & & & \\
\hline $\mathrm{Ti}$ & & & & & [85] & [57] & [57] & (a) & [49] & [58] & $84 \%$ \\
\hline $\mathrm{Tl}$ & & & & & & & & & & & \\
\hline U & & & & & 34600 & 23217 & 23217 & (a) & 19792 & [23500] & $84 \%$ \\
\hline V & & & & & & & & & & & \\
\hline W & & & & & & & & & & & \\
\hline Y & & & & & [61] & [41] & [41] & (a) & [35] & & \\
\hline $\mathrm{Zn}$ & [2] & [184] & & & 1010 & 678 & 862 & $21 \%$ & 735 & [225] & $326 \%$ \\
\hline $\mathrm{Zr}$ & & & & & {$[230]$} & {$[154]$} & {$[154]$} & (a) & [132] & [135] & $97 \%$ \\
\hline
\end{tabular}


Table B.3. Results of Leaching S-110 Sludge With $5 \mathrm{M} \mathrm{NaOH}$ At $60^{\circ} \mathrm{C}$

\begin{tabular}{|c|c|c|c|c|c|c|c|c|c|c|c|}
\hline \multirow[b]{3}{*}{ Component } & \multicolumn{2}{|c|}{ Leaching Solution } & \multicolumn{2}{|c|}{ Washing Solution } & \multicolumn{2}{|c|}{ Leached Solids } & \multirow[b]{3}{*}{$\begin{array}{l}\text { Total } \\
\text { Mass, } \mu \mathrm{g}\end{array}$} & \multirow[b]{3}{*}{ Removed, \% } & \multirow[b]{3}{*}{$\begin{array}{l}\text { Calc. Conc. In } \\
\text { Washed Solids, } \mu \mathrm{g} / \mathrm{g}\end{array}$} & \multirow[b]{3}{*}{$\begin{array}{l}\text { Measured Conc. In } \\
\text { Washed Solids, } \mu \mathrm{g} / \mathrm{g}\end{array}$} & \multirow[b]{3}{*}{ Recovery \% } \\
\hline & Solution Mass, g: & 98.896 & Solution Mass, g: & 93.136 & Solids Mass, g: & $\overline{0.598}$ & & & & & \\
\hline & Conc., $\mu \mathrm{g} / \mathrm{g}$ & \multirow[t]{2}{*}{ Mass, $\mu \mathrm{g}$} & Conc., $\mu \mathrm{g} / \mathrm{g}$ & Mass, $\mu \mathrm{g}$ & \multirow[t]{2}{*}{ Conc., $\mu \mathrm{g} / \mathrm{g}$} & \multirow[t]{2}{*}{ Mass, $\mu \mathrm{g}$} & & & & & \\
\hline$\overline{\mathrm{Ag}}$ & & & & & & & & & & & \\
\hline $\mathrm{Al}$ & 1911 & 188989 & 203 & 18882 & 343800 & 205592 & 413463 & $50 \%$ & 357049 & 325000 & $110 \%$ \\
\hline As & & & & & {$[300]$} & [179] & [179] & (a) & {$[155]$} & & \\
\hline B & & & & & [82] & [49] & [49] & (a) & [42] & [135] & $31 \%$ \\
\hline $\mathrm{Ba}$ & & & & & 300 & 179 & 179 & (a) & 155 & [110] & $141 \%$ \\
\hline $\mathrm{Be}$ & & & & & & & & & & & \\
\hline $\mathrm{Bi}$ & & & & & 1290 & 771 & 771 & (a) & 666 & 1365 & $49 \%$ \\
\hline $\mathrm{Ca}$ & [11] & [1114] & [5] & [497] & [1570] & [939] & [2550] & $63 \%$ & [2202] & {$[1200]$} & $183 \%$ \\
\hline $\mathrm{Cd}$ & & & & & [84] & {$[50]$} & [50] & (a) & [43] & {$[60]$} & $72 \%$ \\
\hline $\mathrm{Ce}$ & & & & & {$[250]$} & {$[150]$} & {$[150]$} & (a) & [129] & & \\
\hline Co & & & & & & & & & & & \\
\hline $\mathrm{Cr}$ & 218 & 21525 & 23 & 2158 & 9168 & 5482 & 29165 & $81 \%$ & 25186 & 23050 & $109 \%$ \\
\hline $\mathrm{Cu}$ & & & & & & & & & & {$[82]$} & $0 \%$ \\
\hline Dy & & & & & & & & & & & \\
\hline $\mathrm{Eu}$ & & & & & & & & & & & \\
\hline $\mathrm{Fe}$ & [17] & [1715] & & & 25630 & 15327 & 17042 & $10 \%$ & 14716 & 14150 & $104 \%$ \\
\hline $\mathrm{K}$ & & & & & N/A & N/A & N/A & $\mathrm{N} / \mathrm{A}$ & N/A & N/A & N/A \\
\hline $\mathrm{La}$ & & & & & [290] & [173] & {$[173]$} & (a) & {$[150]$} & [160] & $94 \%$ \\
\hline $\mathrm{Li}$ & & & & & [40] & {$[24]$} & [24] & (a) & [21] & & \\
\hline $\mathrm{Mg}$ & & & & & [650] & [389] & [389] & (a) & [336] & [380] & $88 \%$ \\
\hline $\mathrm{Mn}$ & & & & & 10400 & 6219 & 6219 & (a) & 5371 & 5305 & $101 \%$ \\
\hline Mo & & & & & & & & & & & \\
\hline $\mathrm{Na}$ & 97870 & 9678935 & 10609 & 988098 & 9500 & 5681 & 10672715 & N/A & N/A & N/A & N/A \\
\hline $\mathrm{Nd}$ & & & & & [330] & [197] & [197] & (a) & [170] & [345] & $49 \%$ \\
\hline $\mathrm{Ni}$ & [1] & [111] & [1] & [57] & $\mathrm{N} / \mathrm{A}$ & N/A & N/A & N/A & $\mathrm{N} / \mathrm{A}$ & N/A & N/A \\
\hline $\mathrm{P}$ & [16] & [1631] & [2] & [170] & [200] & [120] & [1921] & $94 \%$ & [1659] & 1415 & $117 \%$ \\
\hline $\mathrm{Pb}$ & [4] & {$[430]$} & & & {$[300]$} & [179] & [609] & $71 \%$ & {$[526]$} & [595] & $88 \%$ \\
\hline $\mathrm{Pd}$ & & & & & & & & & & & \\
\hline $\mathrm{Rh}$ & & & & & & & & & & & \\
\hline $\mathrm{Ru}$ & & & & & & & & & & & \\
\hline $\mathrm{Sb}$ & & & & & & & & & & & \\
\hline $\mathrm{Se}$ & & & & & & & & & & & \\
\hline $\mathrm{Si}$ & [65] & [6432] & [24] & [2271] & [2000] & [1196] & [9900] & $88 \%$ & [8549] & {$[5500]$} & $155 \%$ \\
\hline Sn & & & & & & & & & & & \\
\hline $\mathrm{Sr}$ & & & & & 2620 & 1567 & 1567 & (a) & 1353 & 1240 & $109 \%$ \\
\hline $\mathrm{Te}$ & & & & & & & & & & & \\
\hline Th & & & & & & & & & & & \\
\hline $\mathrm{Ti}$ & & & & & [92] & [55] & [55] & (a) & {$[48]$} & [58] & $82 \%$ \\
\hline $\mathrm{Tl}$ & & & & & & & & & & & \\
\hline U & & & & & 38400 & 22963 & 22963 & (a) & 19830 & [23500] & $84 \%$ \\
\hline V & & & & & & & & & & & \\
\hline W & & & & & & & & & & & \\
\hline Y & & & & & [66] & [39] & [39] & (a) & [34] & & \\
\hline $\mathrm{Zn}$ & [3] & [249] & & & [220] & [132] & [381] & $65 \%$ & [329] & [225] & $146 \%$ \\
\hline $\mathrm{Zr}$ & & & & & {$[260]$} & {$[155]$} & {$[155]$} & (a) & [134] & [135] & $99 \%$ \\
\hline
\end{tabular}


Table B.4. Results of Leaching S-110 Sludge With $1 \mathrm{M} \mathrm{NaOH}$ At $80^{\circ} \mathrm{C}$

\begin{tabular}{|c|c|c|c|c|c|c|c|c|c|c|c|}
\hline \multirow[b]{3}{*}{ Component } & \multicolumn{2}{|c|}{ Leaching Solution } & \multicolumn{2}{|c|}{ Washing Solution } & \multicolumn{2}{|c|}{ Leached Solids } & \multirow[b]{3}{*}{$\begin{array}{l}\text { Total } \\
\text { Mass, } \mu \mathrm{g}\end{array}$} & \multirow[b]{3}{*}{ Removed, \% } & \multirow[b]{3}{*}{$\begin{array}{l}\text { Calc. Conc. In } \\
\text { Washed Solids, } \mu \mathrm{g} / \mathrm{g}\end{array}$} & \multirow[b]{3}{*}{$\begin{array}{l}\text { Measured Conc. In } \\
\text { Washed Solids, } \mu \mathrm{g} / \mathrm{g}\end{array}$} & \multirow[b]{3}{*}{ Recovery \% } \\
\hline & Solution Mass, g: & 90.105 & Solution Mass, g: & 86.262 & Solids Mass, g: & 0.423 & & & & & \\
\hline & Conc., $\mu \mathrm{g} / \mathrm{g}$ & \multirow[t]{2}{*}{ Mass, $\mu \mathrm{g}$} & Conc., $\mu \mathrm{g} / \mathrm{g}$ & \multirow[t]{2}{*}{ Mass, $\mu \mathrm{g}$} & Conc., $\mu \mathrm{g} / \mathrm{g}$ & Mass, $\mu \mathrm{g}$ & & & & & \\
\hline $\mathrm{Ag}$ & & & & & {$[25]$} & $\frac{[11]}{3}$ & {$[11]$} & (a) & {$[9]$} & & \\
\hline $\mathrm{Al}$ & 3029 & 272961 & 137 & 11833 & 299800 & 126815 & 411609 & $69 \%$ & 353010 & 325000 & $109 \%$ \\
\hline As & & & & & {$[320]$} & {$[135]$} & {$[135]$} & (a) & {$[116]$} & & \\
\hline B & & & & & {$[66]$} & [28] & [28] & (a) & [24] & [135] & $18 \%$ \\
\hline $\mathrm{Ba}$ & & & & & 417 & 176 & 176 & (a) & 151 & [110] & $138 \%$ \\
\hline \multicolumn{12}{|l|}{$\mathrm{Be}$} \\
\hline $\mathrm{Bi}$ & & & & & 3140 & 1328 & 1328 & (a) & 1139 & 1365 & $83 \%$ \\
\hline $\mathrm{Ca}$ & [10] & [886] & & & 3130 & 1324 & 2210 & $40 \%$ & [1895] & {$[1200]$} & $158 \%$ \\
\hline $\mathrm{Cd}$ & & & & & 163 & 69 & 69 & (a) & [59] & [60] & $99 \%$ \\
\hline $\mathrm{Ce}$ & & & & & [420] & [178] & [178] & (a) & {$[152]$} & & \\
\hline Co & & & & & {$[50]$} & [21] & [21] & (a) & 18 & & \\
\hline $\mathrm{Cr}$ & 238 & 21408 & 11 & 940 & 14558 & 6158 & 28506 & $78 \%$ & 24448 & 23050 & $106 \%$ \\
\hline $\mathrm{Cu}$ & & & & & & & & & & {$[82]$} & $0 \%$ \\
\hline \multicolumn{12}{|l|}{ Dy } \\
\hline \multicolumn{12}{|l|}{$\mathrm{Eu}$} \\
\hline $\mathrm{Fe}$ & [2] & [197] & & & 37730 & 15960 & 16157 & $1 \%$ & 13856 & 14150 & $98 \%$ \\
\hline $\mathrm{K}$ & & & & & & $\mathrm{N} / \mathrm{A}$ & N/A & $\mathrm{N} / \mathrm{A}$ & $\mathrm{N} / \mathrm{A}$ & N/A & N/A \\
\hline $\mathrm{La}$ & & & & & [460] & [195] & [195] & (a) & [167] & {$[160]$} & $104 \%$ \\
\hline $\mathrm{Li}$ & & & & & {$[66]$} & {$[28]$} & {$[28]$} & (a) & [24] & & \\
\hline $\mathrm{Mg}$ & & & & & [940] & [398] & [398] & (a) & [341] & [380] & $90 \%$ \\
\hline $\mathrm{Mn}$ & & & & & 14800 & 6260 & 6260 & (a) & 5369 & 5305 & $101 \%$ \\
\hline \multicolumn{12}{|c|}{ Mo } \\
\hline $\mathrm{Na}$ & 22871 & 2060757 & 1538 & 132704 & 22600 & 9560 & 2203021 & N/A & N/A & $\mathrm{N} / \mathrm{A}$ & N/A \\
\hline $\mathrm{Nd}$ & & & & & 580 & 245 & 245 & (a) & [210] & [345] & $61 \%$ \\
\hline $\mathrm{Ni}$ & [1] & {$[111]$} & {$[0]$} & [0] & 0 & $\mathrm{~N} / \mathrm{A}$ & $\mathrm{N} / \mathrm{A}$ & N/A & N/A & N/A & N/A \\
\hline $\mathrm{P}$ & [16] & [1476] & [2] & {$[180]$} & 330 & 140 & 1795 & $92 \%$ & {$[1540]$} & 1415 & $109 \%$ \\
\hline $\mathrm{Pb}$ & & & & & 710 & 300 & 300 & (a) & {$[258]$} & [595] & $43 \%$ \\
\hline $\mathrm{Pd}$ & & & & & & & & & & & \\
\hline $\mathrm{Rh}$ & & & & & & & & & & & \\
\hline $\mathrm{Ru}$ & & & & & & & & & & & \\
\hline $\mathrm{Sb}$ & & & & & & & & & & & \\
\hline $\mathrm{Se}$ & & & & & & & & & & & \\
\hline $\mathrm{Si}$ & [35] & [3197] & [13] & [1092] & 9600 & 4061 & 8350 & $51 \%$ & [7161] & {$[5500]$} & $130 \%$ \\
\hline Sn & & & & & & & & & & & \\
\hline $\mathrm{Sr}$ & & & & & 3800 & 1607 & 1607 & (a) & 1379 & 1240 & $111 \%$ \\
\hline $\mathrm{Te}$ & & & & & & & & & & & \\
\hline Th & & & & & & & & & & & \\
\hline $\mathrm{Ti}$ & & & & & {$[120]$} & [51] & [51] & (a) & [44] & [58] & $75 \%$ \\
\hline $\mathrm{Tl}$ & & & & & & & & & & & \\
\hline $\mathrm{U}$ & & & & & 55500 & 23477 & 23477 & (a) & 20134 & {$[23500]$} & $86 \%$ \\
\hline V & & & & & & & & & & & \\
\hline W & & & & & & & & & & & \\
\hline $\mathrm{Y}$ & & & & & {$[100]$} & [42] & [42] & (a) & [36] & & \\
\hline $\mathrm{Zn}$ & & & & & [440] & {$[186]$} & [186] & (a) & {$[160]$} & [225] & $71 \%$ \\
\hline $\mathrm{Zr}$ & & & & & [490] & {$[207]$} & [207] & (a) & {$[178]$} & {$[135]$} & $132 \%$ \\
\hline
\end{tabular}

(a) No detectable removal. 
Table B.5. Results of Leaching S-110 Sludge With $3 \mathrm{M} \mathrm{NaOH}$ At $80^{\circ} \mathrm{C}$

\begin{tabular}{|c|c|c|c|c|c|c|c|c|c|c|c|}
\hline \multirow[b]{3}{*}{ Component } & \multicolumn{2}{|c|}{ Leaching Solution } & \multicolumn{2}{|c|}{ Washing Solution } & \multicolumn{2}{|c|}{ Leached Solids } & \multirow[b]{3}{*}{ Total } & \multirow[b]{3}{*}{ Removed, \% } & \multirow[b]{3}{*}{$\begin{array}{l}\text { Calc. Conc. In } \\
\text { Washed Solids, } \mu \mathrm{g} / \mathrm{g}\end{array}$} & \multirow[b]{3}{*}{$\begin{array}{l}\text { Measured Conc. In } \\
\text { Washed Solids, } \mu \mathrm{g} / \mathrm{g}\end{array}$} & \multirow[b]{3}{*}{ Recovery \% } \\
\hline & \multirow{2}{*}{$\begin{array}{l}\text { Solution Mass, g: } \\
\text { Conc., } \mu \mathrm{g} / \mathrm{g}\end{array}$} & \multirow{2}{*}{$\begin{array}{r}99.177 \\
\text { Mass, } \mu \mathrm{g}\end{array}$} & \multirow{2}{*}{$\begin{array}{l}\text { Solution Mass, g: } \\
\text { Conc., } \mu \mathrm{g} / \mathrm{g}\end{array}$} & \multirow{2}{*}{$\begin{array}{l}87.325 \\
\text { Mass, } \mu \mathrm{g}\end{array}$} & \multirow{2}{*}{$\begin{array}{l}\text { Solids Mass, g: } \\
\text { Conc., } \mu \mathrm{g} / \mathrm{g}\end{array}$} & $\overline{0.207}$ & & & & & \\
\hline & & & & & & Mass, $\mu \mathrm{g}$ & & & & & \\
\hline$\overline{\mathrm{Ag}}$ & & & & & {$[41]$} & {$[8]$} & {$[8]$} & (a) & {$[7]$} & & \\
\hline $\mathrm{Al}$ & 3771 & 374041 & 186 & 16285 & 192800 & 39910 & 430235 & $91 \%$ & 371533 & 325000 & $114 \%$ \\
\hline As & & & & & {$[260]$} & {$[54]$} & [54] & (a) & [46] & & \\
\hline B & & & & & [91] & [19] & [19] & (a) & [16] & [135] & $12 \%$ \\
\hline $\mathrm{Ba}$ & & & & & 844 & 175 & 175 & (a) & 151 & [110] & $137 \%$ \\
\hline \multicolumn{12}{|l|}{$\mathrm{Be}$} \\
\hline $\mathrm{Bi}$ & & & & & 4580 & 948 & 948 & (a) & 819 & 1365 & $60 \%$ \\
\hline $\mathrm{Ca}$ & & & & & 6050 & 1252 & 1252 & (a) & 1081 & {$[1200]$} & $90 \%$ \\
\hline $\mathrm{Cd}$ & & & & & 286 & 59 & 59 & (a) & 51 & {$[60]$} & $85 \%$ \\
\hline $\mathrm{Ce}$ & & & & & [800] & [166] & [166] & (a) & [143] & & \\
\hline Co & & & & & [79] & [16] & {$[16]$} & (a) & [14] & & \\
\hline $\mathrm{Cr}$ & 251 & 24893 & 12 & 1090 & 16158 & 3345 & 29328 & $89 \%$ & 25326 & 23050 & $110 \%$ \\
\hline \multirow{2}{*}{\multicolumn{12}{|c|}{$\begin{array}{l}\mathrm{Cu} \\
\mathrm{Dy}\end{array}$}} \\
\hline & & & & & & & & & & & \\
\hline \multicolumn{12}{|l|}{$\mathrm{Eu}$} \\
\hline $\mathrm{Fe}$ & [13] & [1257] & & & 76130 & 15759 & 17016 & $7 \%$ & 14694 & 14150 & $104 \%$ \\
\hline $\mathrm{K}$ & & & & & N/A & N/A & N/A & N/A & N/A & N/A & N/A \\
\hline $\mathrm{La}$ & & & & & 890 & 184 & 184 & (a) & 159 & [160] & $99 \%$ \\
\hline $\mathrm{Li}$ & & & & & {$[100]$} & [21] & [21] & (a) & [18] & & \\
\hline $\mathrm{Mg}$ & & & & & 1940 & 402 & 402 & (a) & 347 & [380] & $91 \%$ \\
\hline $\mathrm{Mn}$ & & & & & 30100 & 6231 & 6231 & (a) & 5381 & 5305 & $101 \%$ \\
\hline \multicolumn{12}{|l|}{ Mo } \\
\hline $\mathrm{Na}$ & 62340 & 6182727 & 3681 & 321448 & 24800 & 5134 & 6509308 & N/A & N/A & N/A & N/A \\
\hline $\mathrm{Nd}$ & & & & & 1260 & 261 & 261 & (a) & 225 & [345] & $65 \%$ \\
\hline $\mathrm{Ni}$ & [3] & [254] & & & N/A & N/A & N/A & N/A & N/A & N/A & N/A \\
\hline $\mathrm{P}$ & [21] & [2116] & & & [300] & [62] & [2178] & $97 \%$ & [1881] & 1415 & $133 \%$ \\
\hline $\mathrm{Pb}$ & [4] & {$[430]$} & & & 880 & 182 & 612 & $70 \%$ & {$[529]$} & [595] & $89 \%$ \\
\hline $\mathrm{Pd}$ & & & & & [770] & [159] & [159] & (a) & {$[138]$} & & \\
\hline $\mathrm{Rh}$ & & & & & & & & & & & \\
\hline $\mathrm{Ru}$ & & & & & & & & & & & \\
\hline $\mathrm{Sb}$ & & & & & & & & & & & \\
\hline $\mathrm{Se}$ & & & & & & & & & & & \\
\hline $\mathrm{Si}$ & [66] & [6496] & [14] & [1204] & 5520 & 1143 & 8843 & $87 \%$ & {$[7636]$} & [5500] & $139 \%$ \\
\hline Sn & & & & & & & & & & & \\
\hline $\mathrm{Sr}$ & & & & & 7480 & 1548 & 1548 & (a) & 1337 & 1240 & $108 \%$ \\
\hline $\mathrm{Te}$ & & & & & & & & & & & \\
\hline Th & & & & & & & & & & & \\
\hline $\mathrm{Ti}$ & & & & & [220] & [46] & [46] & (a) & [39] & [58] & $68 \%$ \\
\hline $\mathrm{Tl}$ & & & & & & & & & & & \\
\hline U & & & & & 114800 & 23764 & 23764 & (a) & 20521 & [23500] & $87 \%$ \\
\hline V & & & & & & & & & & & \\
\hline W & & & & & & & & & & & \\
\hline Y & & & & & [200] & [41] & [41] & (a) & [36] & & \\
\hline $\mathrm{Zn}$ & [2] & & & & 562 & 116 & 116 & (a) & {$[100]$} & [225] & $45 \%$ \\
\hline $\mathrm{Zr}$ & & & & & 938 & 194 & 194 & (a) & {$[168]$} & [135] & $124 \%$ \\
\hline
\end{tabular}


Table B.6. Results of Leaching S-110 Sludge With $5 \mathrm{M} \mathrm{NaOH}$ At $80^{\circ} \mathrm{C}$

\begin{tabular}{|c|c|c|c|c|c|c|c|c|c|c|c|}
\hline \multirow[b]{3}{*}{ Component } & \multicolumn{2}{|c|}{ Leaching Solution } & \multicolumn{2}{|c|}{ Washing Solution } & \multicolumn{2}{|c|}{ Leached Solids } & \multirow[b]{3}{*}{ Total } & \multirow[b]{3}{*}{ Removed, \% } & \multirow[b]{3}{*}{$\begin{array}{l}\text { Calc. Conc. In } \\
\text { Washed Solids, } \mu \mathrm{g} / \mathrm{g}\end{array}$} & \multirow[b]{3}{*}{$\begin{array}{l}\text { Measured Conc. In } \\
\text { Washed Solids, } \mu \mathrm{g} / \mathrm{g}\end{array}$} & \multirow[b]{3}{*}{ Recovery \% } \\
\hline & Solution Mass, g: & 105.547 & Solution Mass, g: & 86.46 & Solids Mass, g: & $\overline{0.143}$ & & & & & \\
\hline & \multirow[t]{2}{*}{ Conc., $\mu \mathrm{g} / \mathrm{g}$} & \multirow[t]{2}{*}{ Mass, $\mu \mathrm{g}$} & & \multirow[t]{2}{*}{ Mass, $\mu \mathrm{g}$} & Conc., $\mu \mathrm{g} / \mathrm{g}$ & \multirow{2}{*}{$\frac{\text { Mass, } \mu \mathrm{g}}{[7]}$} & & & & & \\
\hline$\overline{\mathrm{Ag}}$ & & & Conc., $\mu \mathrm{g} / \mathrm{g}$ & & {$[48]$} & & {$[7]$} & (a) & {$[6]$} & & \\
\hline $\mathrm{Al}$ & 3729 & 393569 & 178 & 15379 & 122800 & 17560 & 426508 & $96 \%$ & 365788 & 325000 & $113 \%$ \\
\hline As & & & & & & & & & & & \\
\hline B & & & & & [200] & [29] & [29] & (a) & [25] & [135] & $18 \%$ \\
\hline $\mathrm{Ba}$ & & & & & 1300 & 186 & 186 & (a) & 159 & [110] & $145 \%$ \\
\hline $\mathrm{Be}$ & & & & & & & & & & & \\
\hline $\mathrm{Bi}$ & & & & & 4650 & 665 & 665 & (a) & 570 & 1365 & $42 \%$ \\
\hline $\mathrm{Ca}$ & [11] & [1110] & [5] & [398] & 9570 & 1369 & 2876 & $52 \%$ & 2467 & {$[1200]$} & $206 \%$ \\
\hline $\mathrm{Cd}$ & & & & & 318 & 45 & 45 & (a) & 39 & {$[60]$} & $65 \%$ \\
\hline $\mathrm{Ce}$ & & & & & [1200] & {$[172]$} & [172] & (a) & [147] & & \\
\hline Co & & & & & {$[120]$} & {$[17]$} & {$[17]$} & (a) & [15] & & \\
\hline $\mathrm{Cr}$ & 235 & 24781 & 11 & 981 & 20558 & 2940 & 28702 & $90 \%$ & 24616 & 23050 & $107 \%$ \\
\hline $\mathrm{Cu}$ & & & & & & & & & & {$[82]$} & $0 \%$ \\
\hline Dy & & & & & & & & & & & \\
\hline $\mathrm{Eu}$ & & & & & & & & & & & \\
\hline $\mathrm{Fe}$ & [15] & [1628] & & & 105830 & 15134 & 16762 & $10 \%$ & 14375 & 14150 & $102 \%$ \\
\hline $\mathrm{K}$ & & & & & N/A & N/A & N/A & N/A & N/A & N/A & N/A \\
\hline $\mathrm{La}$ & & & & & 1340 & 192 & 192 & (a) & 164 & [160] & $103 \%$ \\
\hline $\mathrm{Li}$ & & & & & [120] & [17] & [17] & (a) & [15] & & \\
\hline $\mathrm{Mg}$ & & & & & 2740 & 392 & 392 & (a) & 336 & [380] & $88 \%$ \\
\hline $\mathrm{Mn}$ & & & & & 46800 & 6692 & 6692 & (a) & 5740 & 5305 & $108 \%$ \\
\hline Mo & & & & & & & & & & & \\
\hline $\mathrm{Na}$ & 92604 & 9774048 & 4953 & 428235 & 40900 & 5849 & 10208131 & N/A & N/A & $\mathrm{N} / \mathrm{A}$ & $\mathrm{N} / \mathrm{A}$ \\
\hline $\mathrm{Nd}$ & & & & & 1950 & 279 & 279 & (a) & 239 & [345] & $69 \%$ \\
\hline $\mathrm{Ni}$ & [1] & [107] & [1] & [53] & N/A & N/A & N/A & N/A & N/A & N/A & $\mathrm{N} / \mathrm{A}$ \\
\hline $\mathrm{P}$ & [17] & [1774] & [0] & {$[0]$} & {$[180]$} & [26] & [1800] & $99 \%$ & [1544] & 1415 & $109 \%$ \\
\hline $\mathrm{Pb}$ & [5] & [532] & & & 700 & 100 & 632 & $84 \%$ & 542 & [595] & $91 \%$ \\
\hline $\mathrm{Pd}$ & & & & & & & & & & & \\
\hline $\mathrm{Rh}$ & & & & & & & & & & & \\
\hline $\mathrm{Ru}$ & & & & & & & & & & & \\
\hline $\mathrm{Sb}$ & & & & & & & & & & & \\
\hline $\mathrm{Se}$ & & & & & & & & & & & \\
\hline $\mathrm{Si}$ & [61] & [6408] & [20] & [1724] & 6520 & 932 & 9064 & $90 \%$ & 7773 & {$[5500]$} & $141 \%$ \\
\hline Sn & & & & & & & & & & & \\
\hline $\mathrm{Sr}$ & & & & & 11200 & 1602 & 1602 & (a) & 1374 & 1240 & $111 \%$ \\
\hline $\mathrm{Te}$ & & & & & & & & & & & \\
\hline Th & & & & & & & & & & & \\
\hline $\mathrm{Ti}$ & & & & & 322 & 46 & 46 & (a) & 39 & [58] & $68 \%$ \\
\hline $\mathrm{Tl}$ & & & & & & & & & & & \\
\hline U & & & & & 168800 & 24138 & 24138 & (a) & 20702 & [23500] & $88 \%$ \\
\hline $\mathrm{V}$ & & & & & & & & & & & \\
\hline W & & & & & & & & & & & \\
\hline Y & & & & & [290] & [41] & [41] & (a) & [36] & & \\
\hline $\mathrm{Zn}$ & [2] & [253] & & & 555 & 79 & 333 & $76 \%$ & 285 & [225] & $127 \%$ \\
\hline $\mathrm{Zr}$ & & & & & 1270 & 182 & 182 & (a) & 156 & [135] & $115 \%$ \\
\hline
\end{tabular}


Table B.7. Results of Leaching S- 110 Sludge With $1 \mathrm{M} \mathrm{NaOH}$ At $100^{\circ} \mathrm{C}$

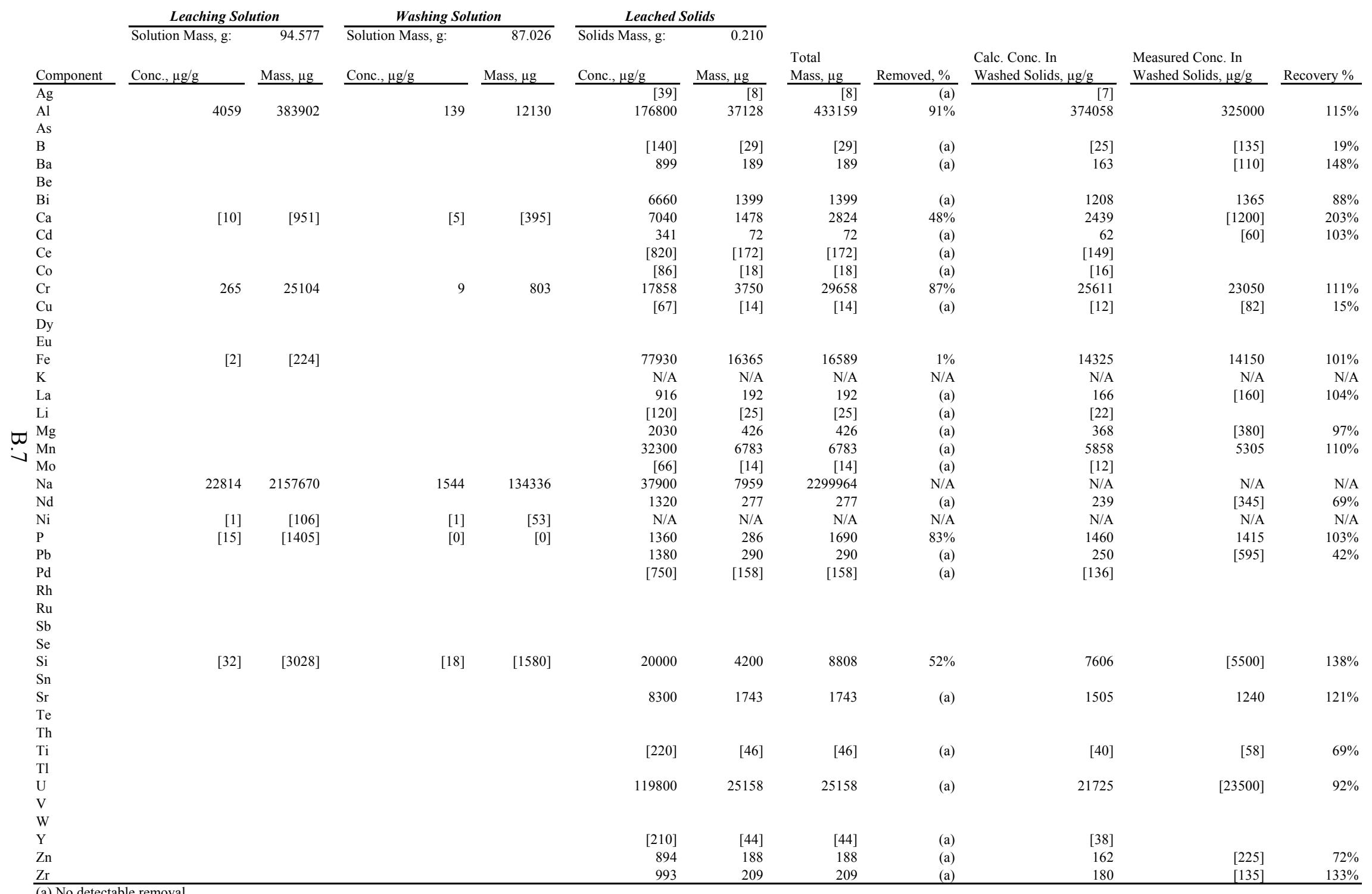

(a) No detectable removal. 
Table B.8. Results of Leaching S- 110 Sludge With $3 \mathrm{M} \mathrm{NaOH}$ At $100^{\circ} \mathrm{C}$

\begin{tabular}{|c|c|c|c|c|c|c|c|c|c|c|c|}
\hline \multirow[b]{3}{*}{ Component } & \multicolumn{2}{|c|}{ Leaching Solution } & \multicolumn{2}{|c|}{ Washing Solution } & \multicolumn{2}{|c|}{ Leached Solids } & \multirow[b]{3}{*}{ Total } & \multirow[b]{3}{*}{ Removed, \% } & \multirow[b]{3}{*}{$\begin{array}{l}\text { Calc. Conc. In } \\
\text { Washed Solids, } \mu \mathrm{g} / \mathrm{g}\end{array}$} & \multirow[b]{3}{*}{$\begin{array}{l}\text { Measured Conc. In } \\
\text { Washed Solids, } \mu \mathrm{g} / \mathrm{g}\end{array}$} & \multirow[b]{3}{*}{ Recovery \% } \\
\hline & \multirow{2}{*}{$\begin{array}{l}\text { Solution Mass, g: } \\
\text { Conc., } \mu \mathrm{g} / \mathrm{g}\end{array}$} & \multirow{2}{*}{$\begin{array}{r}99.957 \\
\text { Mass, } \mu \mathrm{g}\end{array}$} & Solution Mass, g: & 84.813 & Solids Mass, g: & 0.107 & & & & & \\
\hline & & & Conc., $\mu \mathrm{g} / \mathrm{g}$ & \multirow{2}{*}{ Mass, $\mu \mathrm{g}$} & Conc., $\mu \mathrm{g} / \mathrm{g}$ & Mass, $\mu \mathrm{g}$ & & & & & \\
\hline $\mathrm{Ag}$ & & & & & {$[66]$} & {$[7]$} & {$[7]$} & (a) & {$[6]$} & & \\
\hline $\mathrm{Al}$ & 4158 & 415665 & 9 & 762 & 13100 & 1402 & 417829 & $100 \%$ & 356205 & 325000 & $110 \%$ \\
\hline \multicolumn{12}{|l|}{ As } \\
\hline B & & & & & 546 & 58 & 58 & (a) & 50 & [135] & $37 \%$ \\
\hline $\mathrm{Ba}$ & & & & & 1620 & 173 & 173 & (a) & 148 & [110] & $134 \%$ \\
\hline \multicolumn{12}{|l|}{$\mathrm{Be}$} \\
\hline $\mathrm{Bi}$ & & & & & 8240 & 882 & 882 & (a) & 752 & 1365 & $55 \%$ \\
\hline $\mathrm{Ca}$ & & & & & 11970 & 1281 & 1281 & (a) & 1092 & [1200] & $91 \%$ \\
\hline $\mathrm{Cd}$ & & & & & 498 & 53 & 53 & (a) & 45 & [60] & $76 \%$ \\
\hline $\mathrm{Ce}$ & & & & & [1400] & [150] & {$[150]$} & (a) & [128] & & \\
\hline Co & & & & & {$[140]$} & {$[15]$} & {$[15]$} & (a) & [13] & & \\
\hline $\mathrm{Cr}$ & 264 & 26425 & 1 & 49 & 24858 & 2660 & 29134 & $91 \%$ & 24837 & 23050 & $108 \%$ \\
\hline $\mathrm{Cu}$ & & & & & [37] & [4] & [4] & (a) & [3] & [82] & $4 \%$ \\
\hline \multicolumn{12}{|l|}{ Dy } \\
\hline \multicolumn{12}{|l|}{$\mathrm{Eu}$} \\
\hline $\mathrm{Fe}$ & [8] & [759] & & & 139830 & 14962 & 15721 & $5 \%$ & 13402 & 14150 & $95 \%$ \\
\hline $\mathrm{K}$ & & & & & N/A & N/A & $\mathrm{N} / \mathrm{A}$ & $\mathrm{N} / \mathrm{A}$ & N/A & N/A & $\mathrm{N} / \mathrm{A}$ \\
\hline $\mathrm{La}$ & & & & & 1680 & 180 & 180 & (a) & 153 & [160] & $96 \%$ \\
\hline $\mathrm{Li}$ & & & & & [180] & [19] & [19] & (a) & [16] & & \\
\hline $\mathrm{Mg}$ & & & & & 3730 & 399 & 399 & (a) & 340 & [380] & $90 \%$ \\
\hline Mn & & & & & 57400 & 6142 & 6142 & (a) & 5236 & 5305 & $99 \%$ \\
\hline Mo & & & & & [58] & {$[6]$} & [6] & (a) & [5] & & \\
\hline $\mathrm{Na}$ & 60028 & 6000174 & 160 & 13570 & 62900 & 6730 & 6020474 & N/A & $\mathrm{N} / \mathrm{A}$ & N/A & N/A \\
\hline $\mathrm{Nd}$ & & & & & 2470 & 264 & 264 & (a) & 225 & [345] & $65 \%$ \\
\hline $\mathrm{Ni}$ & [1] & {$[141]$} & & & N/A & N/A & N/A & N/A & N/A & N/A & N/A \\
\hline$P$ & {$[18]$} & [1798] & & & [770] & [82] & [1881] & $96 \%$ & {$[1603]$} & 1415 & $113 \%$ \\
\hline $\mathrm{Pb}$ & [6] & [596] & & & 1480 & 158 & 755 & $79 \%$ & 643 & [595] & $108 \%$ \\
\hline $\mathrm{Pd}$ & & & & & [1200] & [128] & [128] & (a) & [109] & & \\
\hline \multirow{2}{*}{\multicolumn{12}{|c|}{$\begin{array}{l}\mathrm{Rh} \\
\mathrm{Ru}\end{array}$}} \\
\hline & & & & & & & & & & & \\
\hline \multicolumn{12}{|l|}{$\mathrm{Sb}$} \\
\hline $\mathrm{Se}$ & & & & & & & & & & & \\
\hline $\mathrm{Si}$ & [63] & {$[6318]$} & [1] & [110] & 11800 & 1263 & 7691 & $84 \%$ & 6556 & {$[5500]$} & $119 \%$ \\
\hline Sn & & & & & & & & & & & \\
\hline $\mathrm{Sr}$ & & & & & 14500 & 1552 & 1552 & (a) & 1323 & 1240 & $107 \%$ \\
\hline $\mathrm{Te}$ & & & & & & & & & & & \\
\hline Th & & & & & {$[1300]$} & [139] & [139] & (a) & [119] & & \\
\hline $\mathrm{Ti}$ & & & & & 392 & 42 & 42 & (a) & 36 & [58] & $62 \%$ \\
\hline $\mathrm{Tl}$ & & & & & & & & & & & \\
\hline $\mathrm{U}$ & & & & & 217800 & 23305 & 23305 & (a) & 19868 & {$[23500]$} & $85 \%$ \\
\hline V & & & & & {$[68]$} & [7] & [7] & (a) & [6] & & \\
\hline W & & & & & & & & & & & \\
\hline Y & & & & & [370] & [40] & [40] & (a) & [34] & & \\
\hline $\mathrm{Zn}$ & [2] & [245] & & & 753 & 81 & 326 & $75 \%$ & 278 & [225] & $123 \%$ \\
\hline $\mathrm{Zr}$ & & & & & 1720 & 184 & 184 & (a) & 157 & [135] & $116 \%$ \\
\hline
\end{tabular}

(a) No detectable removal. 
Table B.9. Results of Leaching S- 110 Sludge With $5 \mathrm{M} \mathrm{NaOH}$ At $100^{\circ} \mathrm{C}$

\begin{tabular}{|c|c|c|c|c|c|c|c|c|c|c|c|}
\hline \multirow[b]{3}{*}{ Component } & \multicolumn{2}{|c|}{ Leaching Solution } & \multicolumn{2}{|c|}{ Washing Solution } & \multicolumn{2}{|c|}{ Leached Solids } & \multirow[b]{3}{*}{ Total } & \multirow[b]{3}{*}{ Removed, \% } & \multirow[b]{3}{*}{$\begin{array}{l}\text { Calc. Conc. In } \\
\text { Washed Solids, } \mu \mathrm{g} / \mathrm{g}\end{array}$} & \multirow[b]{3}{*}{$\begin{array}{l}\text { Measured Conc. In } \\
\text { Washed Solids, } \mu \mathrm{g} / \mathrm{g}\end{array}$} & \multirow[b]{3}{*}{ Recovery \% } \\
\hline & \multirow{2}{*}{$\begin{array}{l}\text { Solution Mass, g: } \\
\text { Conc., } \mu \mathrm{g} / \mathrm{g}\end{array}$} & \multirow{2}{*}{$\begin{array}{r}106.523 \\
\text { Mass, } \mu \mathrm{g}\end{array}$} & \multirow{2}{*}{$\begin{array}{l}\text { Solution Mass, g: } \\
\text { Conc., } \mu \mathrm{g} / \mathrm{g}\end{array}$} & \multirow{2}{*}{$\begin{array}{l}88.233 \\
\text { Mass, } \mu \mathrm{g}\end{array}$} & \multirow{2}{*}{$\begin{array}{l}\text { Solids Mass, g: } \\
\text { Conc., } \mu \mathrm{g} / \mathrm{g}\end{array}$} & $\overline{0.099}$ & & & & & \\
\hline & & & & & & Mass, $\mu \mathrm{g}$ & & & & & \\
\hline $\mathrm{Ag}$ & & & & & {$[73]$} & {$[7]$} & {$[7]$} & (a) & {$[6]$} & & \\
\hline $\mathrm{Al}$ & 3967 & 422563 & 134 & 11862 & 8840 & 875 & 435301 & $100 \%$ & 373328 & 325000 & $115 \%$ \\
\hline \multicolumn{12}{|l|}{ As } \\
\hline B & & & & & [380] & [38] & [38] & (a) & [32] & [135] & $24 \%$ \\
\hline $\mathrm{Ba}$ & & & & & 1750 & 173 & 173 & (a) & 149 & [110] & $135 \%$ \\
\hline \multicolumn{12}{|l|}{$\mathrm{Be}$} \\
\hline $\mathrm{Bi}$ & & & & & 5440 & 539 & 539 & (a) & 462 & 1365 & $34 \%$ \\
\hline $\mathrm{Ca}$ & [10] & [1050] & [6] & [562] & 12670 & 1254 & 2865 & $56 \%$ & 2458 & {$[1200]$} & $205 \%$ \\
\hline $\mathrm{Cd}$ & & & & & 355 & 35 & 35 & (a) & 30 & {$[60]$} & $50 \%$ \\
\hline $\mathrm{Ce}$ & & & & & [1500] & [149] & [149] & (a) & [127] & & \\
\hline Co & & & & & {$[160]$} & [16] & {$[16]$} & (a) & [14] & & \\
\hline $\mathrm{Cr}$ & 255 & 27203 & 9 & 781 & 22358 & 2213 & 30197 & $93 \%$ & 25898 & 23050 & $112 \%$ \\
\hline \multirow{2}{*}{\multicolumn{12}{|c|}{$\begin{array}{l}\mathrm{Cu} \\
\mathrm{Dy}\end{array}$}} \\
\hline & & & & & & & & & & & \\
\hline \multicolumn{12}{|l|}{$\mathrm{Eu}$} \\
\hline $\mathrm{Fe}$ & [17] & [1758] & & & 144830 & 14338 & 16096 & $11 \%$ & 13805 & 14150 & $98 \%$ \\
\hline $\mathrm{K}$ & & & & & N/A & N/A & N/A & N/A & N/A & N/A & N/A \\
\hline $\mathrm{La}$ & & & & & 1780 & 176 & 176 & (a) & 151 & [160] & $94 \%$ \\
\hline $\mathrm{Li}$ & & & & & [140] & [14] & [14] & (a) & [12] & & \\
\hline $\mathrm{Mg}$ & & & & & 3960 & 392 & 392 & (a) & 336 & [380] & $88 \%$ \\
\hline $\mathrm{Mn}$ & & & & & 61200 & 6059 & 6059 & (a) & 5196 & 5305 & $98 \%$ \\
\hline Mo & & & & & & & & & & & \\
\hline $\mathrm{Na}$ & 98205 & 10461099 & 3757 & 331485 & 67900 & 6722 & 10799306 & N/A & N/A & N/A & N/A \\
\hline $\mathrm{Nd}$ & & & & & 2590 & 256 & 256 & (a) & 220 & [345] & $64 \%$ \\
\hline $\mathrm{Ni}$ & [2] & [246] & [1] & [110] & N/A & $\mathrm{N} / \mathrm{A}$ & N/A & N/A & N/A & N/A & N/A \\
\hline $\mathrm{P}$ & [18] & [1927] & & & {$[250]$} & [25] & [1951] & $99 \%$ & {$[1674]$} & 1415 & $118 \%$ \\
\hline $\mathrm{Pb}$ & [6] & {$[672]$} & & & 1010 & 100 & 772 & $87 \%$ & 662 & [595] & $111 \%$ \\
\hline $\mathrm{Pd}$ & & & & & & & & & & & \\
\hline $\mathrm{Rh}$ & & & & & & & & & & & \\
\hline $\mathrm{Ru}$ & & & & & & & & & & & \\
\hline $\mathrm{Sb}$ & & & & & & & & & & & \\
\hline $\mathrm{Se}$ & & & & & & & & & & & \\
\hline $\mathrm{Si}$ & [64] & [6869] & [22] & [1918] & 9450 & 936 & 9722 & $90 \%$ & 8338 & [5500] & $152 \%$ \\
\hline Sn & & & & & & & & & & & \\
\hline $\mathrm{Sr}$ & & & & & 15400 & 1525 & 1525 & (a) & 1308 & 1240 & $105 \%$ \\
\hline $\mathrm{Te}$ & & & & & & & & & & & \\
\hline Th & & & & & & & & & & & \\
\hline $\mathrm{Ti}$ & & & & & 427 & 42 & 42 & (a) & 36 & [58] & $63 \%$ \\
\hline $\mathrm{Tl}$ & & & & & & & & & & & \\
\hline U & & & & & 232800 & 23047 & 23047 & (a) & 19766 & [23500] & $84 \%$ \\
\hline V & & & & & & & & & & & \\
\hline W & & & & & & & & & & & \\
\hline Y & & & & & [380] & [38] & [38] & (a) & [32] & & \\
\hline $\mathrm{Zn}$ & [3] & [298] & & & 450 & 45 & 343 & $87 \%$ & 294 & [225] & $131 \%$ \\
\hline $\mathrm{Zr}$ & & & & & 1740 & 172 & 172 & (a) & 148 & [135] & $109 \%$ \\
\hline
\end{tabular}





\section{Appendix C}

\section{Radionuclide Behavior}





\section{Appendix C: Radionuclide Behavior}

Table C.1. Radionuclide Behavior During Leaching of S-110 Solids at $60^{\circ} \mathrm{C}^{(\mathrm{a})}$

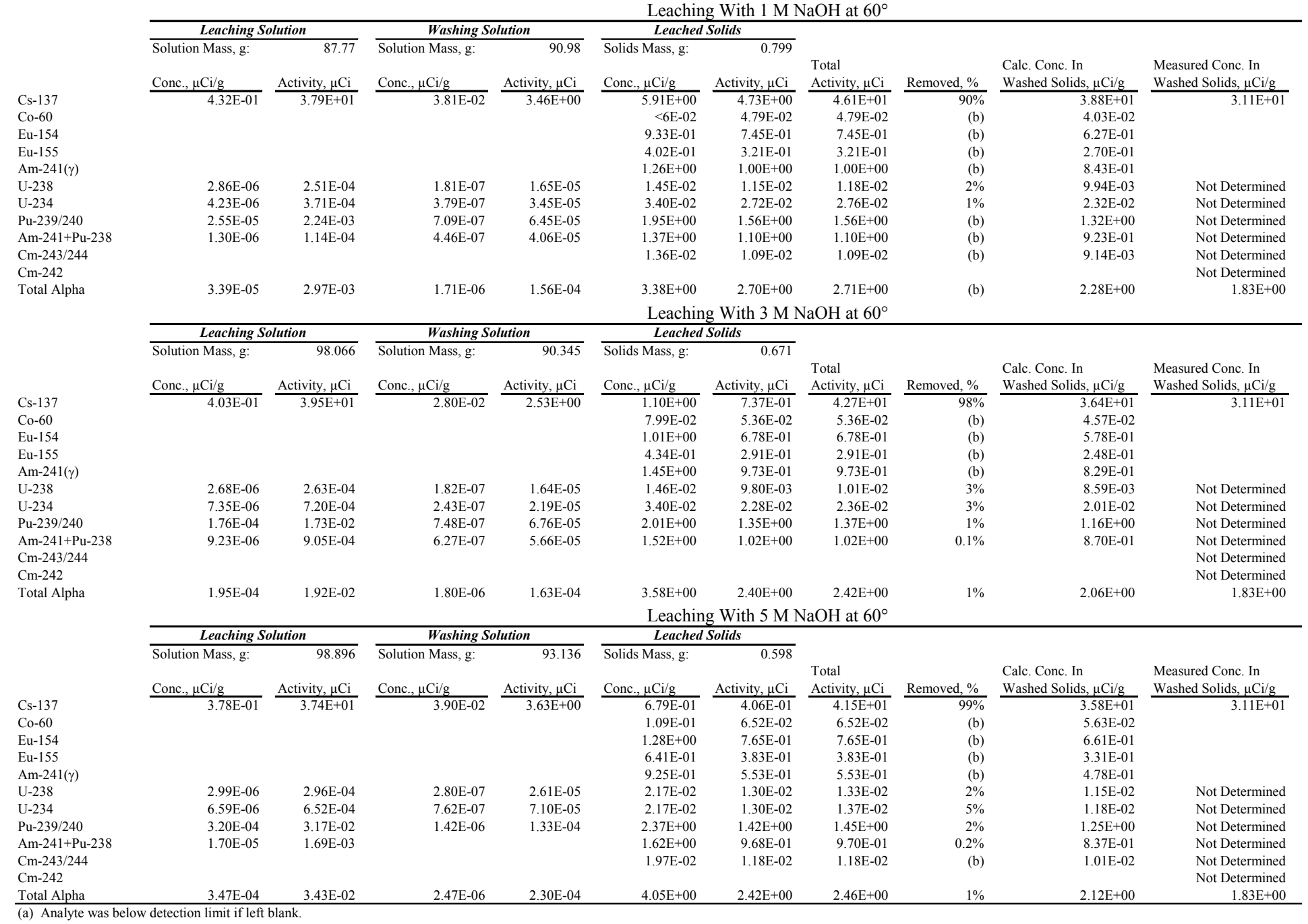

(a) Analyte was below detecto
(b) No detectable removal. 
Table C.2. Radionuclide Behavior During Leaching of S-110 Solids at $80^{\circ} \mathrm{C}^{(\mathrm{a})}$

\begin{tabular}{|c|c|c|c|c|c|c|c|c|c|c|}
\hline & \multicolumn{10}{|c|}{ Leaching With $1 \mathrm{M} \mathrm{NaOH}$ at $80^{\circ}$} \\
\hline & \multicolumn{2}{|c|}{ Leaching Solution } & \multicolumn{2}{|c|}{ Washing Solution } & \multicolumn{2}{|c|}{ Leached Solids } & \multirow{2}{*}{ Total } & \multirow[b]{3}{*}{ Removed \% } & \multirow{3}{*}{$\begin{array}{l}\text { Calc. Conc. In } \\
\text { Washed Solids, } \mu \mathrm{Ci} / \mathrm{g}\end{array}$} & \multirow{3}{*}{$\begin{array}{l}\text { Measured Conc. In } \\
\text { Washed Solids, } \mu \mathrm{Ci} / \mathrm{g}\end{array}$} \\
\hline & Solution Mass, g: & 90.105 & Solution Mass, g: & 86.262 & Solids Mass, g: & 0.423 & & & & \\
\hline & Conc., $\mu \mathrm{Ci} / \mathrm{g}$ & Activity, $\mu \mathrm{Ci}$ & Conc., $\mu \mathrm{Ci} / \mathrm{g}$ & Activity $\mu \mathrm{Ci}$ & Conc., $\mu \mathrm{Ci} / \mathrm{g}$ & Activity $\mu \mathrm{Ci}$ & $\begin{array}{l}\text { Total } \\
\text { Activity, } \mu \mathrm{Ci}\end{array}$ & & & \\
\hline Cs-137 & $4.38 \mathrm{E}-01$ & $3.95 \mathrm{E}+01$ & $1.69 \mathrm{E}-02$ & $1.46 \mathrm{E}+00$ & $9.76 \mathrm{E}+00$ & $4.13 \mathrm{E}+00$ & $4.50 \mathrm{E}+01$ & $91 \%$ & $3.86 \mathrm{E}+01$ & \\
\hline Co- 60 & & & & & $1.25 \mathrm{E}-01$ & $5.29 \mathrm{E}-02$ & $5.29 \mathrm{E}-02$ & (b) & 4.53E- 02 & \\
\hline Eu-154 & & & & & $1.75 \mathrm{E}+00$ & $7.40 \mathrm{E}-01$ & $7.40 \mathrm{E}-01$ & (b) & $6.35 \mathrm{E}-01$ & \\
\hline Eu-155 & & & & & $1.04 \mathrm{E}+00$ & $4.40 \mathrm{E}-01$ & $4.40 \mathrm{E}-01$ & (b) & $3.77 \mathrm{E}-01$ & \\
\hline 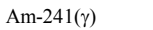 & & & & & $2.35 \mathrm{E}+00$ & $9.94 \mathrm{E}-01$ & $9.94 \mathrm{E}-01$ & (b) & $8.53 \mathrm{E}-01$ & \\
\hline $\mathrm{U}-238$ & $2.57 \mathrm{E}-06$ & $2.32 \mathrm{E}-04$ & $1.14 \mathrm{E}-07$ & $9.82 \mathrm{E}-06$ & $2.52 \mathrm{E}-02$ & $1.07 \mathrm{E}-02$ & $1.09 \mathrm{E}-02$ & $2 \%$ & $9.35 \mathrm{E}-03$ & Not Determined \\
\hline $\mathrm{U}-234$ & 4.68E-06 & $4.22 \mathrm{E}-04$ & $2.56 \mathrm{E}-07$ & $2.21 \mathrm{E}-05$ & 4.34E-02 & $1.84 \mathrm{E}-02$ & $1.88 \mathrm{E}-02$ & $2 \%$ & $1.61 \mathrm{E}-02$ & Not Determined \\
\hline Pu-239/240 & $1.67 \mathrm{E}-05$ & $1.51 \mathrm{E}-03$ & & & $3.46 \mathrm{E}+00$ & $1.46 \mathrm{E}+00$ & $1.46 \mathrm{E}+00$ & $0.1 \%$ & $1.26 \mathrm{E}+00$ & Not Determined \\
\hline Am-241+Pu-238 & $1.66 \mathrm{E}-06$ & $1.50 \mathrm{E}-04$ & & & $2.43 \mathrm{E}+00$ & $1.03 \mathrm{E}+00$ & $1.03 \mathrm{E}+00$ & $0.01 \%$ & $8.81 \mathrm{E}-01$ & Not Determined \\
\hline $\mathrm{Cm}-243 / 244$ & & & & & $2.07 \mathrm{E}-02$ & $8.74 \mathrm{E}-03$ & $8.74 \mathrm{E}-03$ & (b) & $7.49 \mathrm{E}-03$ & Not Determined \\
\hline $\mathrm{Cm}-242$ & & & & & $5.05 \mathrm{E}-03$ & $2.14 \mathrm{E}-03$ & $2.14 \mathrm{E}-03$ & (b) & $1.83 \mathrm{E}-03$ & Not Determined \\
\hline \multirow[t]{6}{*}{ Total Alpha } & $2.56 \mathrm{E}-05$ & $2.31 \mathrm{E}-03$ & & & $5.98 \mathrm{E}+00$ & $2.53 \mathrm{E}+00$ & $2.53 \mathrm{E}+00$ & $0.09 \%$ & $2.17 \mathrm{E}+00$ & $1.83 \mathrm{E}+00$ \\
\hline & \multicolumn{10}{|c|}{ Leaching With $3 \mathrm{M} \mathrm{NaOH}$ at $80^{\circ}$} \\
\hline & \multicolumn{2}{|c|}{ Leaching Solution } & \multicolumn{2}{|c|}{ Washing Solution } & \multicolumn{2}{|c|}{ Leached Solids } & & & & \\
\hline & Solution Mass, g: & 99.177 & Solution Mass, g: & 87.325 & Solids Mass, g: & 0.207 & & & & \\
\hline & & & & & & & Total & & Calc. Conc. In & Measured Conc. In \\
\hline & Conc., $\mu \mathrm{Ci} / \mathrm{g}$ & Activity, $\mu \mathrm{Ci}$ & 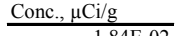 & $\frac{\text { Activity, } \mu \mathrm{Ci}}{160 \mathrm{P} 0}$ & Conc., $\mu \mathrm{Ci} / \mathrm{g}$ & $\frac{\text { Activity, } \mu \mathrm{Ci}}{\sigma_{150}}$ & Activity, $\mu \mathrm{Ci}$ & Removed, \% & $\underline{\text { Washed Solids, } \mu \mathrm{Ci} / \mathrm{g}}$ & Washed Solids, $\mu \mathrm{Ci} / \mathrm{g}$ \\
\hline Cs-137 & $4.19 \mathrm{E}-01$ & $4.16 \mathrm{E}+01$ & $1.84 \mathrm{E}-02$ & $1.60 \mathrm{E}+00$ & $2.49 \mathrm{E}+00$ & $5.15 \mathrm{E}-01$ & $4.37 \mathrm{E}+01$ & $99 \%$ & $3.77 \mathrm{E}+01$ & $3.11 \mathrm{E}+01$ \\
\hline Сo- 60 & & & & & $2.78 \mathrm{E}-01$ & $5.75 \mathrm{E}-02$ & $5.75 \mathrm{E}-02$ & (b) & $4.97 \mathrm{E}-02$ & \\
\hline Eu-154 & & & & & $3.50 \mathrm{E}+00$ & $7.25 \mathrm{E}-01$ & $7.25 \mathrm{E}-01$ & (b) & $6.26 \mathrm{E}-01$ & \\
\hline Eu-155 & & & & & $1.79 \mathrm{E}+00$ & $3.71 \mathrm{E}-01$ & $3.71 \mathrm{E}-01$ & (b) & $3.20 \mathrm{E}-01$ & \\
\hline $\mathrm{Am}-241(\gamma)$ & & & & & $4.16 \mathrm{E}+00$ & $8.61 \mathrm{E}-01$ & $8.61 \mathrm{E}-01$ & (b) & 7.44E-01 & \\
\hline $\mathrm{U}-238$ & $3.32 \mathrm{E}-06$ & $3.29 \mathrm{E}-04$ & $2.64 \mathrm{E}-07$ & $2.31 \mathrm{E}-05$ & $4.02 \mathrm{E}-02$ & $8.32 \mathrm{E}-03$ & $8.67 \mathrm{E}-03$ & $4 \%$ & $7.49 \mathrm{E}-03$ & Not Determined \\
\hline U-234 & $6.08 \mathrm{E}-06$ & $6.03 \mathrm{E}-04$ & $4.34 \mathrm{E}-07$ & $3.79 \mathrm{E}-05$ & $6.93 \mathrm{E}-02$ & $1.43 \mathrm{E}-02$ & $1.50 \mathrm{E}-02$ & $4 \%$ & $1.29 \mathrm{E}-02$ & Not Determined \\
\hline Pu-239/240 & $9.26 \mathrm{E}-05$ & $9.18 \mathrm{E}-03$ & $4.03 \mathrm{E}-07$ & $3.52 \mathrm{E}-05$ & $6.67 \mathrm{E}+00$ & $1.38 \mathrm{E}+00$ & $1.39 \mathrm{E}+00$ & $1 \%$ & $1.20 \mathrm{E}+00$ & Not Determined \\
\hline Am-241+Pu-238 & 4.53E-06 & $4.49 \mathrm{E}-04$ & $7.76 \mathrm{E}-08$ & $6.78 \mathrm{E}-06$ & $4.66 \mathrm{E}+00$ & $9.64 \mathrm{E}-01$ & $9.65 \mathrm{E}-01$ & $0.05 \%$ & $8.33 \mathrm{E}-01$ & Not Determined \\
\hline $\mathrm{Cm}-243 / 244$ & & & & & $6.73 \mathrm{E}-02$ & $1.39 \mathrm{E}-02$ & $1.39 \mathrm{E}-02$ & (b) & $1.20 \mathrm{E}-02$ & Not Determined \\
\hline $\mathrm{Cm}-242$ & & & & & $6.11 \mathrm{E}-03$ & $1.26 \mathrm{E}-03$ & $1.26 \mathrm{E}-03$ & (b) & $1.09 \mathrm{E}-03$ & Not Determined \\
\hline \multirow{6}{*}{ Total Alpha } & $1.07 \mathrm{E}-04$ & $1.06 \mathrm{E}-02$ & $1.18 \mathrm{E}-06$ & $1.03 \mathrm{E}-04$ & $1.15 \mathrm{E}+01$ & $2.38 \mathrm{E}+00$ & $2.39 \mathrm{E}+00$ & $0.4 \%$ & $2.06 \mathrm{E}+00$ & $1.83 \mathrm{E}+00$ \\
\hline & \multicolumn{9}{|c|}{ Leaching With $5 \mathrm{M} \mathrm{NaOH}$ at $80^{\circ}$} & \\
\hline & \multicolumn{2}{|c|}{ Leaching Solution } & \multicolumn{2}{|c|}{ Washing Solution } & \multicolumn{2}{|c|}{ Leached Solids } & & & & \\
\hline & Solution Mass, g: & 105.547 & Solution Mass, g: & 86.46 & Solids Mass, g: & 0.143 & & & & \\
\hline & & & & & & & Total & & Calc. Conc. In & Measured Conc. In \\
\hline & Conc., $\mu \mathrm{Ci} / \mathrm{g}$ & Activity, $\mu \mathrm{Ci}$ & Conc., $\mu \mathrm{Ci} / \mathrm{g}$ & Activity, $\mu \mathrm{Ci}$ & Conc., $\mu \mathrm{Ci} / \mathrm{g}$ & Activity, $\mu \mathrm{Ci}$ & Activity, $\mu \mathrm{Ci}$ & Removed, \% & Washed Solids, $\mu \mathrm{Ci} / \mathrm{g}$ & Washed Solids, $\mu \mathrm{Ci} / \mathrm{g}$ \\
\hline Cs-137 & $3.81 \mathrm{E}-01$ & $4.02 \mathrm{E}+01$ & $1.80 \mathrm{E}-02$ & $1.56 \mathrm{E}+00$ & $1.09 \mathrm{E}+00$ & $1.56 \mathrm{E}-01$ & $4.19 \mathrm{E}+01$ & $100 \%$ & $3.59 \mathrm{E}+01$ & $3.11 \mathrm{E}+01$ \\
\hline Co- 60 & & & & & $3.81 \mathrm{E}-01$ & $5.45 \mathrm{E}-02$ & $5.45 \mathrm{E}-02$ & (b) & 4.67E-02 & \\
\hline Eu-154 & & & & & $5.38 \mathrm{E}+00$ & $7.69 \mathrm{E}-01$ & $7.69 \mathrm{E}-01$ & (b) & $6.60 \mathrm{E}-01$ & \\
\hline Eu-155 & & & & & $2.75 \mathrm{E}+00$ & $3.93 \mathrm{E}-01$ & $3.93 \mathrm{E}-01$ & (b) & 3.37E-01 & \\
\hline $\mathrm{Am}-241(\gamma)$ & & & & & $6.38 \mathrm{E}+00$ & $9.12 \mathrm{E}-01$ & $9.12 \mathrm{E}-01$ & (b) & 7.82E-01 & \\
\hline $\mathrm{U}-238$ & $2.08 \mathrm{E}-06$ & $2.19 \mathrm{E}-04$ & $1.19 \mathrm{E}-07$ & $1.03 \mathrm{E}-05$ & $6.30 \mathrm{E}-02$ & $9.01 \mathrm{E}-03$ & $9.24 \mathrm{E}-03$ & $2 \%$ & $7.92 \mathrm{E}-03$ & Not Determined \\
\hline $\mathrm{U}-234$ & 5.33E-06 & $5.63 \mathrm{E}-04$ & $3.86 \mathrm{E}-07$ & 3.33E-05 & $1.07 \mathrm{E}-01$ & $1.53 \mathrm{E}-02$ & $1.59 \mathrm{E}-02$ & $4 \%$ & $1.36 \mathrm{E}-02$ & Not Determined \\
\hline Pu-239/240 & $2.06 \mathrm{E}-04$ & $2.17 \mathrm{E}-02$ & 4.89E-07 & 4.23E-05 & $9.76 \mathrm{E}+00$ & $1.40 \mathrm{E}+00$ & $1.42 \mathrm{E}+00$ & $2 \%$ & $1.22 \mathrm{E}+00$ & Not Determined \\
\hline $\mathrm{Am}-241+\mathrm{Pu}-238$ & $1.18 \mathrm{E}-05$ & $1.24 \mathrm{E}-03$ & $1.04 \mathrm{E}-07$ & $8.98 \mathrm{E}-06$ & $7.00 \mathrm{E}+00$ & $1.00 \mathrm{E}+00$ & $1.00 \mathrm{E}+00$ & $0.1 \%$ & $8.59 \mathrm{E}-01$ & Not Determined \\
\hline $\mathrm{Cm}-243 / 244$ & & & & & $6.84 \mathrm{E}-02$ & $9.77 \mathrm{E}-03$ & $9.77 \mathrm{E}-03$ & (b) & $8.38 \mathrm{E}-03$ & Not Determined \\
\hline $\mathrm{Cm}-242$ & & & & & $1.18 \mathrm{E}-02$ & $1.69 \mathrm{E}-03$ & $1.69 \mathrm{E}-03$ & (b) & $1.45 \mathrm{E}-03$ & Not Determined \\
\hline Total Alnha & $225 \mathrm{E}-04$ & $238 \mathrm{E}-02$ & $10 \mathrm{E}-06$ & $949 \mathrm{E}-05$ & $170 \mathrm{~F}+01$ & $2435+00$ & $245 \mathrm{~F}+00$ & $1 \%$ & $211 \mathrm{E}+00$ & $183 \mathrm{E}+00$ \\
\hline
\end{tabular}

Total Alpha $\quad 2.25 \mathrm{E}-04 \quad 2.38 \mathrm{E}-02$
(a) Analyte was below detection limit if left blank.
(b) No detectable removal. 
Table C.3. Radionuclide Behavior During Leaching of S-110 Solids at $100^{\circ} \mathrm{C}^{(\mathrm{a})}$

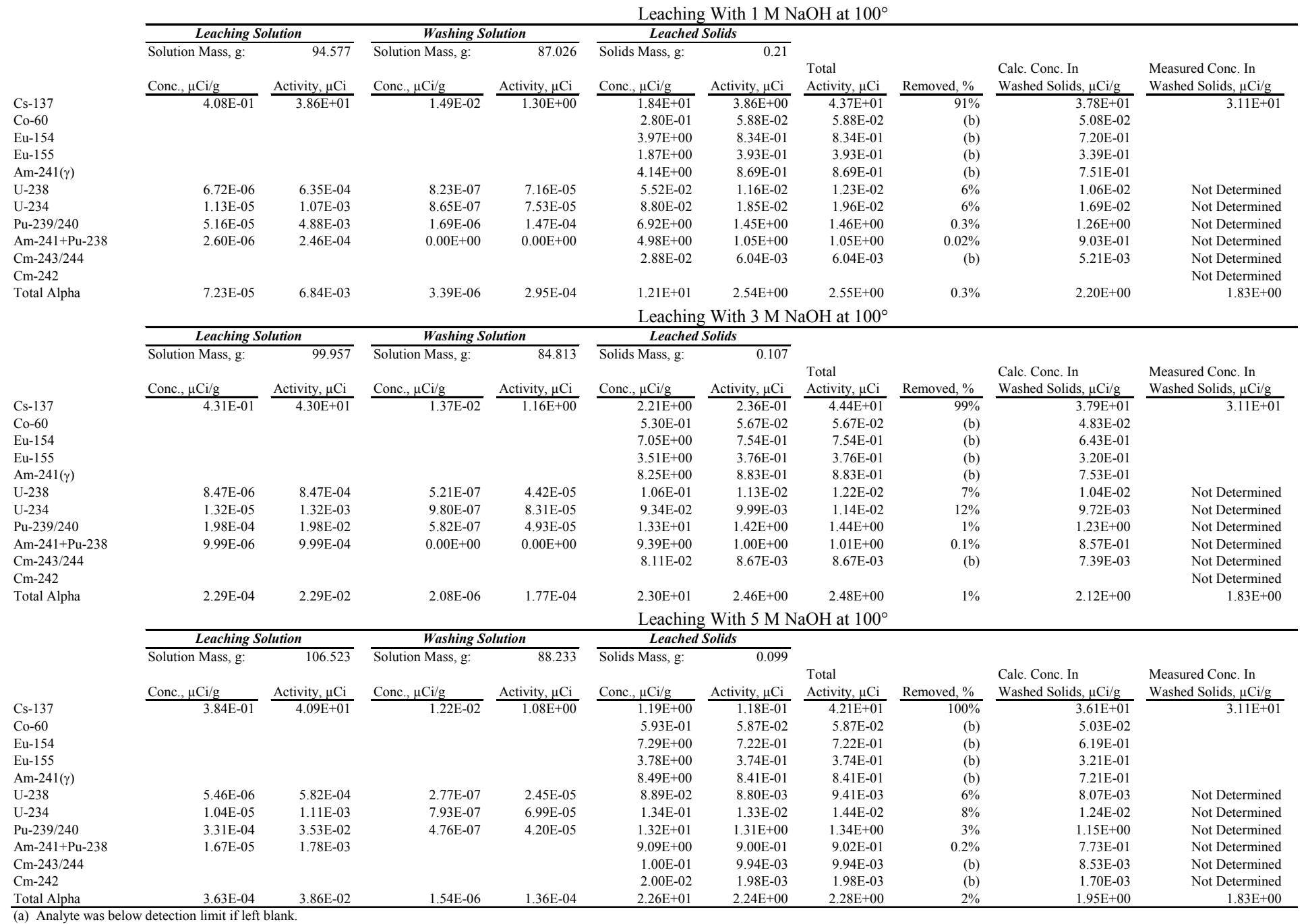

(b) No detectable removal. 


\section{Distribution}

No. of

\section{Copies}

\section{OFFSITE}

Harry Babad

2540 Cordova $\mathrm{Ct}$.

Richland, Washington 99352

Gilbert Brown

Oak Ridge National Laboratory

P.O. BOX 2008

Oak Ridge, Tennessee 37831-6119

Dale D. Ensor

Tennessee Technological University

Chemistry Department - Box 5055

Cookeville, Tennessee 38505

Kurt Gerdes

U.S. Department of Energy

Office of Technology Systems

EM-53 Cloverleaf 1186

U.S. Department of Energy

PO Box 23865

Germantown, Maryland 20026-3865

Jerry Harness

U.S. Department of Energy

Oak Ridge Operations Office

200 Administration Road

Oak Ridge, Tennessee 37830

David Hobbs

Westinghouse Savannah River Co.

773-A

Aiken, South Carolina 29808
No. of

Copies

OFFSITE

Rodney D. Hunt

Oak Ridge National Laboratory

P.O. Box 2008

Oak Ridge, Tennessee 37831-6223

Phil McGinnis

Oak Ridge National Laboratory

P.O. Box 2008

Oak Ridge, Tennessee 37831-6223

John Swanson

1318 Cottonwood

Richland, Washington

Major Thompson

Westinghouse Savannah River Co. 773-A, C140

Aiken, South Carolina 29808

Jack Watson

Oak Ridge National Laboratory

P.O. Box 2008

Oak Ridge, Tennessee 37831-6178

David Wesolowski

Oak Ridge National Laboratory

P.O. Box 2008

Oak Ridge, Tennessee 37831-6110 
No. of

Copies

ONSITE

1 Fluor Hanford Corporation

D.L. Herting

2 Numatec Hanford Corporation

R.A. Kirkbride

R.M. Orme R3-73

4 DOE Richland Operations Office

J. Cruz

M.J. Glasper

B.M. Mauss

T.P. Pietrok

3 Bechtel

R. Peterson

P. Townson

T. Wright

$2 \mathrm{CHG}$

K.A. Gasper

D.J. Washenfelder
H4-02

H4-02

H4-02

L4-07

R2-12
T6-07

No. of

Copies

\section{ONSITE}

37 Pacific Northwest National Laboratory

TFA Technical Team Office (8) K9-69

W.F. Bonner

K9-14

K.P. Brooks

K6-24

R3-73

W.C. Cosby

K7-62

J.G.H. Geeting

$\mathrm{P} 7-28$

G.R. Golcar

K6-24

D.E. Kurath

P7-28

G.J. Lumetta (20)

P7-22

B.M. Rapko

P7-25

Dist. 2 